\title{
Regional Mapping and Reservoir Analysis of the Middle Devonian Marcellus Shale in the Appalachian Basin
}

Jared VanMeter

West Virginia University

Follow this and additional works at: https://researchrepository.wvu.edu/etd

\section{Recommended Citation}

VanMeter, Jared, "Regional Mapping and Reservoir Analysis of the Middle Devonian Marcellus Shale in the Appalachian Basin" (2014). Graduate Theses, Dissertations, and Problem Reports. 634.

https://researchrepository.wvu.edu/etd/634

This Thesis is protected by copyright and/or related rights. It has been brought to you by the The Research Repository @ WVU with permission from the rights-holder(s). You are free to use this Thesis in any way that is permitted by the copyright and related rights legislation that applies to your use. For other uses you must obtain permission from the rights-holder(s) directly, unless additional rights are indicated by a Creative Commons license in the record and/ or on the work itself. This Thesis has been accepted for inclusion in WVU Graduate Theses, Dissertations, and Problem Reports collection by an authorized administrator of The Research Repository @ WVU. For more information, please contact researchrepository@mail.wvu.edu. 
Regional Mapping and Reservoir Analysis of the Middle Devonian Marcellus Shale in the Appalachian Basin

\author{
Jared VanMeter
}

Thesis submitted

to the Eberly College of Arts and Sciences

at West Virginia University

in partial fulfillment of the requirements for the degree of

Master of Science in

Geology

\title{
Richard Smosna, Ph.D., Chair
}

Kathy Bruner, Ph.D.

Tim Carr, Ph.D.

Department of Geology and Geography

Morgantown, West Virginia

2013

Keywords: Marcellus, Petroleum, Sequence Stratigraphy

Copyright 2014 Jared VanMeter 


\section{ABSTRACT \\ Regional Mapping and Reservoir Analysis of the Middle Devonian Marcellus Shale in the Appalachian Basin}

\section{Jared VanMeter}

The main purpose of this investigation is to define the distribution of organic-rich facies of the Middle Devonian Marcellus Shale in New York, Ohio, Pennsylvania, and West Virginia. The analysis is based on well-log data, primarily gamma-ray (the most common and best calibrated) and bulk-density logs (where available). Detailed log analysis has been performed to normalize the logs and define key indicators of reservoir quality. Stratigraphic correlations have been conducted to trace key formation across the study area.

The following maps were generated over the study area.

- Isopach maps of the Mahantango Shale, Marcellus Shale, Oatka Creek Member, Cherry Valley and Union Springs Member. These maps show the stratigraphic thicknesses of the various formations and members.

- Net thickness maps of the Marcellus Shale where the gamma-ray < 100 API and gamma-ray is between 100-180 API. The gamma-ray < 100 API map shows the thickness of the various limestone intervals within the Marcellus. The paleography of these intervals represents carbonate shoals along the basin margin (north and west) and over the peripheral bulge. The gamma-ray map between 100-180 API shows the net thickness of calcareous shale and gray shale. These intervals represent the shallow muddy sea above the thermocline.

- Net thickness maps of the Marcellus Shale where the gamma-ray >180 API, > 200 API, > 250 API, and > 300 API. These maps show the thickness and distribution of shale with different organic-richness within the Marcellus. The paleography of these shale intervals was the deep basin below the thermocline. These maps show the location of the better reservoir.

- Average gamma-ray over the Marcellus interval. This map shows the average gamma-ray value for the Marcellus Shale across the basin. The map can be used as an indication of the highest average organic-richness of the Marcellus Shale, and is best used in conjunction with the net thickness maps by comparing the thickest portion of the various maps and where they may overlap regionally.

- Net thickness maps of the Marcellus Shale where the bulk-density $<2.55 \mathrm{~g} / \mathrm{cc},<2.4 \mathrm{~g} / \mathrm{cc}$, and $<2.35 \mathrm{~g} / \mathrm{cc}$. These maps show various reservoir quality grades of organic-richness (where lower density equals higher quality).

- Isopach Maps of stratigraphic sequences and their systems tracts in the Marcellus Shale. Thin Transgressive Systems Tracts equal a condensed section, whereas thick Regressive Systems Tracts equal a major clastic influx.

These observations and others portrayed on this new series of maps provide a better understanding of the exploratory development of the Marcellus Shale in the Appalachian Basin. By using all of these maps in conjunction, the best target areas for oil and gas exploration can be identified and exploited. The sequence stratigraphic maps can be used for regional correlations and to develop target zones within the Marcellus Shale. 


\section{ACKNOWLEDGMENTS}

I would like to express appreciation and thanks to my advisor Dr. Richard Smosna, you have been a tremendous mentor for me and an inspiration in my work. I would like to thank you for encouraging my research and for allowing me to grow as a Geologist. Your advice on my research as well as on my career has been priceless. I would also like to thank my committee members, Dr. Kathy Bruner, and Dr. Tim Carr. Thank you both for listening to my defense, and for your brilliant comments and suggestions on my thesis. I would especially like to thank all the faculty and staff of the Geology Department at WVU. You all have helped mold me into the professional that I am today.

I would like to give a special thank you to the National Energy Technology Laboratories in Morgantown WV for funding my research and providing the data therein. I am very thankful that they allowed me to put this research into thesis format.

I would also like to thank all of my friends who supported me in writing, and encouraged me to strive towards finishing.

A special thanks to my family. Words cannot express how grateful I am to my mother-in law, Johnnie and my late father-in-law Fred. Fred, you may not be able to see me graduate like you wanted, but you will always be there in spirit. I would like to thank my mother and father, Kristi and Guy for all of the sacrifices that you've made on my behalf. You both were my guiding light and I couldn't have done it without you. At the end I would like express appreciation to my beloved wife Katie VanMeter who was there from beginning to end through the thick and thin. Who spent her evenings helping me search for data and digitizing logs on my behalf. There is no level of thanks that could express all of my gratitude for this! 


\section{TABLE OF CONTENTS}

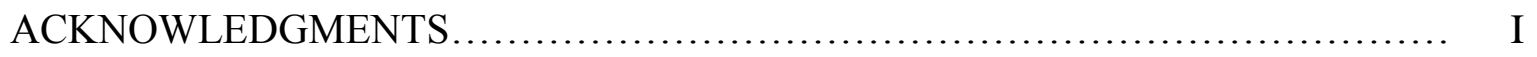

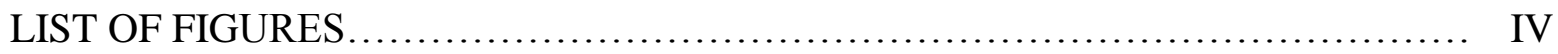

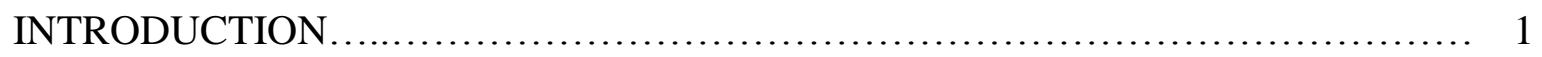

MIDDLE DEVONIAN STRATIGRAPHY OF THE APPALACHIAN BASIN ........ 3

DEPOSITIONAL SETTING OF THE MARCELLUS AND MAHANTANGO

FROMATIONS ............................................................. 15

AREA OF INVESTIGATION............................................... 21

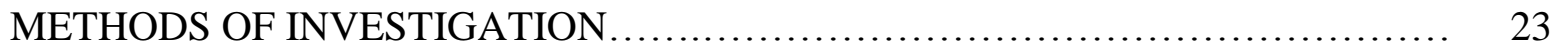

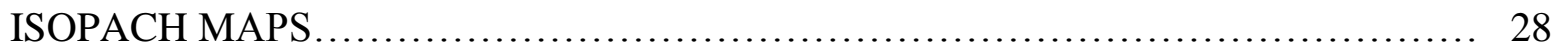

MARCELLUS SHALE ISOPACH.............................................. 28

UNION SPRINGS MEMBER ISOPACH............................... 33

CHERRY VALLEY MEMBER ISOPACH................................ 35

OATKA CREEK MEMBER ISOPACH................................... 37

MAHANTANGO FORMATION ISOPACH................................ 39

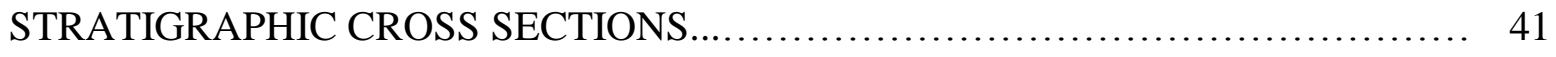

A-A' CROSS SECTION.............................................. 43

B-B' CROSS SECTION .................................................... 45

C-C' CROSS SECTION .............................................. 47

D-D' CROSS SECTION............................................... 49

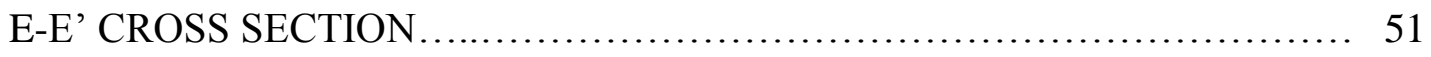

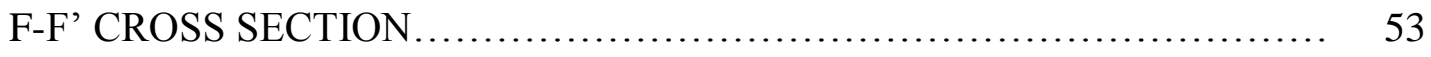

G-G' CROSS SECTION............................................... 55 
H-H' CROSS SECTION............................................... 57

I-I' CROSS SECTION............................................... 59

J-J' CROSS SECTION ....................................................... 62

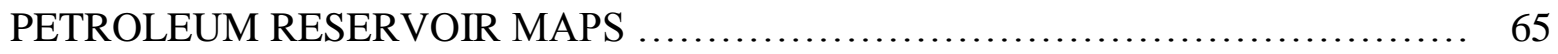

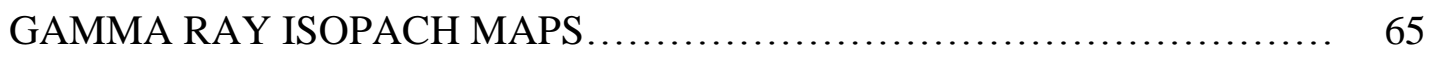

BULK-DENSITY ISOPACH MAPS ..................................... 79

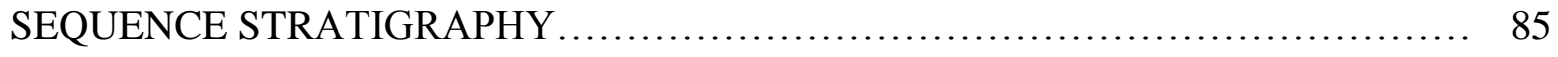

TRANSGRESSIVE REGRESSIVE SEQUENCE $1 \ldots \ldots \ldots \ldots \ldots \ldots \ldots \ldots \ldots . \ldots \ldots$

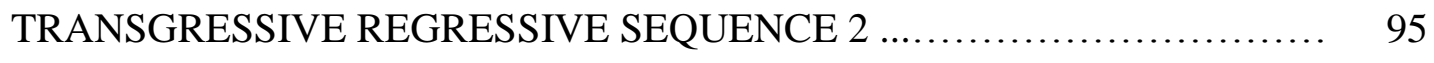

TRANSGRESSIVE REGRESSIVE SEQUENCE 3........................ 101

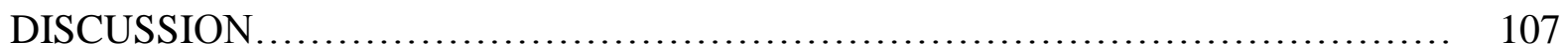

SEDIMENTOLOGY, STRATIGRAPHY, AND DEPOSITIONAL SETTING.. 107

PETROLEUM ISOPACH MAPS....................................... 112

COMPARISON OF GAMMA-RAY NAD BULK-DENSITY ISOPACH MAPS 118

SEQUENCE STRATIGRAPHY ........................................ 121

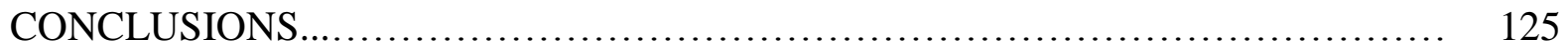

REFERENCES.......................................................... 128 


\section{LIST OF FIGURES}

Figure 1. Isopach map of the Hamilton Group ....................................... 6

Figure 2A. Hamilton Group Stratigraphy for New York and northern Pennsylvania...... 9

Figure 2B. Hamilton Group Stratigraphy for southern Pennsylvania and West Virginia... 9

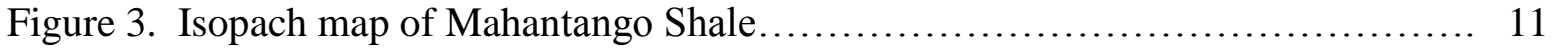

Figure 4. Isopach map of Tully Limestone......................................... 14

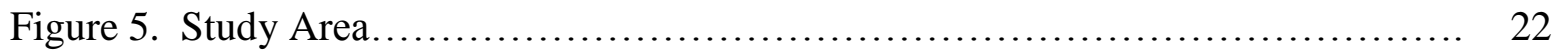

Figure 6. Location of data control points....................................... 24

Figure 7. Index line map for cross sections with total well spots.................... 26

Figure 8. Isopach map of Marcellus Shale ....................................... 29

Figure 9. Growth fault Rom Trough map......................................... 30

Figure 10. Map of major basement faults and lineaments............................. 32

Figure 11. Isopach map of the Union Springs Member of the Marcellus Shale............. 34

Figure 12. Isopach map of the Cherry Valley Member of the Marcellus Shale......... 36

Figure 13. Isopach map of the Oatka Creek Member of the Marcellus Shale................38

Figure 14. Isopach map of the Mahantango Shale ...................................... 40

Figure 15. Regional map showing the locations of all cross sections................... 42

Figure 16. A-A' Cross section...................................................... 44

Figure 17. B-B' Cross section........................................................... 46

Figure 18. C-C' Cross section...................................................... 48

Figure 19. D-D' Cross section.................................................. 50

Figure 20. E-E' Cross section...................................................... 52

Figure 21. F-F' Cross section...................................................... 54

Figure 22. G-G' Cross section.................................................. 56

Figure 23. H-H' Cross section....................................................... 58 


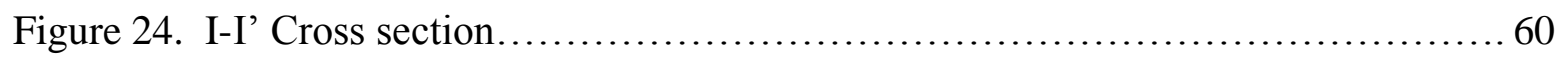

Figure 25. J-J' Cross section...................................................6 63

Figure 26. Marcellus net thickness less than 100 API................................. 66

Figure 27. Marcellus net thickness between 100 and 180 API......................... 68

Figure 28. Marcellus net thickness greater than 180 API............................. 70

Figure 29. Marcellus net thickness greater than 200 API.............................. 72

Figure 30. Marcellus net thickness greater than 250 API............................ 74

Figure 31. Marcellus net thickness greater than 300 API........................... 76

Figure 32. Marcellus average gamma-ray API Map................................. 78

Figure 33. Marcellus bulk-density net thickness map of feet less than $2.55 \mathrm{~g} / \mathrm{cc} \ldots \ldots \ldots \ldots . .80$

Figure 34. Marcellus bulk-density net thickness map of feet less than $2.4 \mathrm{~g} / \mathrm{cc} \ldots \ldots \ldots . . .82$

Figure 35. Marcellus bulk-density net thickness map of feet less than $2.35 \mathrm{~g} / \mathrm{cc} \ldots \ldots \ldots \ldots .84$

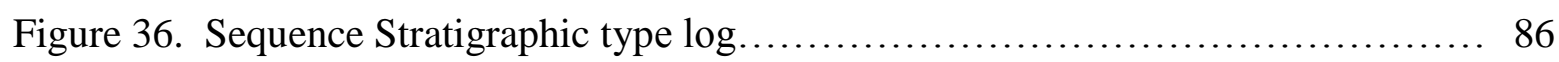

Figure 37. Location of sequence stratigraphic cross section.......................... 87

Figure 38. B-B' sequence stratigraphic cross section ............................ 88

Figure 39. Isopach map of the first Transgressive Regressive Sequence.................. 90

Figure 40. Isopach map of the first Transgressive Systems Tract........................ 92

Figure 41. Isopach map of the first Regressive Systems Tract........................ 94

Figure 42. Isopach map of the second Transgressive Regressive Sequence............. 96

Figure 43. Isopach map of the second Transgressive Systems Tract.................. 98

Figure 44. Isopach map of the second Regressive Systems Tract...................... 100

Figure 45. Isopach map of the third Transgressive Regressive Sequence.................. 102

Figure 46. Isopach of the third Transgressive Systems Tract........................ 104

Figure 47. Isopach map of the third Regressive Systems Tract...................... 106

Figure 48. Paleogeographic Map...................................................... 109 
Figure 49. Cross plot of RhoB vs TOC (From Laughrey 2009) .................. 116

Figure 50. Cross Plot of RhoB vs TOC\% (From Cluff 2009)................... 117

Figure 51. Cross Plot of $2.5 \mathrm{~g} / \mathrm{cc}$ RhoB vs gamma-ray greater than 180 API........... 120 


\section{INTRODUCTION}

The Devonian Marcellus Shale of the Appalachian Basin has been producing gas since the late 1800s, but only recently has it become a giant play. In 2005, Range Resources, using new drilling and fracturing techniques, began producing gas from a Marcellus Shale well in Washington County, Pennsylvania (Perry and Wickstrom 2010). Now the Marcellus Shale is the largest producer of unconventional shale gas in the United States. During the Eastern Gas Shale Project in the 1970s, it was estimated that the Marcellus contains 295 trillion cubic feet of gas in place throughout the basin (Harper 2008). Today it is estimated the Marcellus contains 500 trillion cubic feet of gas in place, with 50 trillion cubic feet of recoverable gas (Harper 2008).

Geologists in both academia and industry have mapped the Marcellus Shale extensively. However, there are many different methods and criteria for mapping, so that each study shows something different. Most authors identify the Marcellus Shale in the subsurface based upon a minimum gamma-ray value of 200 API units, which can typically be correlated to a TOC content of 5\% or more (Myers 2008, Lash and Engelder 2009, Boyce 2010, Zagorski and Wrightstone 2012). Other authors, however, identify the shale by a gamma-ray value as low as 175-180 API units (Piotroski and Harper 1979, Hill et al. no date). Still other authors identify the shale by a minimum gamma-ray value of 230 API units or higher (Cliff Minerals Inc. 1979, Hill et al. 2002, Zaengle 2008, Avery and Lewis no date). The purpose of this thesis research is to better understand the distribution of the organic-rich facies in the Marcellus Shale plus the overlying Mahantango Formation by using common well logging techniques and to clearly define the criteria for mapping these rocks. 
A second aspect of this present study is to correlate typical bulk-density values to the organic-richness of shale. Cliff Minerals Inc. (1979) showed that black shale can have bulkdensity values as low as $2.20-2.30 \mathrm{gm} / \mathrm{cc}$. This low density correlates to a TOC of $10 \%-12 \%$ (Gottschling 2007, Engelder 2008) and up to 20\% (Smith and Leone 2009). Low bulk-density reading is thought to represent the best, most organic-rich portion of the shale. Boyce (2010) used a much higher density cut-off value of $2.55 \mathrm{gm} / \mathrm{cc}$ to represent organic shale which correlates to $\sim 6-7 \%$ TOC.

Another aspect of this thesis is to identify, correlate, and map stratigraphic sequences across the Appalachian Basin. Previous sequence stratigraphic studies of the Marcellus Shale have identified small-scale stratigraphic changes that may help in predicting reservoir plays in areas with a low data spread. Mapping such sequence stratigraphic features may also help in selecting local target zones for directional drilling within the formation. The prominent gammaray signatures of these features can provide predictability in steering the drill bit in a lateral wellbore. Lash (2010) used the transgressive-regressive (T-R) sequence model in order to divide the Marcellus Shale into easily definable sequences defined by the rise and subsequent fall of relative sea level (Catuneanu 2006). These systems tracts of transgression and regression can be easily mapped from outcrop studies and gamma-ray logs. The maximum flooding surface is represented by the highest peak of the gamma-ray log in formation. The maximum regression is marked by the lowest trough of the gamma-ray log in the formation (Embry 2002, Catuneanu 2006, Lash 2010, Lash and Blood 2011). Mapping these key sequence stratigraphic surfaces should bring about a general understanding of the sequence of sedimentary events in the formation of the Marcellus Shale. 


\section{MIDDLE DEVONIAN STRATIGRAPHY OF THE APPALACHIAN BASIN}

The Middle Devonian Marcellus Shale is located in the northern part of the Appalachian Basin, primarily within the Allegheny Plateau province. The formation lies within the following states: southern New York, much of Pennsylvania, eastern Ohio, western Maryland, most of West Virginia, northern and western Virginia, and eastern Kentucky. The formation also extends across Lake Erie into southern Ontario. This area measures 50,000 square miles (Figure 3).

The Marcellus is the lower of two formations in the Hamilton Group. The Tully Limestone and above and the Onondaga Limestone, Huntersville Chert, or Needmore Shale below bound the group stratigraphically. Wherever these adjacent formations are present, the Hamilton Group can be delineated clearly in the subsurface (Reeves and Davies 1937, Dennison and Hasson 1976, Milici and others 2006).

Rocks underlying the Hamilton Group belong to the Onesquethaw Group (Schwietering 1981, Wrightstone 2008). The Onondaga Limestone ranges in thickness from 200 feet in western New York to less than 50 feet in central Pennsylvania (Figure 9.) (Reeves and Davies 1937, Van Tyne 1996). The formation consists primarily of calcarenitic to cherty to argillaceous limestones and minor shale (Brett and Ver Straeten 1994). The depositional environment was a shallow carbonate shelf in the western and northern portions of the basin. East of the Onondaga Limestone in West Virginia and Pennsylvania lies the age-equivalent Huntersville Chert. The chert trends through the center of the Appalachian Basin and ranges in thickness from 10-200 feet. The Huntersville Chert grades from impure chert in West Virginia 
into the cherty Onondaga Limestone in Pennsylvania and New York (Dennison 1961). There are seven main lithotypes within the Huntersville Chert: (1) clean chert, (2) chert with organic material, (3) spicular chert, (4) dolomitic chert, (5) glauconitic chert, (6) silty argillaceous chert, and (7) dolomitic silty argillaceous chert. However all of the chert contains some dolomite and quartz silt (Sherrard and Heald 1984). According to Cecil (2004), the source of the silica in the Huntersville Chert is due to biotic extraction of silica from seawater as well as aeolian sand and dust. East of the chert in West Virginia lies the Needmore Shale. The Needmore Shale is black or brown shale and interbedded limestone that was deposited in the deepest portion of the basin, the source of terrestrial sediments originating from the newly raised Acadian highlands to the east. The formation ranges in thickness from 100 feet in the far east to 10 feet near the basin center (Reeves and Davies 1937, Hasson and Dennison 1976, Van Tyne. 1996).

The zone of Tioga K-bentonite occurs near the base of the Marcellus, within the equivalent Millboro Shale in southern West Virginia, or in the underlying Needmore Shale or Huntersville Chert. The Tioga K-bentonite zone is composed of several individual ash deposits characterized by brown tuffaceous shale beds with biotite flakes and feldspar. The middle coarse zone consists of three thin tuffaceous beds that comprise a stratigraphic interval of less than 10 feet. The Tioga middle coarse zone marks the top of the Devonian Ornesquethaw stage. The origin of the ash bed was a volcano thought to be located in central Virginia around the area of Charlottesville. Due to the instantaneous nature of deposition, the Tioga is a stratigraphic time line dated at $390 \pm 0.5$ million years old (Dennison and Hasson 1961, Dennison and Textoris 1970, Hasson and Dennison 1987, Ver Straeten 2004). 
The Marcellus Shale and the Mahantango Formation combine to form the Hamilton Group (Figure 1). In New York, Pennsylvania, and West Virginia the boundary between the formations can be picked from well logs by a gamma-ray signature over 200 API. The Hamilton Group ranges from 250ft thick in western New York and Pennsylvania to 2,450 feet thick towards central New York and Pennsylvania (Reeves and Davies 1937). 


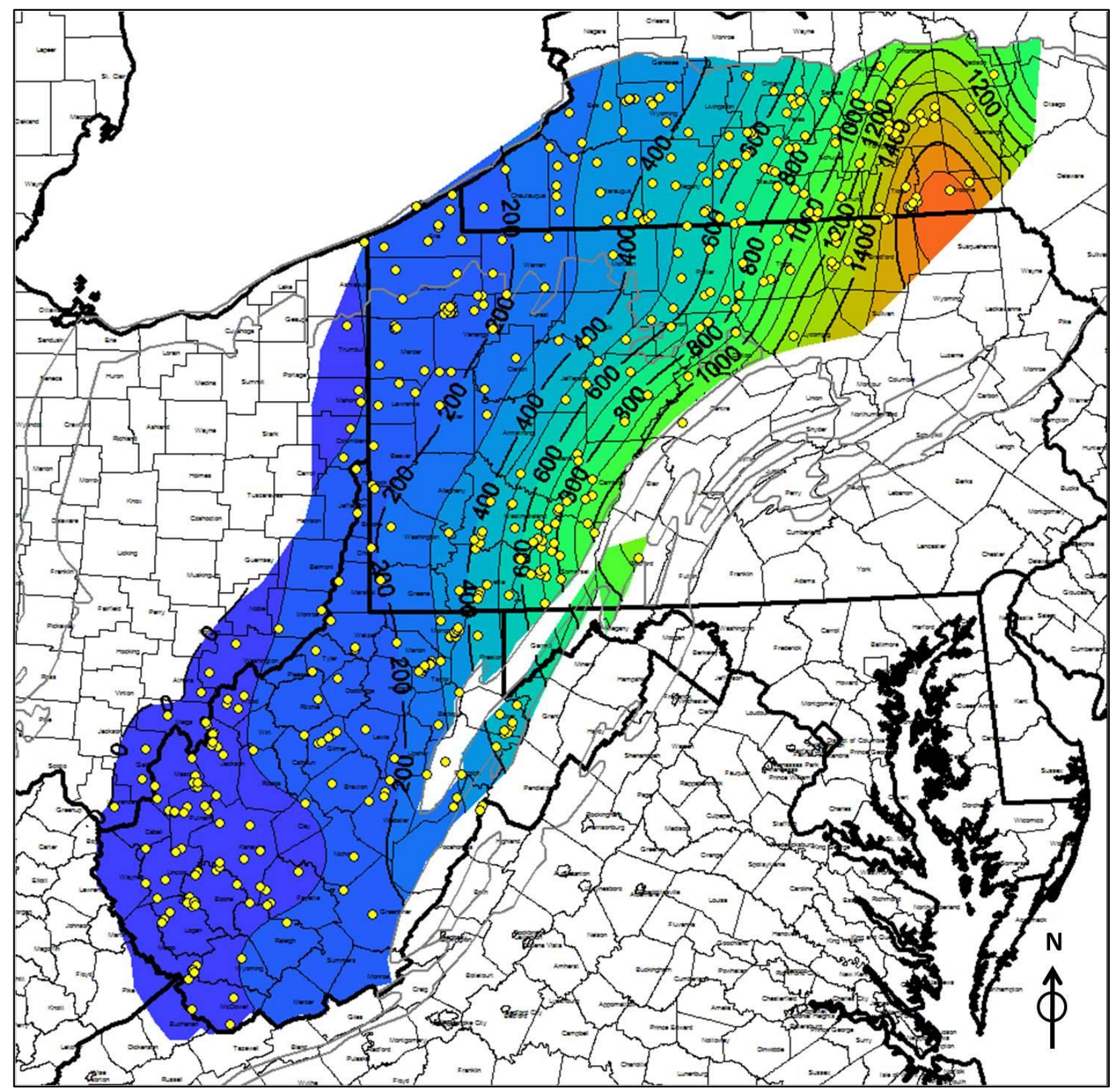

Figure 1. Isopach map of the Hamilton Group. Contour interval is 100 feet. 
The Marcellus Shale consists of radioactive, organic-rich black shale and gray shale with interbeds of calcareous shale and thin limestone (Schwietering 1981, Walker-Milani 2011). The shale contains finely macerated organic detritus which is generally responsible for the dark color of the rock (Roen 1984). The Marcellus is extremely fissile and exhibits "poker chip" fissility in outcrop (Avary 2009). The thinly laminated shale ranges in color from medium to light grey and black. The black shale occurs in two main variations: brownish black and olive black. The color is representative of high levels of iron, organic matter, and the calcite content within the shale (Dennison and Hasson 1976, Roen 1984).

In northern Pennsylvania and southwestern New York, the Marcellus Shale is divided into three members. The lowest is the organic-rich Union Springs Shale Member (Lash 2008, Wrightstone 2008). The Union Springs ranges in thickness from 200 feet in eastern Pennsylvania and New York to less than 10 feet in central Pennsylvania and western West Virginia (Figure 10). Erosion removed the Union Springs in a NE-SW trend in northwestern Pennsylvania and southwestern New York (Lash 2008). According to Lash (2008), the unconformity developed over a topographic high on the sea floor immediately after deposition of the Union Springs. This topographic high may have been a foreland bulge caused by the crust's isostatic response to orogenic loading in the eastern highlands. The middle member of the Marcellus is a calcareous shale and limestone member named the Cherry Valley in New York (Lash 2008, Wrightstone 2008). The Cherry Valley Member has an average thickness of 10 feet but can be as thick as 100 feet in southern Pennsylvania and eastern West Virginia. The Cherry 
Valley is generally thought to be stratigraphically equivalent to the Purcell Member in West Virginia (Dennison and Hasson 1976, Neal 1979). Finally, the Oatka Creek Shale Member of the Marcellus Shale is organic-rich at the base and grades upward into undifferentiated gray shale. The Oatka Creek ranges in thickness from 10 feet in western Pennsylvania and southern West Virginia to over 100 feet thick in eastern Pennsylvania and New York (Figure 2A-B) (Dennison and Hasson 1976, Schwietering 1981, Milici et al. 2006, Lash 2007). 


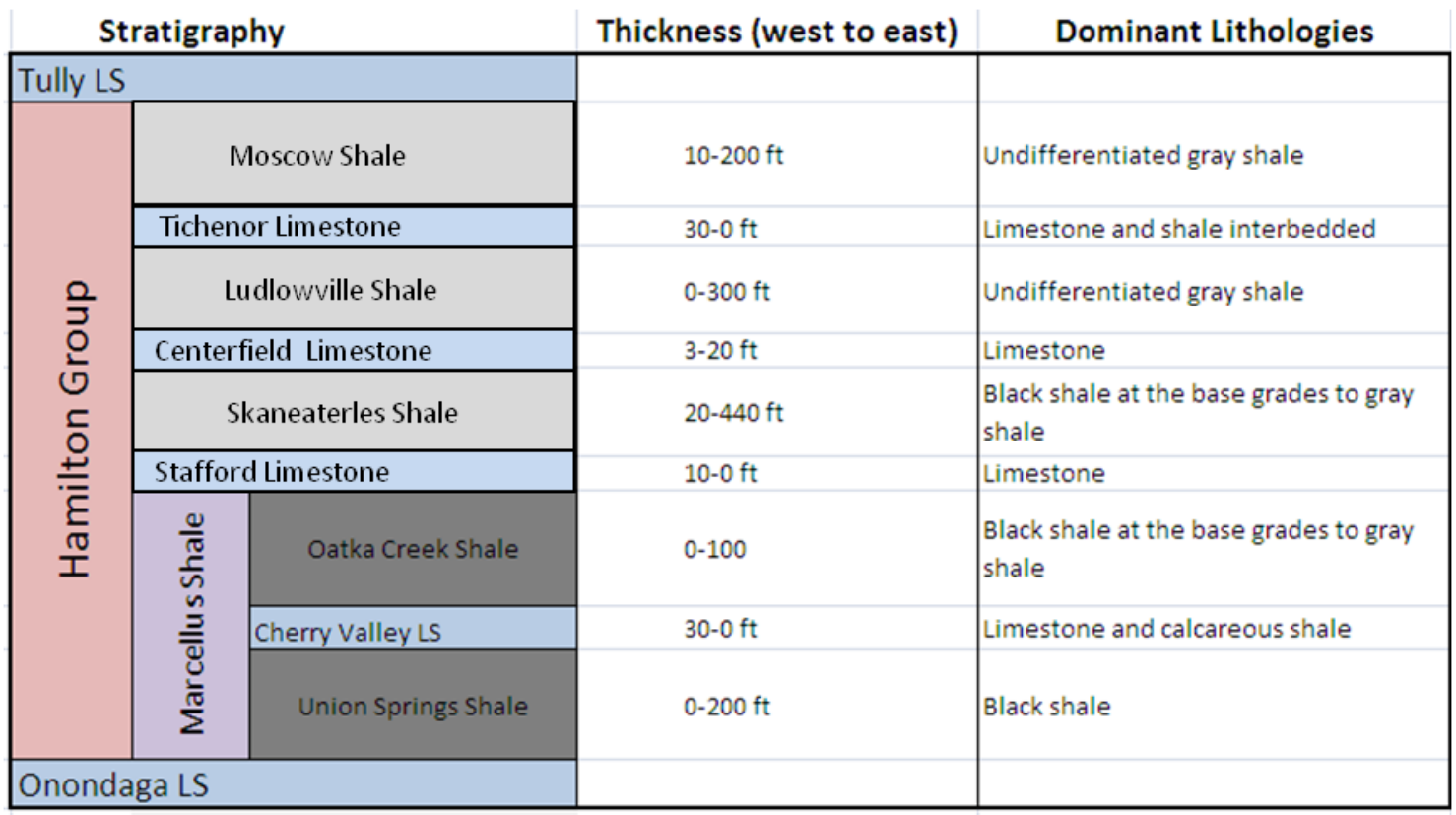

(Roen 1984, Hasson and Dennison 1987, Lash 2007, Wrightstone 2008).

Figure 2A. Hamilton Group stratigraphy for New York and northern Pennsylvania.

\begin{tabular}{|c|c|c|c|c|}
\hline \multicolumn{3}{|c|}{ Stratigraphy } & Thickness (west to east) & Dominant Lithologies \\
\hline \multicolumn{5}{|c|}{ Tully Limestone } \\
\hline \multirow{7}{*}{ 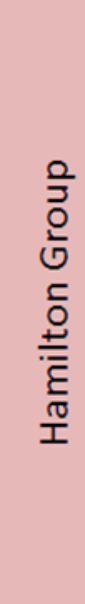 } & \multirow{4}{*}{ 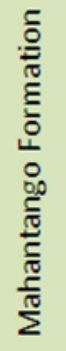 } & Clearville Siltstone & $60-200 \mathrm{ft}$ & Siltstone \\
\hline & & Frame Shale Member & $0-100 \mathrm{ft}$ & $\begin{array}{l}\text { Gray to olive sandy shale with } \\
\text { sandstone and limestone lenses }\end{array}$ \\
\hline & & Chaneysville Member & $0-50 \mathrm{Ft}$ & Olive-gray, brown massive Siltstone \\
\hline & & Eander Run Shale Membe & $200-850 \mathrm{ft}$ & Undifferentiated gray shale \\
\hline & \multirow{3}{*}{ 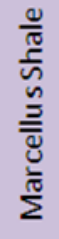 } & Oatka Creek Member & $0-100$ & $\begin{array}{l}\text { Black shale at the base grades to gray } \\
\text { shale }\end{array}$ \\
\hline & & Purcell Limestone & $0-100$ & Limestone and calcareous shale \\
\hline & & Union Springs Member & $0-200 \mathrm{ft}$ & Black shale \\
\hline \multicolumn{3}{|c|}{ Tioga K-Bentonite } & $0-10$ & K-Bentonite \\
\hline \multicolumn{3}{|c|}{ Onondaga/Huntersville/Needmore } & & \\
\hline
\end{tabular}

Figure 2B. Hamilton Group stratigraphy for southern Pennsylvania and West Virginia. 
To the west, in Ohio the Marcellus is equivalent to the Delaware Limestone. In northern Virginia and southern West Virginia, the Marcellus Formation becomes equivalent to the lower Millboro Shale (Milici et al. 2006). In this region, the Mahantango Formation and Tully Limestone pinch out so that the Upper Devonian Harrell Shale rest directly upon the Marcellus. This combined interval --Marcellus Shale through Harrell Shale-- is termed the Millboro Shale (Dennison and Hasson 1976).

The thickness of the Mahantango formation ranges from 1,600 feet in eastern Pennsylvania, western Maryland, and southeastern New York, and pinches out in western Pennsylvania and southern West Virginia (Figure 3) (Dennison and Hasson 1976, Hasson and Dennison 1987, Milici et al. 2006, Harper 2008, Boyce 2010). In western New York and Pennsylvania, the Mahantango is divided into several formations such as the Skaneateles, Ludlowville, and Moscow Shale. Directly above the Marcellus in northwestern Pennsylvania and southwestern New York lies the Stafford Limestone Formation (Fig 2A). 


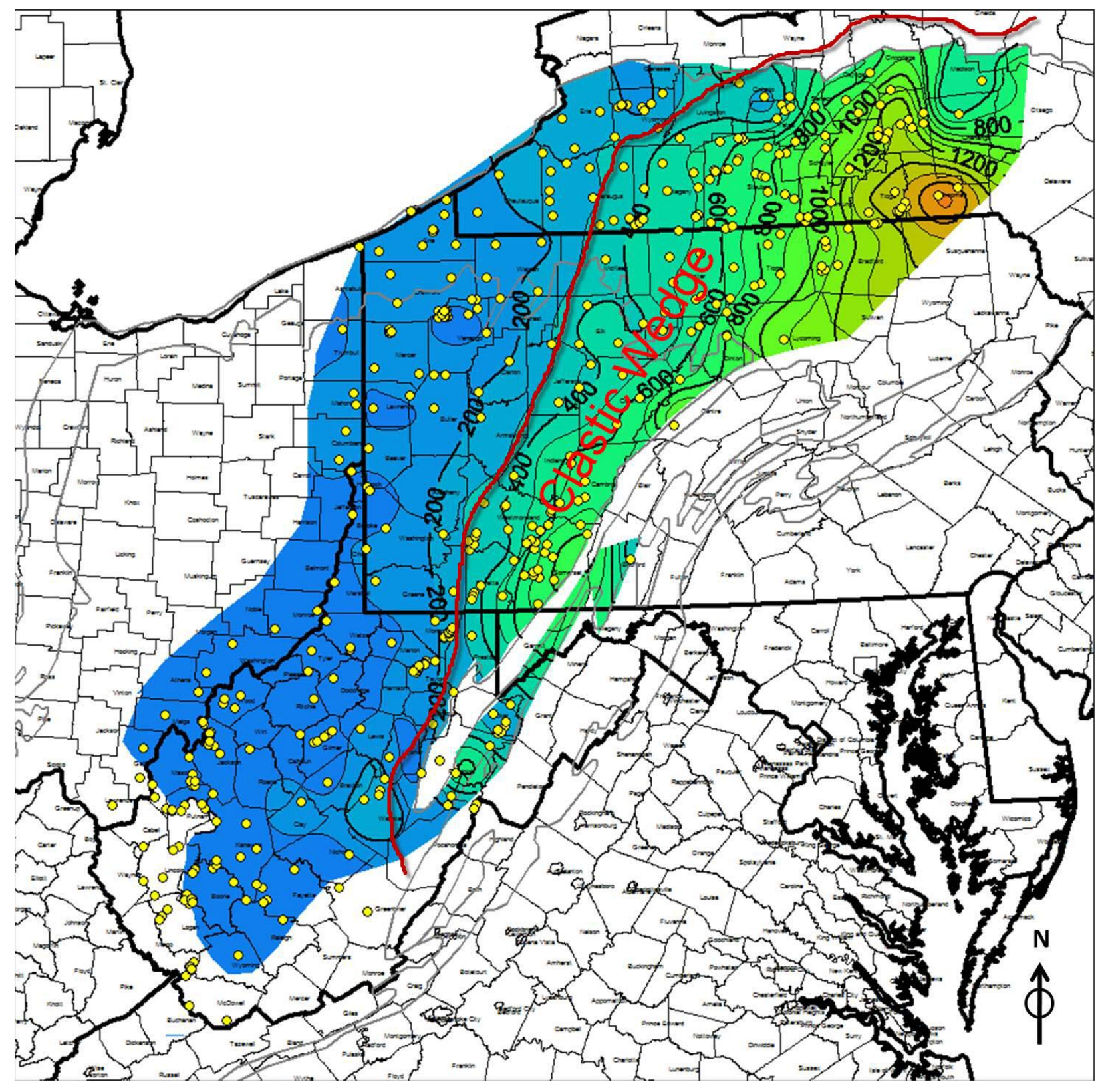

Figure 3. Isopach map of the Mahantango Shale. The red solid line represents the main body of the clastic wedge. Contour interval is 100 feet. 
In West Virginia, the Mahantango Formation is divided into three major members that are predominantly siltstone with some limestone and sandstone interbeds. These change facies into undifferentiated grey shale in north-central West Virginia. The members from bottom to top are the Gander Run Shale, the Chaneysville Siltstone, the Frame Shale, and the Clearville Siltstone (Hasson and Dennison 1987). (Fig 2B)

The Mahantango is dominated by thickly laminated, very silty shale and grey shale interbedded with siltstone, sandstone, and limestone beds. Lash (2007) recognized many small packages within the Mahantango equivalent of New York showing a coarsening upward trend of organic-rich shale at the base, passing upward into undifferentiated gray shale and finally into siltstone with a cap of limestone or sandstone. There are three major depositional systems within these Mahantango rocks: storm dominated offshore marine mudstone and fine sandstone, storm dominated nearshore marine shelf and shoreface sandstone, and tide-dominated shoreline deposits consisting of variably bedded sandstone, pebbly sandstone and mudstone (Prave et al. 1996). The cyclicity of the Mahantango formation depicts an episodic advance and retreat of a tide-dominated shoreline onto a storm-dominated shelf.

The formation overlying the Hamilton Group is the Tully Limestone. The Tully Limestone is absent in western Pennsylvania and New York and southern parts of West Virginia, which makes the proper identification of the upper Hamilton Group boundary extremely difficult. In southern West Virginia, the Tully becomes a part of the Millboro Shale or disappears altogether. The Tully Limestone is composed of dark-gray argillaceous limestone. As it passes eastward, it becomes a calcareous shale in south-central Pennsylvania, western Maryland, and the eastern panhandle of West Virginia. The limestone is thickest along the axis 
of anticlines such as the Chestnut Ridge anticline in the center of the basin at 90 feet thick, and decreases in thickness to the west, east, and south from the center portion of the basin. The increased thickness on anticlines could be the cumulative effect of many antithetic faults. The limestone was deposited in a shallow marine setting along the central portion of the Epicontinental Sea (Figure 4.) (Roen 1984, Schwietering 1981, Hasson and Dennison 1987). 


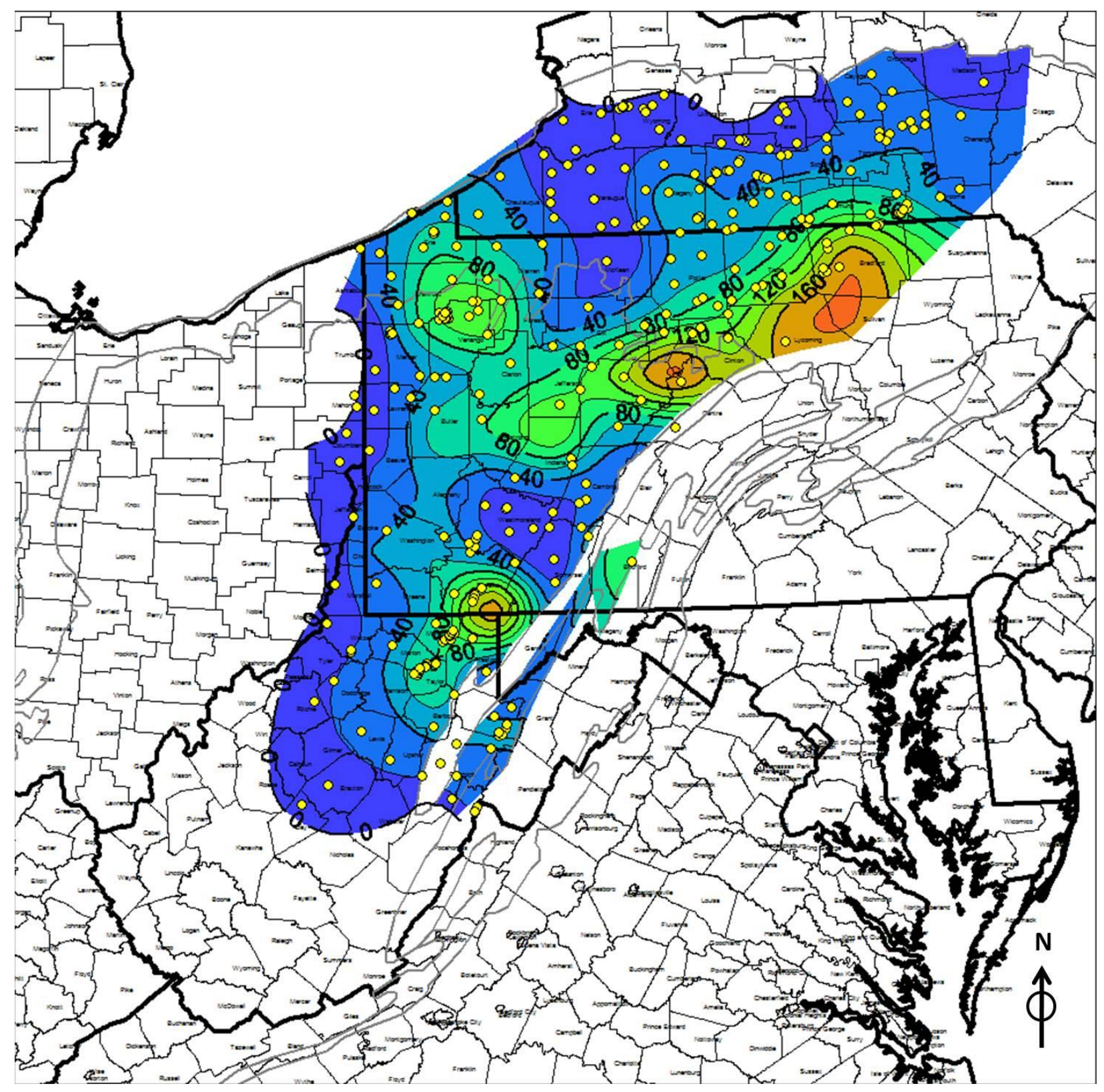

Figure 4. Isopach map of the Tully Limestone. Contour interval is 20 feet. 


\section{DEPOSITIONAL SETTING OF THE MARCELLUS AND MAHANTANGO}

The Devonian was a time of eustatic sea-level rise (Ettensohn 2008). During the Acadian orogeny, as the Acadian Mountains were uplifted possibly as much as $4 \mathrm{~km}$ (Wrightstone 2010), the black and gray shale and siltstone of the Hamilton Group began accumulating in the foreland basin. Erosion of the mountains supplied these terrigenous sediments through the Catskill delta complex on the eastern margin of the basin (Schwietering 1981). The Marcellus Shale formed to the west in a sediment-starved, anoxic trough that paralleled the mountain chain. Large dust storms may have deposited aeolian quartz silt in the Marcellus (Mazzullo 1972, Prave et al. 1996, Wrightstone 2010).

During Marcellus time, the Appalachian Basin was located somewhere between $15^{\circ}$ and $30^{\circ}$ South latitude; however the exact location is still heavily debated. The subtropical warmth and increased sunlight in this location enhanced the growth of marine phytoplankton (Wrightstone 2010). This plankton settled to the bottom and formed an organic-rich detritus, which was preserved in to the anaerobic environment (Boyce 2010).

The shallowest portion of the basin was along the eastern margin nearest the Acadian Mountains. As the basin filled, seven deltaic depositional environments are recognized in southeastern New York in the Mahantango Formation: 1) alluvial and delta-plain, 2) wave and tide-dominated beach facies, 3) channel-mouth bar facies, 4) outer delta-platform facies, 5) interdistributary bay facies, 6) delta-slope facies, and 7) the prodelta facies. Water depth may have ranged from extremely shallow (less than 100 feet) to very deep (greater than 300 feet). The vertical successions of these environments reflect the progradation of the delta complex over a shallow marine shelf during times of tectonic quiescence (Mazzullo 1972). 
Prave et al. (1996) offered another interpretation of the Mahantango. Depositional cyclicity may have resulted from repeated progradation and retreat of a straight, tide-influenced shoreline system onto a storm-dominated marine shelf. This interpretation is based on three depositional systems inferred from the Mahantango Formation. The three systems are as follows: 1) storm dominated offshore marine mudstone and fine sandstones, 2) storm dominated near shore marine shelf and shoreface sandstone, and 3) tide-dominated shoreline sandstone, pebbly sandstone and mudstone. They are systematically arranged in thickening- and coarsening-upward cycles capped by transgressively reworked lag deposits (Prave et al. 1996).

In western New York strata equivalent to the lowest Mahantango (Skaneateles Formation) include limestone, calcareous shale, gray shale, and organic-rich shale (Lash and Engelder 2011). The organic-rich shale has a well-log character similar to that of the Marcellus and, in fact, can be mistaken for the Marcellus (Lash and Engelder 2011). These shale and limestone were deposited in an offshore prodeltaic environment far removed from the eastern shoreline.

In Ettensohn's (2009) depositional model, clay-sized particles transported from the eastern Acadian Mountains remained suspended, finally coming to rest at the bottom of the Appalachian Basin, tens of miles from the shore, at depths up to 500-900 ft or more. At these depths the water would have been sufficiently anoxic to preserve any accumulation of organic matter. This coupled with the rain-shadow effect of the Acadian mountains would have led to sediment starvation and further preserved the organic matter (Alegeo and Schekler 1998, Walker-Milani 2011). 
An alternate model shows that the deepest portion of basin may have been as shallow as $300 \mathrm{ft}$. or less (Schwietering 1981, Prave et al 1996, Boyce 2010, Walker-Milani 2011). At depths this shallow, the warm water needed to be sufficiently stratified so that the oxygen-rich portion of the water column did not mix with the anoxic bottom (Boyce 2010). Uranium and thorium identified in spectral gamma-ray logs were incorporated into the sediments syndepositionally, rather than being introduced into the formation later (Ettensohn 2008, Bank 2009). Sediment starvation occurred on the shallow shelf of the western margin whereas the basin center to the east acted as a trap on the clastic sediment from the mountains (WalkerMilani 2011).

Another interpretation states that the preservation of the organic content was controlled by three main factors: 1) the photosynthesis of phytoplankton, 2) bacterial decomposition, and 3) bulk sedimentation rate (Wrightstone 2010). In this interpretation, organic-rich units were not deposited under deep, permanently anoxic-sulfidic water columns, but rather in an extremely shallow (less than 100 feet) stratified water column that may have changed seasonally. WalkerMilani (2011) attributed the deposition primarily to terrigenous sediment supply that was dependent upon sea level. Low sediment supply favored the preservation of organic sediment; whereas high supply diluted the organics. A thermocline was established and destroyed seasonally (Werne et al. 2002, Walker-Milani 2011). The influx of aeolian sediment from giant dust storms on the basin margins may have triggered widespread algal blooms that produced basin-wide anoxia. The sudden die-off of these algal blooms promoted bacterial processes that acted to keep the bottom water anoxic, long enough to accumulate organic carbon on the sea floor (Wrightstone 2010). This, combined with the seasonal stratification and mixing, would 
have promoted the recycling of biochemical nutrients and played a key role in the preservation and accumulation of the organic matter (Sageman et al. 2003).

The Marcellus organic-rich units were deposited and accumulated in an area of maximum organic production, maximum preservation, and minimum non-aeolian siliclastic sediment influx (Wrightstone 2010). Relative sea-level rise and fall directly influenced the accumulation of the organic matter. Sea level rise led to sediment starvation and increased organic carbon concentrations in the distal basin sediments (Murphy et al. 2000). Siliclastic-sediment starvation is associated with organic carbon enrichment, and the highest level of total organic carbon content is related to the greatest transgression of relative sea level. High concentrations of aeolian silt are also indicative of high amounts of organic matter. An increase in non-aeolian clastic sediment influx and water column mixing during relative sea-level fall acted to dilute the surface sediment and decrease the volume of organic matter in the sediment (Sageman et al. 2003).

Ettensohn (1985) and Lash (2007) concluded that the accumulation of the black shale represents an episode of rapid, tectonic subsidence below the pycnocline and was linked to great water depth instead of marine algae blooms. The Marcellus Shale is considered the basal formation of the second tecto-phase of the Acadian Orogeny. During this phase, the Avalonian plate docked onto the continental margin of Laurasia, and the basin began to subside at a rate faster than that of sedimentation (Ettensohn 1985, Lash 2007). As the initial pulse of plate docking slowed, basin subsidence began to decrease. 
Sedimentation rates eventually overcame the rate of subsidence and the coarse clastics of the overlying Mahantango Formation prograded over the distal mud. The first deposits of grey shale and siltstone above the Marcellus Shale mark this shallowing event.

Although tectonism acted as the main control on Marcellus and Mahantango sedimentation, other processes influenced local deposition. Biological processes produced the limestone, which may be found interbedded within the shale and siltstone. Repeated small-scale tectonic pulses, reflecting the minor movement of the thrust systems, may account for the close interbedding of black shale, siltstone, and limestone (Ettensohn 2005).

Once tectonism ceased, there was a period of quiescence and relative sea level lowstand. The warm, shallow, sediment-starved sea promoted the deposition of the Tully Limestone (Schwietering 1981, Ettensohn 1985).

As plate docking continued and the basin continued to subside, a foreland bulge began to uplift on the western side of the basin (Ettensohn 2005, Lash 2007, Lash and Engelder 2009). This NE-SW trending tectonic feature played a key role in the stratigraphic thickness of the Marcellus Shale in southwest New York and northwest Pennsylvania. The bulge formed a topographic high that led to local erosion of the Union Springs and, later, the Oatka Creek Member (Lash and Engelder 2009). In addition to the foreland bulge, basement structures such as the Rome Trough and various lineaments that strike across the basin may have influenced seafloor highs and lows. These highs and lows caused local variations in the thickness of the shale or created isolated sub-basins within the foreland basin (Lash 2007).

Lash and Engelder (2009) used a sequence-stratigraphic approach to model Marcellus sedimentation. In the underlying Onondaga Limestone lies a maximum regressive surface that 
serves as a lower sequence boundary. The Marcellus Shale was deposited under two sequences of sea level rise and fall. The first sequence of transgression and regression began during the final deposition of the Onondaga Limestone. Sea level rose, flooding the basin, and the Union Springs Member was deposited. The maximum surface of transgression is marked by a thin, pyritiferous condensed section near the base of the Union Springs. Above the Union Spring, the Cherry Valley Limestone member was deposited during a time of relative tectonic quiescence and marks the maximum regressive surface or second sequence boundary of deposition. In the next depositional sequence sea level began to rise once again and the Oatka Creek was deposited. The maximum transgressive surface is once again marked by a highly radioactive, condensed section near the base of the Oatka Creek. Sea level then began to regress, as can be seen in the wireline logs as a coarsening-upward succession of the Oatka Creek. The Stafford Limestone above the Marcellus was deposited during this regression and marks the next maximum regressive surface and the end of the second stratigraphic sequence (Lash 2007, Lash and Engelder 2009). 


\begin{abstract}
AREA OF INVESTIGATION
The focus area for this study (Figure 5) encompasses portions of four states: New York, Pennsylvania, Ohio, and West Virginia, all of which fall within the Appalachian Basin. The extent of the generated maps cover approximately 83,000 square miles (214,000 sq-km) (Wrightstone 2011). This area was chosen for two main reasons, (1) it contains a wealth of subsurface data in the form of gamma-ray and bulk-density logs and (2) it falls within the core area of Marcellus exploration and development.
\end{abstract}




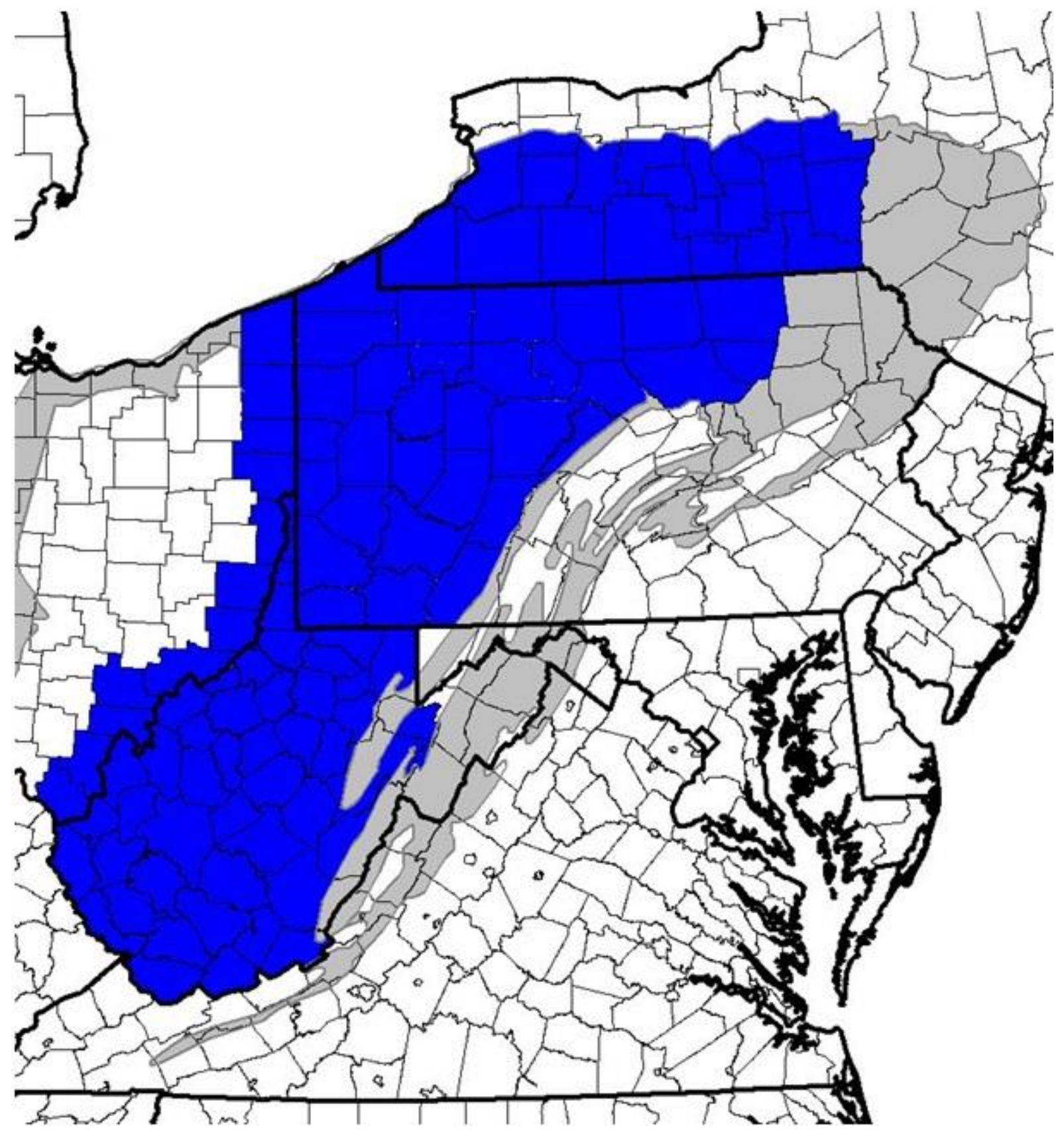

Figure 5. Study area showing the Marcellus Shale (blue) in New York, Pennsylvania, Ohio, and West Virginia with the Devonian outcrops (grey) to the east. 


\section{METHODS OF INVESTIGATION}

In this study, the Middle Devonian Marcellus Shale was analyzed to determine the extent of organic-rich rocks within the basin using criteria directly applicable to industry. The largest portion of available data came from geophysical logs utilizing gamma-ray and bulk-density curves. Gamma-ray and Density log data from 498 well logs in WV, OH, NY, and PA were utilized for this study. Where available, neutron and resistivity log data were also analyzed to better confirm the nature of each sedimentary package and to aid in correlation. Well logs from this study were primarily taken from proprietary data obtained from TGS-NOPEC Geophysical Company. Where there are gaps in well-log data obtained from TGS, additional wells were obtained from the Oil and Gas Division of the Pennsylvania Geologic Survey and the West Virginia Geologic and Economic Survey.

The first step, and the most important to this work, involved gathering and correlating the well $\log$ s throughout the study area. Figure 6 is a map of the well locations which were used for analysis. The Marcellus Shale and its members are the main stratigraphic units of interest and were correlated across the study area using the closed-loop method. The largest portion of the data was correlated using the gamma-ray logs. All of the log data was loaded into

GeoGraphix ${ }^{\mathrm{TM}}$ software, and correlations were made using the GeoAtlas module and XSection module of the program. Due to the variability of age among the well logs, an attempt was made to normalize curves which appeared to be too high or too low in API units from the standard type curves. 


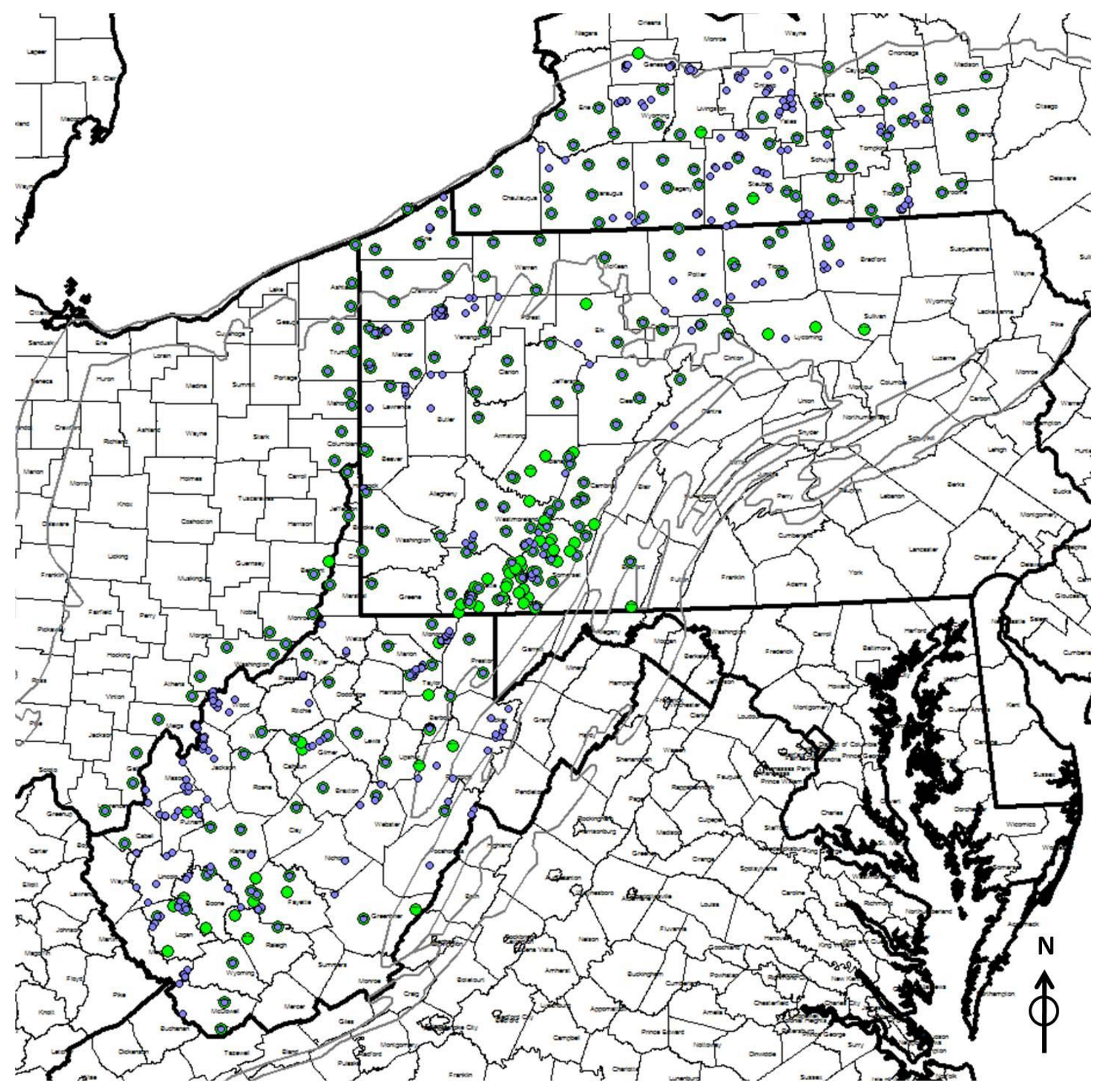

Figure 6. Location of data control points from digitized well logs (green) and rastor logs (purple) used in this study. 
Formation tops, formation bottoms, and net thickness were determined for each organicrich member. The author chose a cut-off value of greater than 160 API units between organicrich shale (>160 API) and undifferentiated gray shale (100-160 API). The author chose a cut-off value of 100 API units to represent "clean strata" such as limestone and some non-organic shale. Other API cut-offs were used to determine the varying amounts of radioactivity within the Marcellus, including 180 API, 200 API, 250 API, and 300 API units, to determine which criterion is most effective in the interpretation of total organic content in the Marcellus Shale. In addition bulk-density cut-offs were also used: less than $2.5 \mathrm{G} / \mathrm{cm}^{3}$, less than $2.4 \mathrm{G} / \mathrm{cm}^{3}$, and finally less than $2.35 \mathrm{G} / \mathrm{cm}^{3}$. Thickness data was used to generate cross plots of the gamma-ray API data vs the bulk-density data for a comparative analysis.

A series of isopach maps for each lithologic unit identified in the Marcellus shale were generated. Net thickness organic-rich shale maps were also created for the Marcellus. An isopach map of the gross thickness of the Mahantango Formation was also generated.

Ten cross-sections were generated, eight dip lines (SW-NE) and two strike lines (NESW) (Figure 7). The positioning of each cross section was controlled by the geometry of the isopach maps. This was done in order to generate sections both on-trend and off-trend, especially in the Marcellus Shale. 


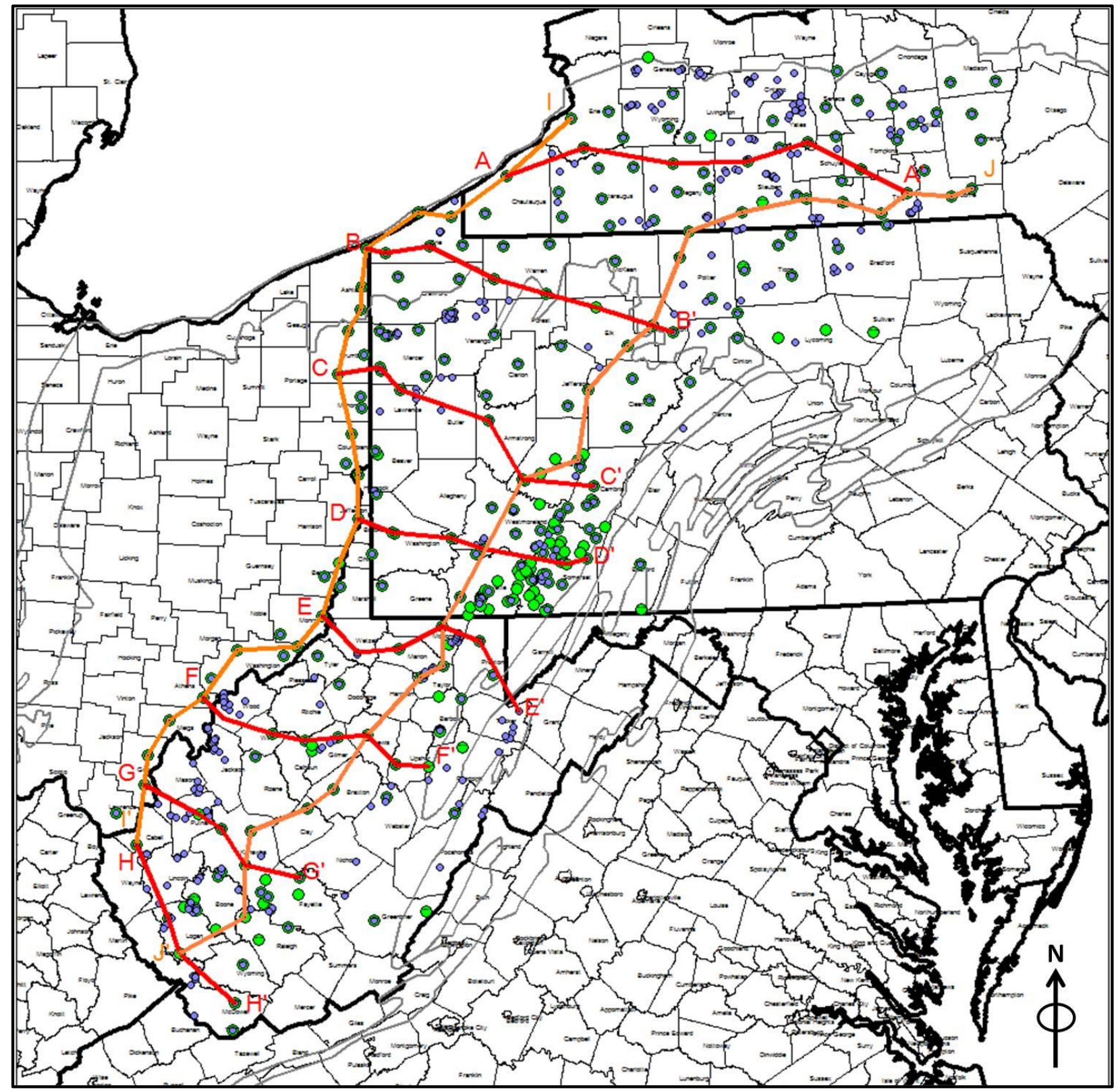

Figure 7. Index line map for the ten cross sections generated in this study with total well spots overlaid. See appendix for further information on each well used in the cross sections. 
The datum used to correlate the section is the top of the Onondaga Limestone. This datum is easily correlated and regionally widespread throughout the study area, except in the far west and eastern extents of the study area were the Onondaga Limestone pinches out.

A sequence stratigraphic analysis using the transgressive - regressive model (Catuneanu 2006, Embry 2009) of sedimentation was applied to the Marcellus in this study. Peaks in the gamma-ray represent maximum flooding surfaces whereas troughs represent maximum regressive surfaces. A sequence begins at the first maximum regressive surface and extends upward past the maximum flooding surface to the next maximum regressive surface higher in the section. Each surface was correlated across the study area, and isopach maps showing the thickness of each sequence and systems tract were generated. Systems tracts are taken to represent a single time slice of the local stratigraphy (Catuneanu 2006). 


\section{ISOPACH MAPS}

\section{MARCELLUS SHALE ISOPACH MAP}

Figure 8 is the isopach map for the Marcellus Shale within the study area, and a number of features are apparent from its distribution. The body of the formation strikes $\mathrm{N} 45^{\circ} \mathrm{E}$ with the depocenter [axis of greatest thickness approximately 220 feet $(67 \mathrm{~m})$ thick], occurring near the

study's eastern edge. From this thick, the shale thins to the west to a feather edge (10 feet or 3 m) in northwestern Pennsylvania and southwestern New York. Likewise, in West Virginia the thickest portion of the shale is approximately $150 \mathrm{feet}(45.7 \mathrm{~m})$ to the east, and thins to less than 20 feet in western West Virginia and southeastern Ohio. The strike of the Marcellus Shale depocenter seems to be shifted slightly eastward from the main strike of the Rome Trough, which is thought to have exerted a direct influence on basin deposition (Ettensohn 2005 (figure 9)). 


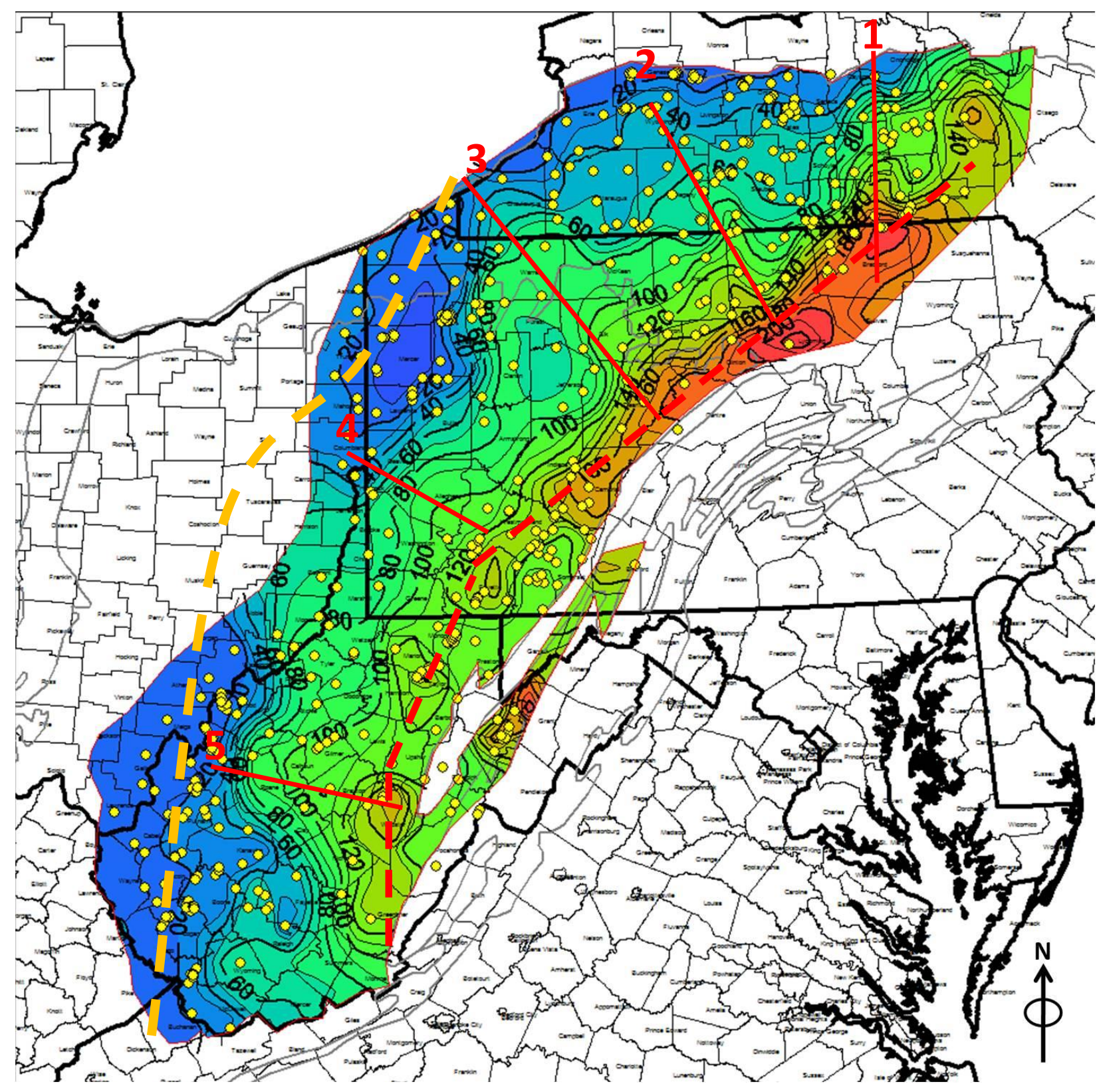

\begin{tabular}{|l|l|l|l|l|llllllll}
0 & 20 & 40 & 60 & 80 & 100 & 120 & 140 & 160 & 180 & 200 & 220 \\
\hline & & & & & & & & & & & &
\end{tabular}

Figure 8. Isopach of the Marcellus Shale where the red-dashed line represents the main body of deposition, the red solid lines represent cross strike thickness features, and the yellow-dashed line represents the trend of the thinning. Contour interval is 10 feet. 


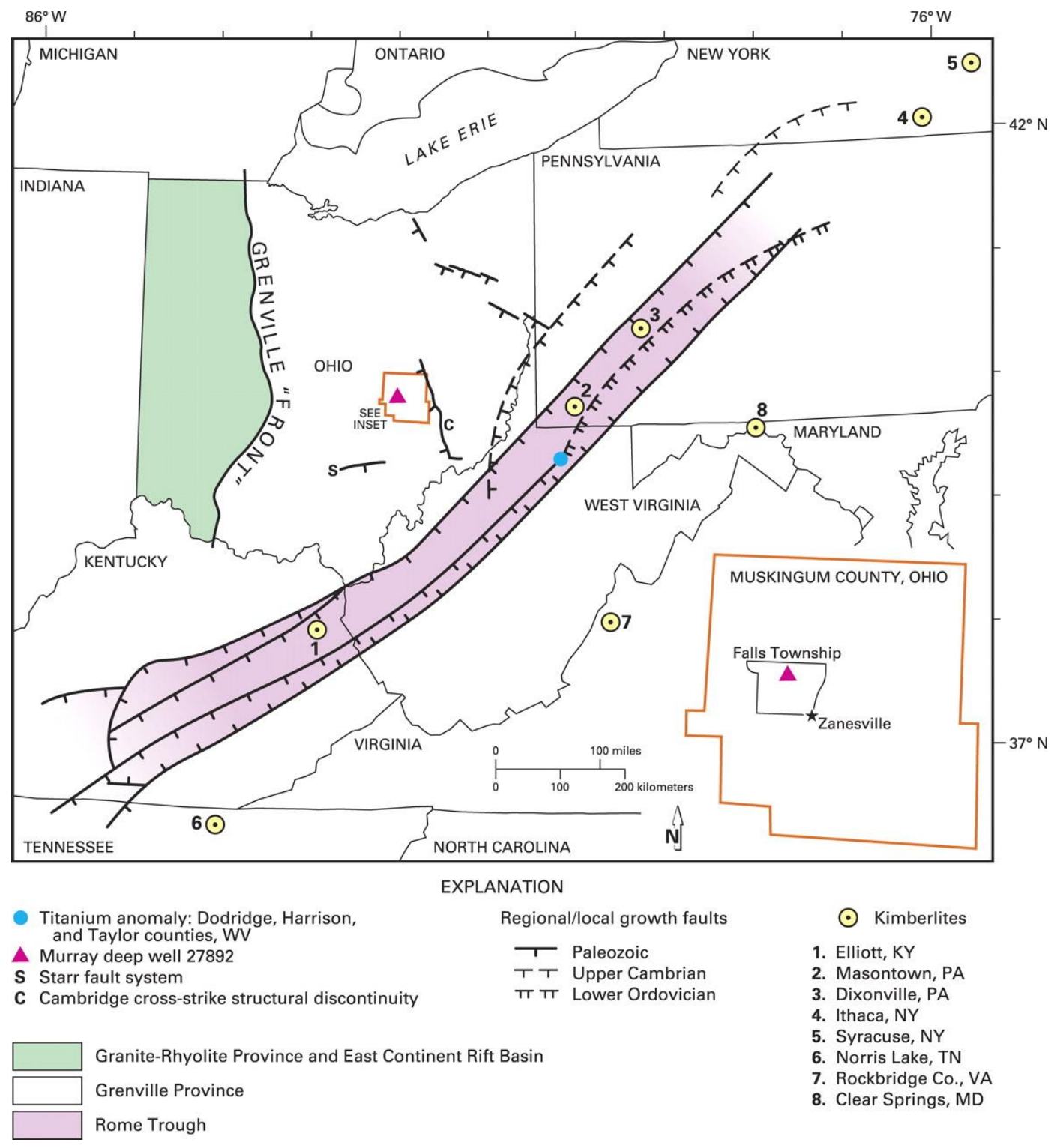

Figure 9. Map depicting the growth faults of the Rome Trough (From Ettensohn 2006). 
Within the Marcellus Shale there appear to be 5 cross-strike thickening trends that are lobe-shaped (represented by solid red lines on Figure 8). The first occurs in northeastern Pennsylvania and strikes due north into southern New York. The thickest portion of this crossstrike feature is approximately 190 feet $(58 \mathrm{~m})$ in Bradford County PA, to 120 feet $(36.6 \mathrm{~m})$ in Tioga and Broome Counties, NY. The second cross-strike thickness trend is located in northeastern Pennsylvania and strikes northwest into southwestern New York. The thickest portion of this cross-strike feature is approximately 200 feet $(87.8 \mathrm{~m})$ in Lycoming County, PA, and thins to less than 60 feet $(18.3 \mathrm{~m})$ in Allegany and Steuben County NY. The third occurs in central Pennsylvania and strikes northwest into southwestern New York. The thickest portion of this cross-strike feature is approximately 180 feet $(54.9 \mathrm{~m})$ in Centre County, PA, to less than 40 feet (12.2 m) in Chautauqua County, NY. The fourth occurs in southwestern Pennsylvania and strikes northwest into eastern Ohio. The thickest portion of this cross-strike feature is approximately 140 feet $(42.7 \mathrm{~m})$ in Fayette County, PA, to less than 60 feet (12.2 m) in Jefferson County OH. The fifth occurs in central West Virginia and strikes west-northwest into southeastern Ohio. The thickest portion of this cross-strike feature is approximately 150 feet (45.7 m) in Webster County, WV, to less than 20 feet $(6 \mathrm{~m})$ in Meigs County, OH. These thickness trends coincide with lineaments (Fig. 10) that cross the strike of the basin and show a left lateral fault movement (Zagorski and Emery 2010). 


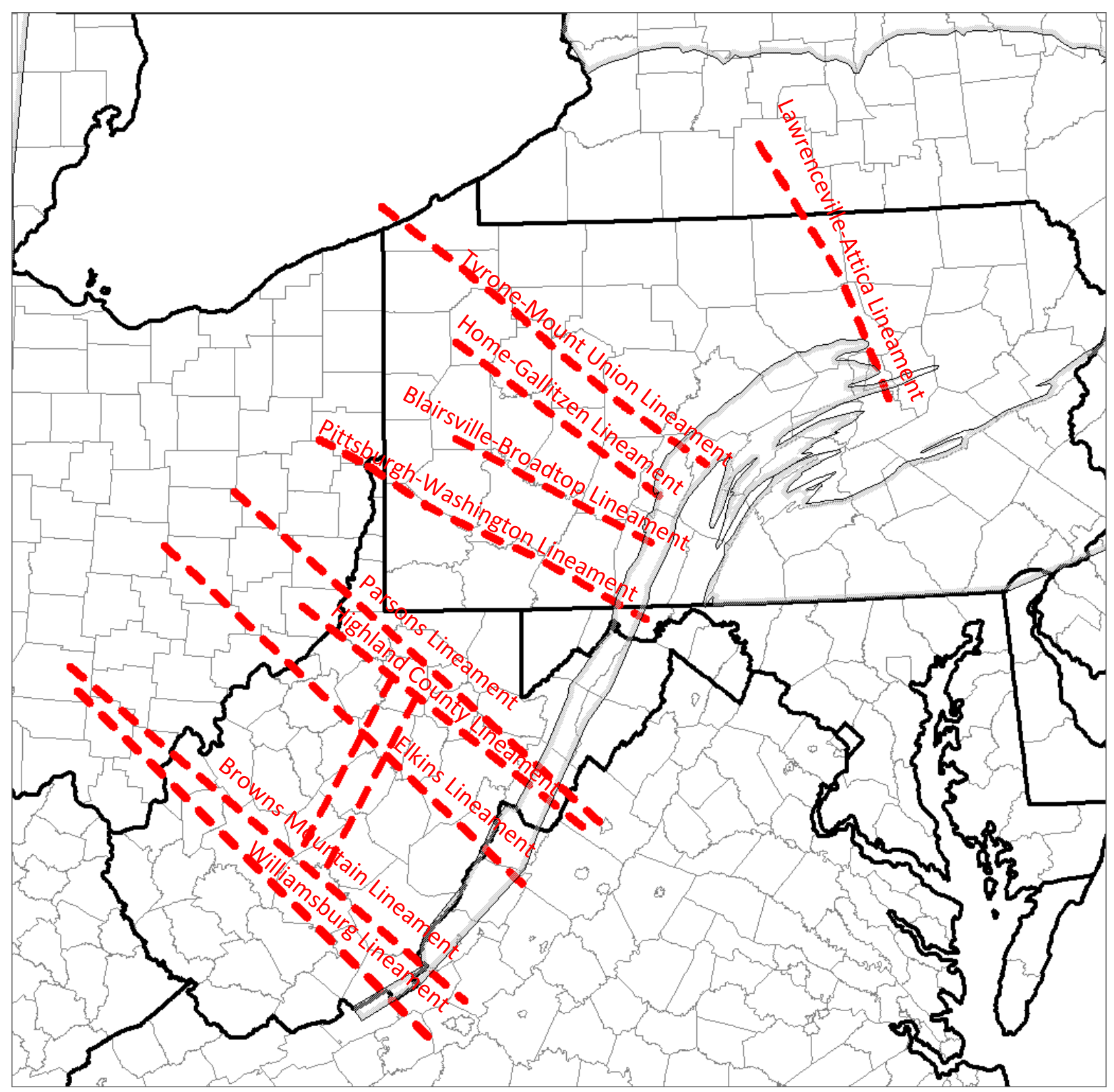

Figure 10. Map of major basement faults and lineaments (Modified from Southworth 1891, Zagorski et al 2012). 
In addition to the cross-strike thickening, there is a single line of major thinning (yellow dashed line on Figure 8). The thinning occurs in southwestern New York and trends into northwestern Pennsylvania and eastern Ohio where it wraps into southern West Virginia and

continues to the southwest. The thickness of the Marcellus in this area ranges from 20 feet $(6 \mathrm{~m})$ at maximum to 10 feet $(3 \mathrm{~m})$ at minimum. In Grant and Pocahontas Counties, WV, there is an isolated area of thickening to about 160-220 feet (48.8 - 67.1 m).

\section{UNION SPRINGS MEMBER ISOPACH}

The Union Springs (Figure 11) is the lowest member of the Marcellus Shale. It is generally identified by the Cherry Valley Limestone capping the formation. It also displays a higher gamma-ray reading than the Oatka Creek above. The body of the formation strikes $\mathrm{N} 45^{\circ} \mathrm{E}$ with the thickest portion, approximately 120 feet $(36.6 \mathrm{~m})$ thick, occurring near the study's eastern edge in northeastern Pennsylvania in Erie County. From this thick, the shale pinches out in northwestern Pennsylvania. The Union Springs also pinches out in New York, along the study's northern edge. Likewise, in West Virginia the thickest portion of the shale is approximately 60 feet $(18.3 \mathrm{~m})$ to the southeast, and thins to less than 10 feet in western West Virginia and southeastern Ohio. Another pinch-out occurs in West Virginia, and encompasses much of Mason, Cabell, Putnam, and Kanawha counties. 


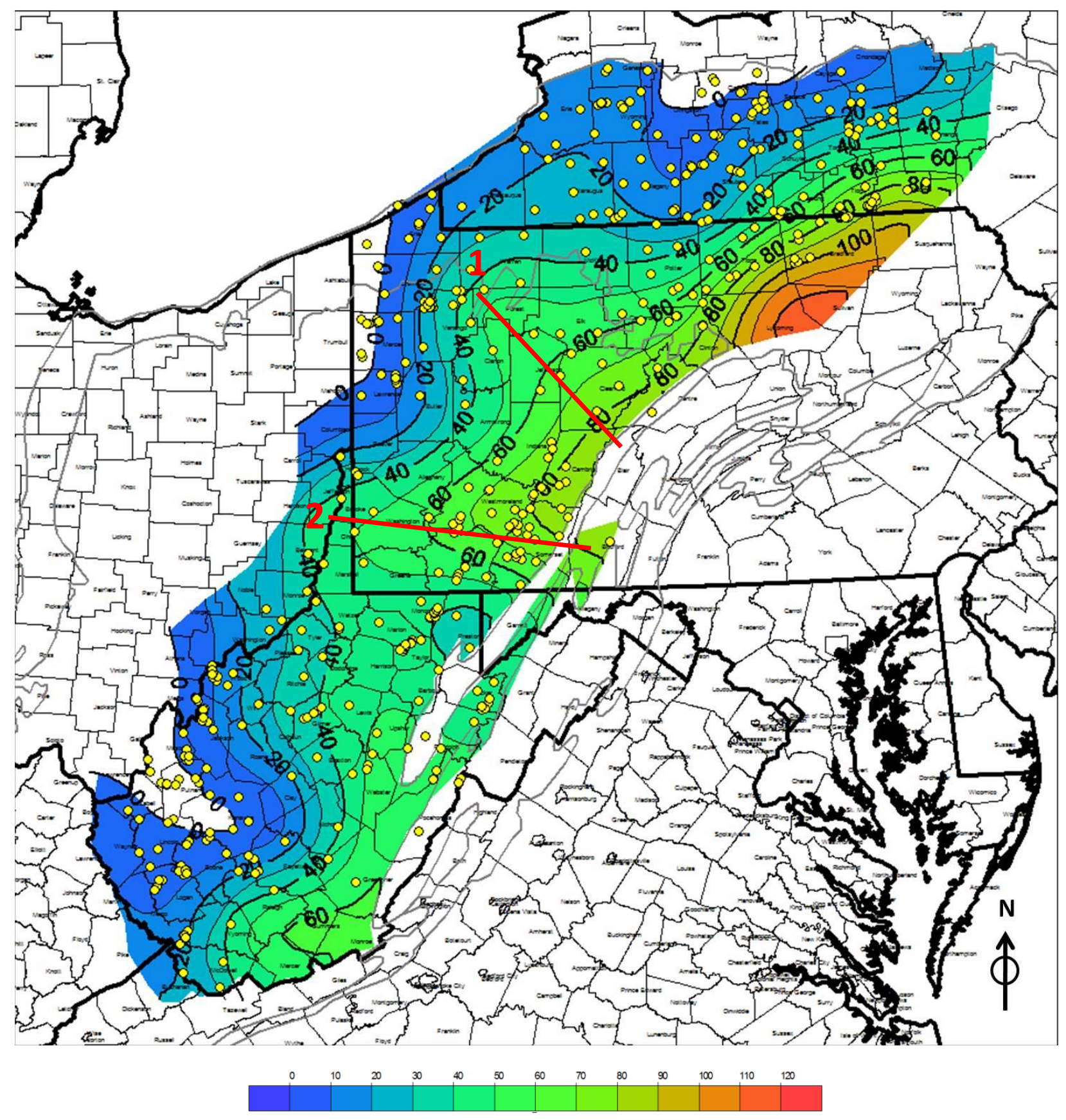

Figure 11. Isopach Map of the Union Springs member of the Marcellus Shale. Contour interval is 10 feet. 


\section{CHERRY VALLEY MEMBER ISOPACH}

The Cherry Valley (Figure 12) is the middle limestone member of the Marcellus Shale. The Cherry Valley Limestone is easily identified on logs by a gamma-ray reading of less than 100 API. The body of the formation strikes $\mathrm{N} 45^{\circ} \mathrm{E}$ and wraps due east in the northern portion of PA. The thickest portion, approximately 12 feet $(3.66 \mathrm{~m})$ thick, occurring near the study's western edge in southwestern Pennsylvania in Beaver County and another thick occurs in north central Pennsylvania in Potter County. In West Virginia the thickest portion of the limestone is approximately 8 feet $(2.44 \mathrm{~m})$ throughout the central portion of the state. The limestone thins both to the eastern and western portion of the study area in West Virginia, Pennsylvania, and New York. The Cherry Valley also pinches out in New York along the study's northern edge. 


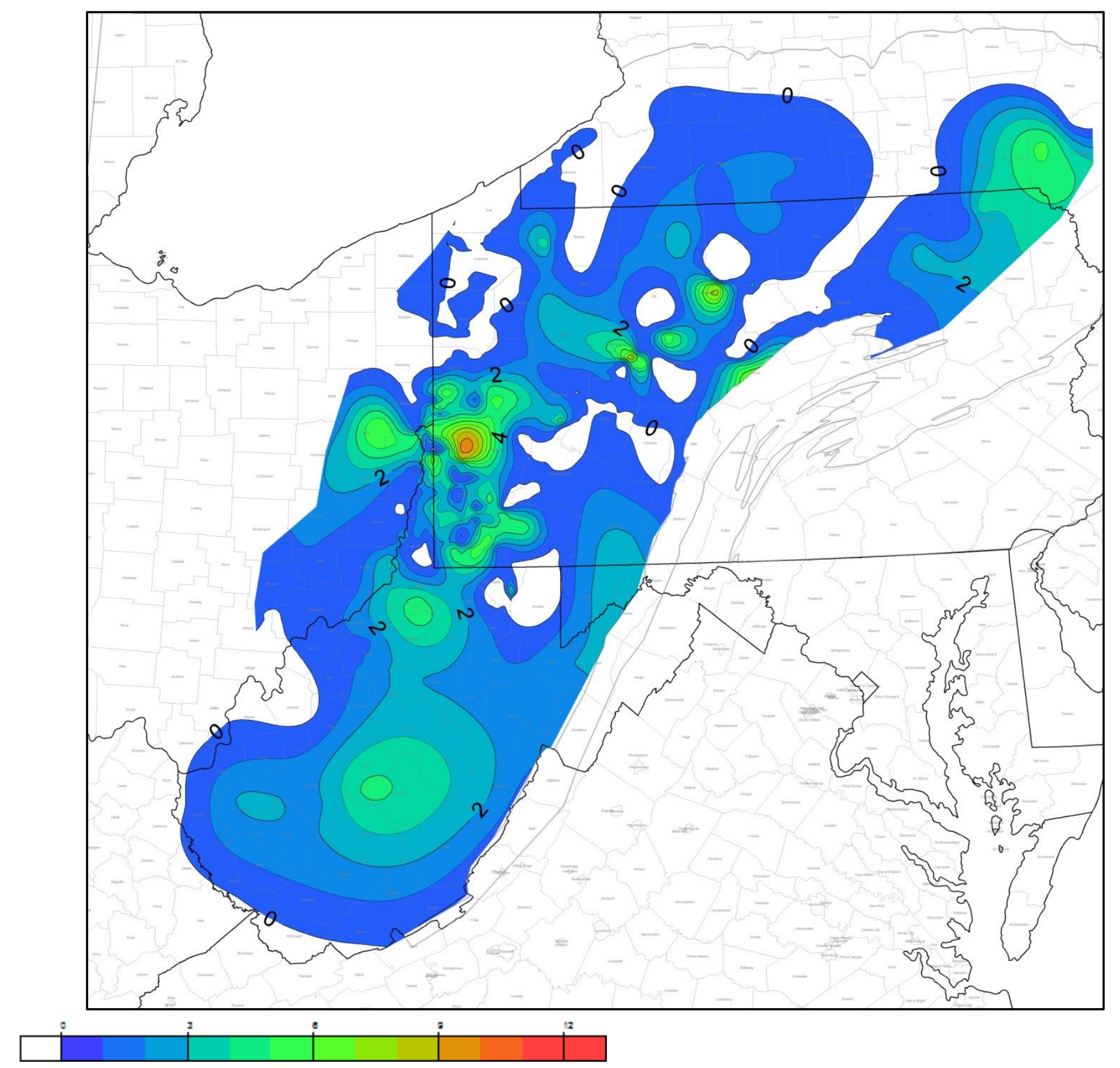

Figure 12. Isopach map of the Cherry Valley Limestone of the Marcellus Shale. Contour interval is 10 feet. 


\section{OATKA CREEK MEMBER ISOPACH}

Figure 13 is the isopach map generated for the Oatka Creek, which is the upper member of the Marcellus Shale. The depocenter of the formation strikes N45E with the thickest portion approximately 100 feet (30.5 m) thick near the study's northeastern edge in Pennsylvania and New York. From this thick the unit thins to less than 10 feet $(3 \mathrm{~m})$ in western Pennsylvania and eastern Ohio. In West Virginia, the thickest portion of the shale is approximately 60 feet (18.3 m) in southeastern West Virginia. The shale thins to less than 20 feet to the west in southeastern Ohio. The thinning of the Oatka Creek follows a similar trend to that of the Union Springs member.

This shale member displays 3 cross-strike features that are once again lobe-shaped. The first cross-strike feature occurs in southern New York and strikes to the northwest. Due to the strike, this feature correlates to the Lawrenceville-Altica Lineament. The lobe encompasses most of Steuben County, NY, and is over 20 feet $(6.1 \mathrm{~m})$ thick as it extends into Ontario and Livingston Counties, NY, where it thins to less than 10 feet $(3 \mathrm{~m})$. The second feature occurs in central Pennsylvania and strikes northwest extending into southwestern New York; it correlates with the Tyronne-Mount Union Lineament. The thickest portion of the feature is approximately 30 feet (9.1 m) thick in central PA and thins to less than 20 feet $(6.1 \mathrm{~m})$ in northwestern PA. The third feature occurs in northern West Virginia and correlates with the Parsons and Highland County Lineaments. The thickest portion of the feature is approximately 40 feet $(12.19 \mathrm{~m})$ thick in northern West Virginia and thins to less than 20 feet $(6.1 \mathrm{~m})$ in southeastern Ohio. 


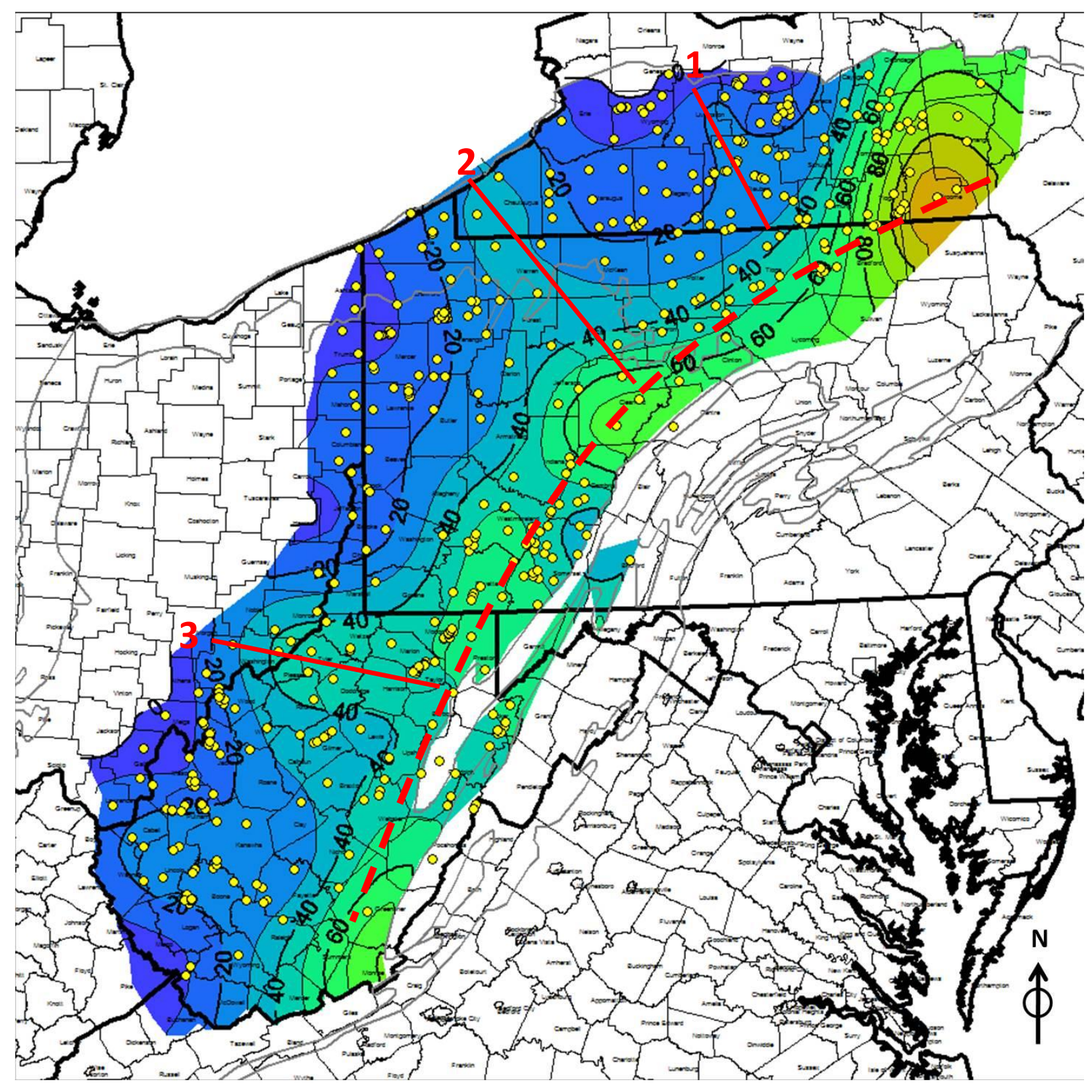

$\begin{array}{llllllllllll}0 & 10 & 20 & 30 & 40 & 50 & 60 & 70 & 80 & 90 & 100 & 110\end{array}$

Figure 13. Isopach Map of the Oatka Creek Member of the Marcellus Shale. The reddashed line represents the main body of the member and the red solid lines represent cross-strike features. Contour interval is 10 feet. 


\section{MAHANTANGO FORMATION ISOPACH}

Figure 14 is the isopach map for the Mahantango Formation. The body of the formation strikes N45E. The thickest portion of the formation is 1600 feet $(487.7 \mathrm{~m})$ in northeastern Pennsylvania and south-central New York with the very thickest portion located in Broome County, NY. As the formation is traced to the west the thickness thins to less than 100 feet $(30.5$ $\mathrm{m})$.

One cross-strike thickness features are apparent from the isopach map. It occurs in south central New York and strikes due north. This feature correlates loosely with the LawerencevilleAltica Lineament, and ranges in thickness from 1300 feet (396.2 m) to less than 1200 feet (365.8 $\mathrm{m})$. 


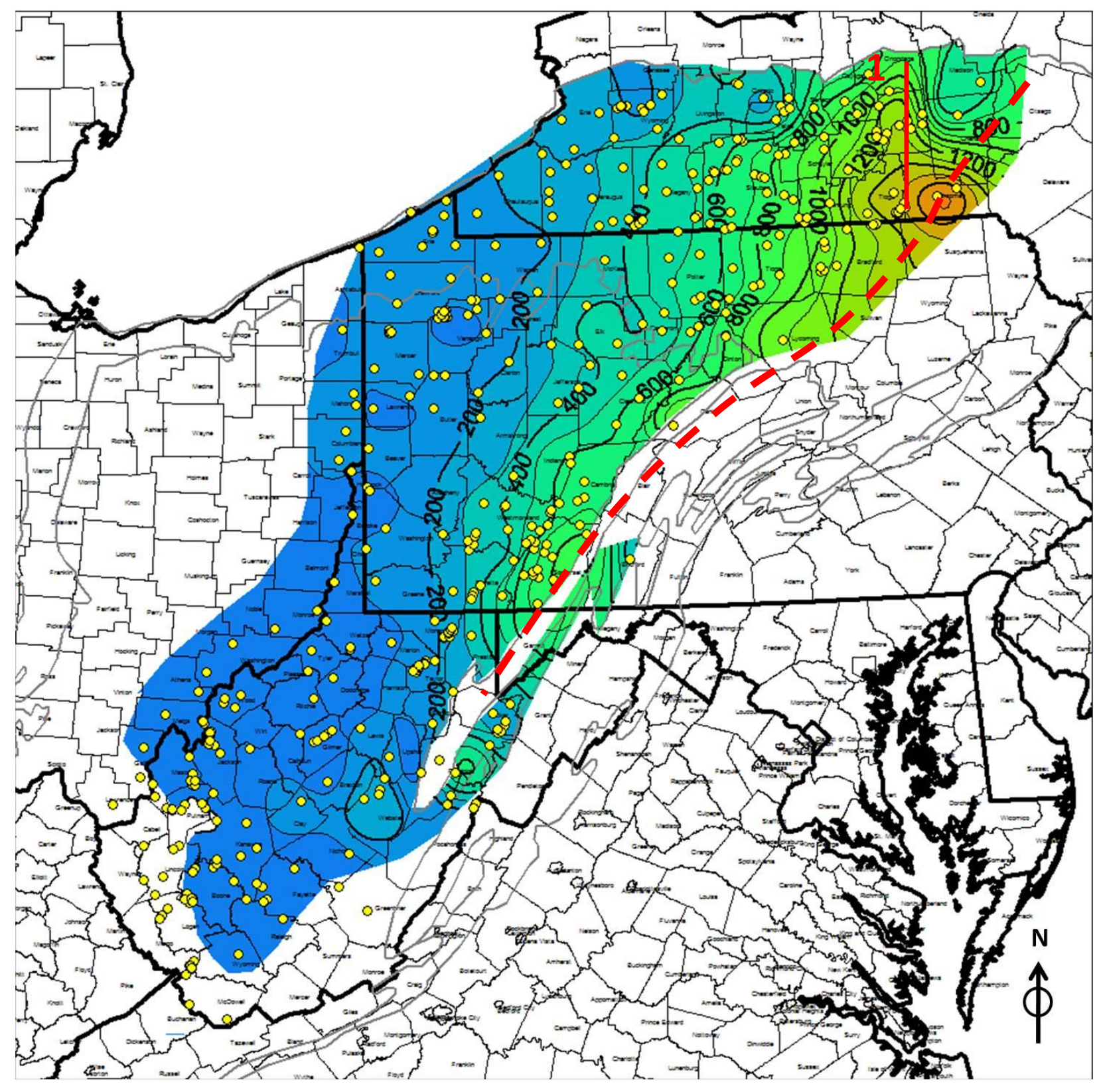

$\begin{array}{llllllllllllllllll}0 & 100 & 200 & 300 & 400 & 500 & 600 & 700 & 800 & 900 & 1000 & 1100 & 1200 & 1300 & 1400 & 1500 & 1600 & 1700\end{array}$

Figure 14. Isopach map of the Mahantango Shale the red-dashed line represents the main body of the formation. 


\section{STRATIGRAPHIC CROSS SECTIONS}

Within the study area 8 dip lines and 2 strike lines were correlated (Fig 15). Dip section A-A' crosses southern New York and begins in Chautauqua County, NY and ends in Tioga County, NY. Section B-B' crosses northern Pennsylvania and begins in Erie County, PA and ends in Clinton County, PA. Section C-C' crosses from eastern Ohio into central Pennsylvania and begins in Trumbull County, $\mathrm{OH}$ and ends in Cambria County, PA. Section D-D' crosses from eastern Ohio into south central Pennsylvania and begins in Jefferson County, PA and ends in Somerset County, PA. Section E-E' crosses from eastern Ohio to eastern West Virginia and begins in Monroe County, OH and ends in Tucker County, WV. Section F-F' crosses from south eastern Ohio into central West Virginia and begins in Athens County Ohio and ends in Randolph County, WV. Section G-G' crosses from southeastern Ohio into southern West Virginia and begins in Gallia County, OH and ends in Greenbrier County, WV. Section H-H' crosses from southwestern West Virginia to south central West Virginia and begins in Cabell County, WV and ends in McDowell County, WV.

Strike line I-I' extends from New York southward into Ohio and ends in southwestern West Virginia. The line begins in Erie County NY and ends in Cabell County, West Virginia. Strike line J-J' extends from New York southward into Pennsylvania and ends in south-central West Virginia. The line begins in Broome County, NY and ends in Mingo County, WV. 


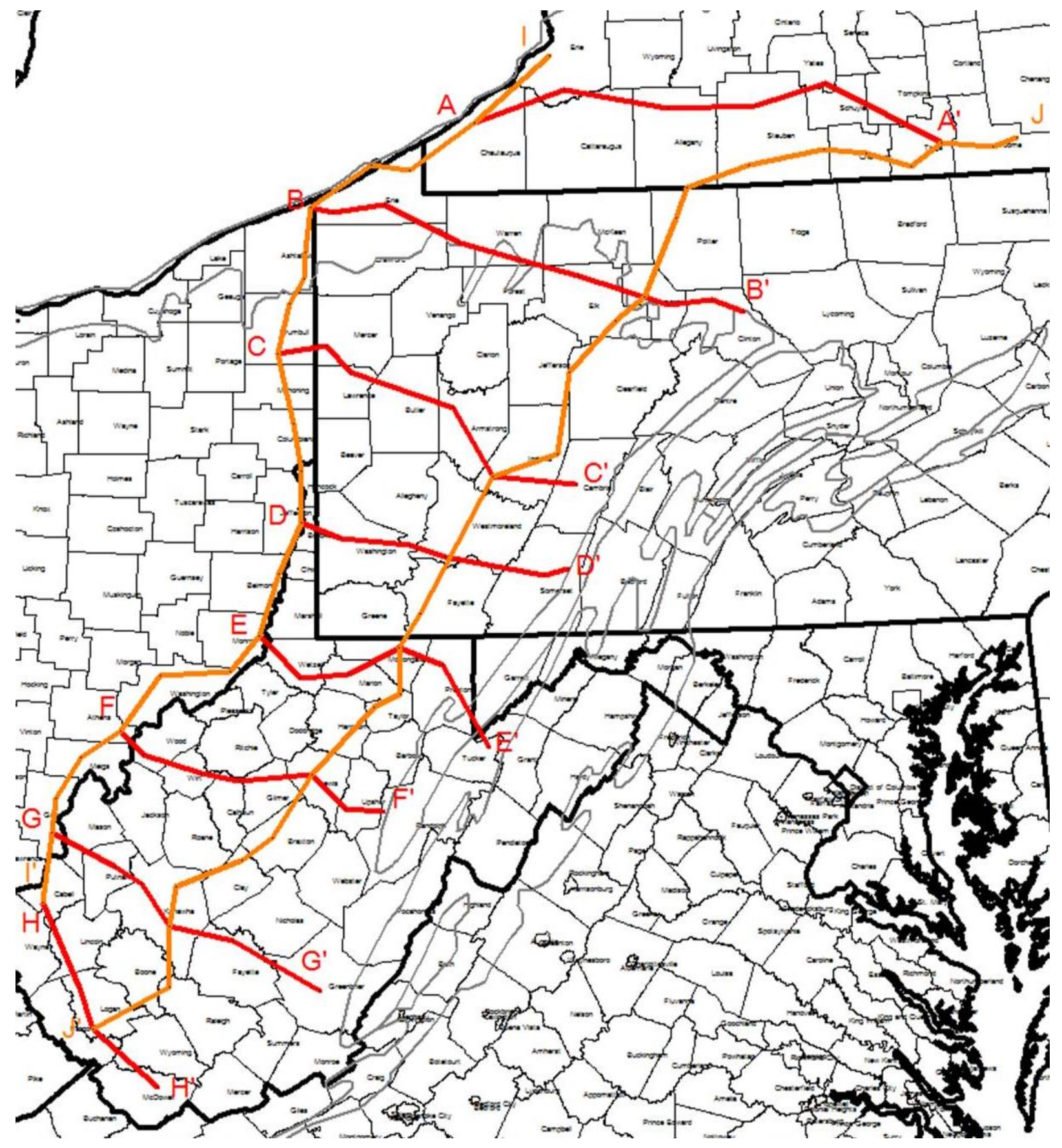

Figure 15. Regional map showing the locations of all cross sections within the study area. 


\section{A-A' CROSS SECTION}

The Marcellus and Mahantango formations show a general west to east thickening trend

(Figure 16). The Union Springs member of the Marcellus Shale pinches out on top of the Oatka Creek in Chautauqua County and Erie County, NY. From Tompkins County, NY east, the Union Springs, which exceeds the thickness of the upper Oatka Creek. 


\section{B-B' CROSS SECTION}

The Marcellus and Mahantango formations show a general west to east thickening trend (Figure 17). In Erie County, PA, and westward, the Union Springs member thins drastically and pinches out. East of Erie County, PA, the Union Springs thickens drastically to about 100' thick. The Oatka Creek Member thickness stays relatively constant from west to east, until Elk County, PA where it thickens eastward. 


\section{C-C' CROSS SECTION}

The Marcellus and Mahantango formations show a general west to east thickening trend (Figure 18). In Lawrence County, PA, and westward, the Union Springs member thins drastically and pinches out. East of Lawrence County, PA, the Union Springs begins to thicken. The Oatka Creek Member thickness stays relatively constant from west to east, until Armstrong County, PA, where it continues to thicken eastward. 


\section{D-D' CROSS SECTION}

The Marcellus and Mahantango formations show a general west to east thickening trend (Figure 19). The Union Springs Member follows a general west to east thickening trend. The Oatka Creek Member is thin in Jefferson County, $\mathrm{OH}$, but as the member trends eastward, the thickness stays relatively constant, only narrowly thinning in Westmoreland County, PA. 


\section{E-E' CROSS SECTION}

The Marcellus and Mahantango formations show a general west to east thickening trend (Figure 20). The Union Springs Member thickness stays relatively constant from west to east until Preston County, WV, where it thickens eastward. The Oatka Creek Member follows a general west to east thickening trend until Mason County, WV, then the member maintains a relatively constant thickness eastward. 


\section{F-F' CROSS SECTION}

The Marcellus and Mahantango formations show a general west to east thickening trend (Figure 21). The Union Springs Member pinches out west of Wirt County, WV. Eastward, the Union Springs Member maintains a relatively constant thickness, only thinning briefly in Lewis County, WV. The Oatka Creek Member is very thin in the west, but follows a general west to east thickening trend eastward of Wirt County, WV. 


\section{G-G' CROSS SECTION}

In this cross section, the Mahantango Formation is very thin, and barely thickens eastward (Figure 22). The Marcellus Shale remains thin until Fayette County, WV where it thickens to the east. The Union Springs Member is not present in parts of and west of Kanawha County, WV. The Oatka Creek Member remains relatively thin until Fayette County, WV, Where it thickens to the east. 


\section{H-H' CROSS SECTION}

The Mahantango Shale is absent in the western portion of this cross section (Figure 23). The thickness of the Marcellus Shale remains relatively constant from west to east. The Union Springs member is absent from this cross section, leaving only the Oatka Creek Member. 


\section{I-I' CROSS SECTION}

From north to south the Marcellus Shale stays a relatively constant thickness until Jefferson County, $\mathrm{OH}$ where it thickens drastically and subsequently thins again in Washington County, OH (Figure 24). The Mahantango Formation starts thick in the north and undergoes a north to south thinning trend. The Union Springs member follows the same trend as the total Marcellus Formation in that it is very thin to nonexistent from north to south until Jefferson County, $\mathrm{OH}$ where it thickens and subsequently thins in Washington County, $\mathrm{OH}$ and stays that way southward. The Oatka Creek follows the same trend as the Union Springs and total Marcellus Formation. 


\section{J-J' CROSS SECTION}

The Marcellus Shale is very thick in the northern section of the study area; as it trends southward it fluctuates gradually between thick and thin until it gradually thins out in the south (Figure 25). The Mahantango Formation starts thick in the north and undergoes a north to south thinning trend. The Union Springs member follows the same trend as the total Marcellus Formation in that it is thick in the north, gradually fluctuates between thick and thinner, and thins out completely in the south. The Oatka Creek follows the same trend as the Union Springs and total Marcellus Formation. 


\section{PETROLEUM RESERVOIR ISOPACH MAPS}

\section{GAMMA-RAY ISOPACH MAPS}

One major purpose of this study is to correlate typical gamma-ray values to the organicrichness of shale, although admittedly gamma-ray measurements act only as a proxy for the total organic content in the rock. The following maps were generated to reflect the organic content (or lack thereof) in the rock column.

\section{Gamma-Ray $<100$ API}

Figure 26 is a net thickness map of the Marcellus Shale with gamma-ray values less than 100 API within the study area. This map represents the net thickness of limestone and some calcareous shale within the Marcellus Shale. The body of this formation is thickest along the western edge of the study area in Pennsylvania and along the northern edge in New York. The thickest portion of this map is approximately 14 feet $(4.27 \mathrm{~m})$ thick, and occurs in Washington, Allegheny, Beaver and Butler Counties in Pennsylvania. 


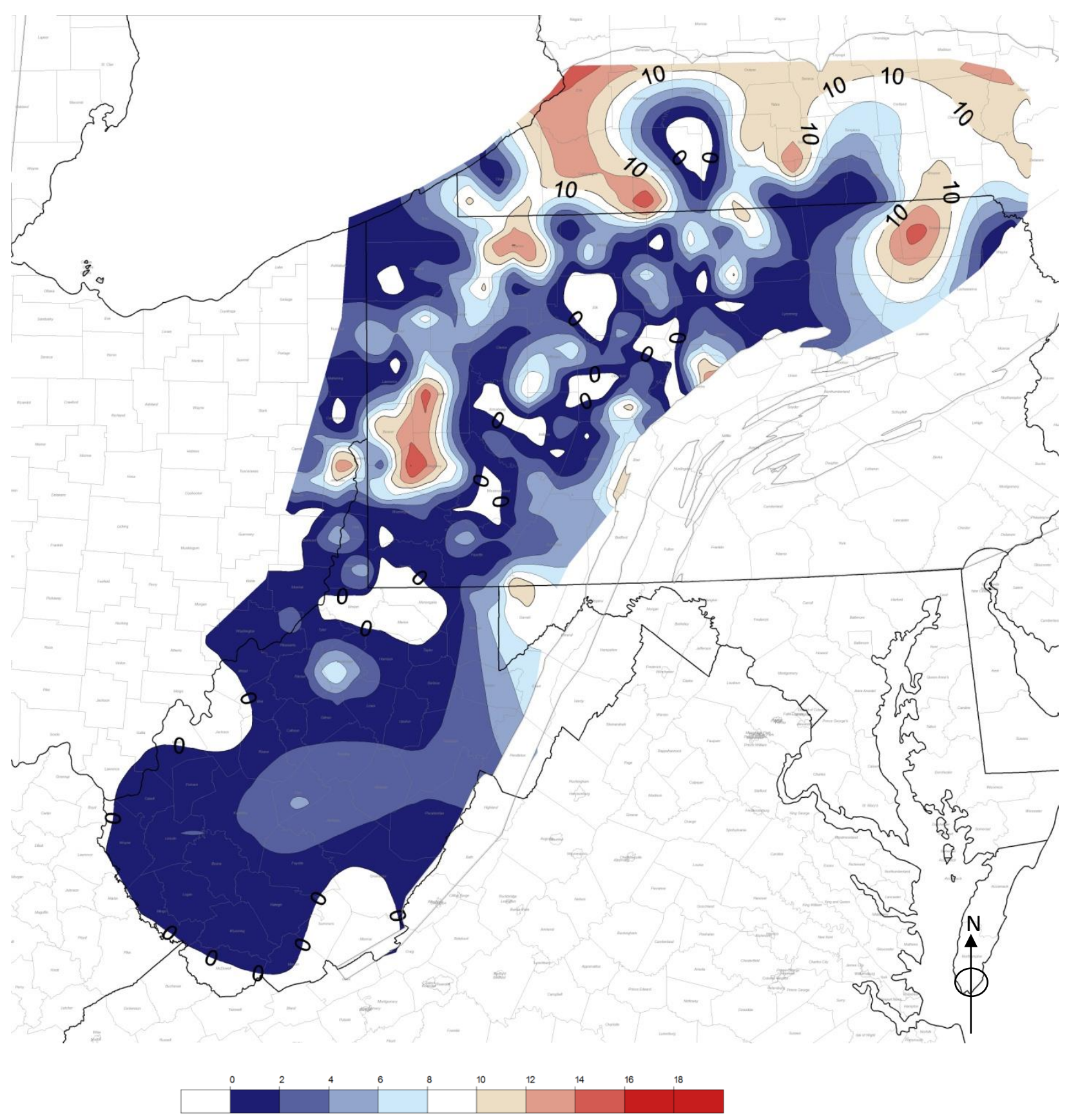

Figure 26. Marcellus net thickness less than 100 API (Limestone) Map 


\section{Gamma-Ray Between 100-180 API}

Figure 27 is a net thickness map of the Marcellus Shale with gamma-ray values between 100 to 180 API within the study area. This map represents the net thickness of gray shale and siltstone or all nonorganic rock within the Marcellus Shale. The body of these strata is thickest along the eastern edge of the study area with many isolated thicknesses throughout Pennsylvania. The thickest portion of this map is approximately 175 feet $(53.34 \mathrm{~m})$ thick, and occurs in northeastern Pennsylvania closest to the source area. 


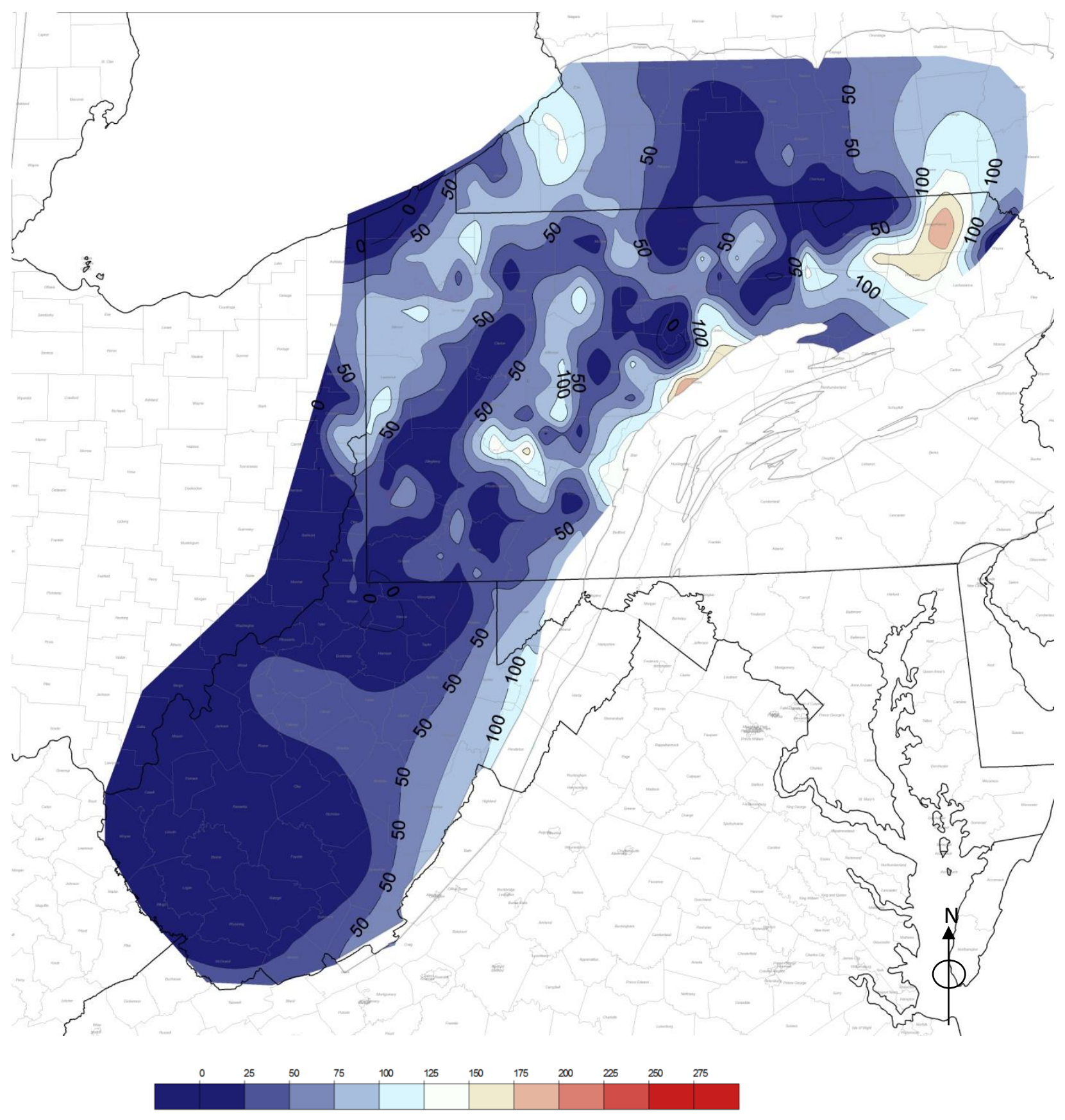

Figure 27. Marcellus net thickness between 100 and 180 API (Nonorganic Shale) 


\section{Gamma-Ray > 180 API}

Figure 28 is a net thickness map of the Marcellus Shale with gamma-ray values greater than 180 API within the study area, that is, organic-rich shale. All thickness contours greater than 50 feet (thickness of economic viability) are highlighted in gray. The body of these strata strike $\mathrm{N} 45^{\circ} \mathrm{E}$ with the thickest portion, approximately 200 feet $(70 \mathrm{~m})$ thick, occurring near the study's eastern edge in northeastern Pennsylvania. 


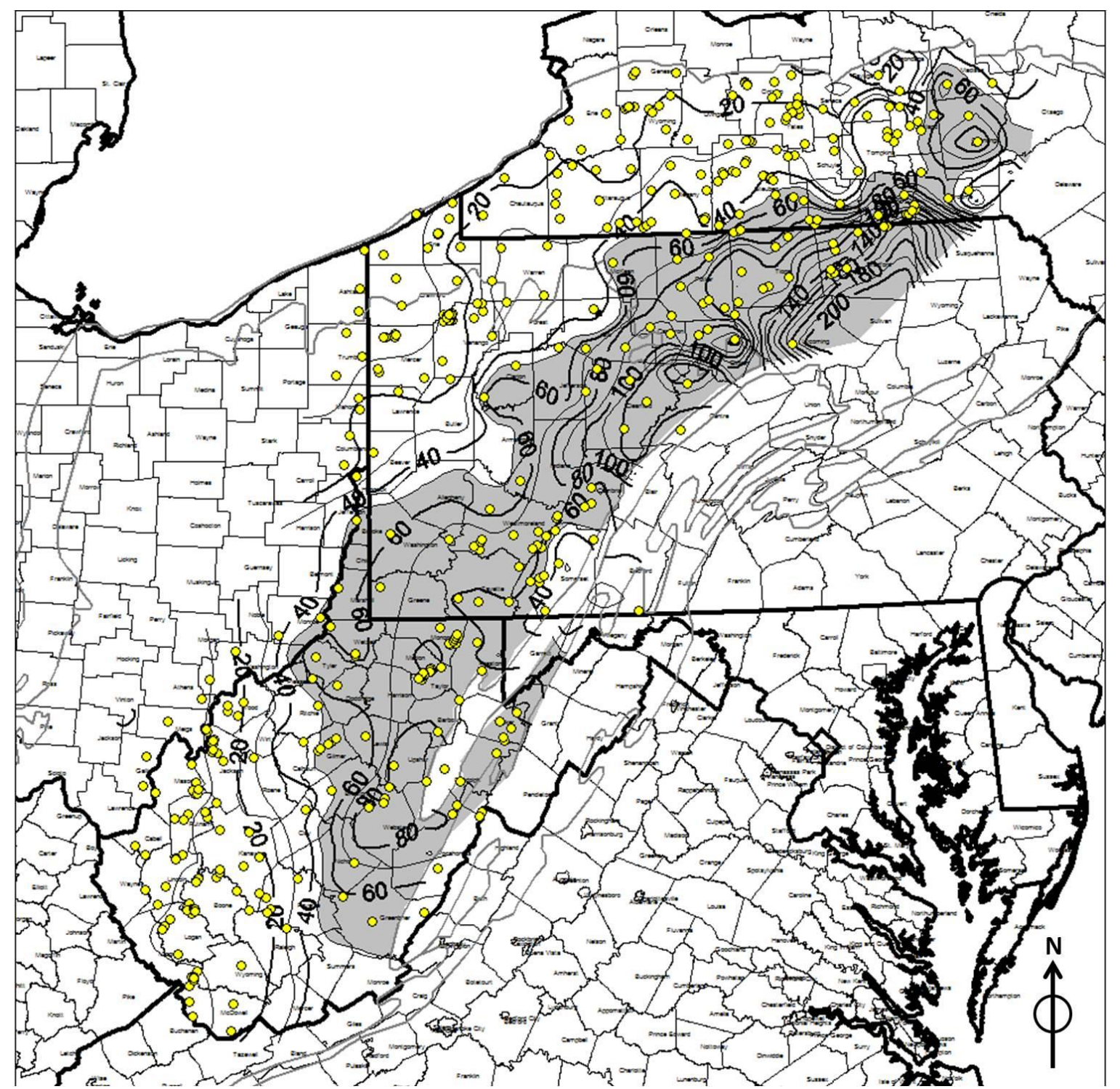

Figure 28. Marcellus net thickness map greater than 180 API. Everything shaded in gray represents a thickness $50 \mathrm{ft}$ and greater. 


\section{Gamma-Ray > 200 API}

Figure 29 is a net thickness map of the Marcellus Shale interval with gamma-ray values greater than 200 API within the study area. All thickness contours greater than 50 feet are highlighted in gray. The body of these strata strike $\mathrm{N} 45^{\circ} \mathrm{E}$ with the thickest portion, approximately 150 feet $(45.7 \mathrm{~m})$ thick, occurring near the study's eastern edge in northeastern Pennsylvania. 


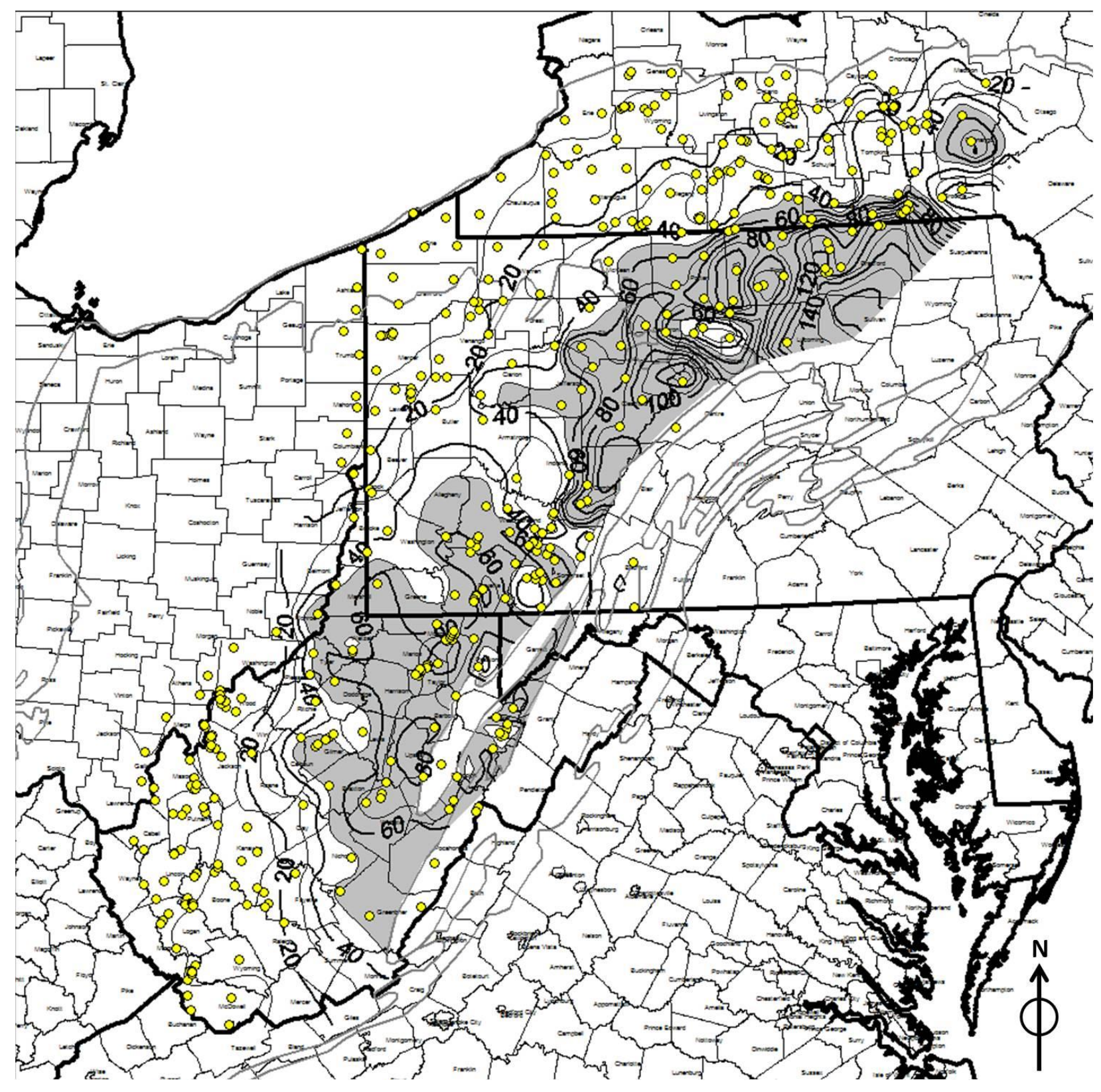

Figure 29. Marcellus net thickness map greater than 200 API. Everything shaded in gray represents a thickness $50 \mathrm{ft}$ and greater. 


\section{Gamma-Ray > 250 API}

Figure 30 is a net thickness map of the Marcellus Shale interval with gamma-ray values greater than 250 API within the study area. All thickness contours greater than 50 feet are highlighted in gray. A number of features are apparent from its distribution. The body of the formation strikes $\mathrm{N} 45^{\circ} \mathrm{E}$ with the thickest portion, approximately 70 feet $(21.3 \mathrm{~m})$ thick, occurring near the study's eastern edge in northeastern Pennsylvania and central West Virginia. There are several areas where the net thickness is greater than 50 feet. The first area is in northeastern PA and south-central NY. This area encompasses part of Bradford County, PA, and most of Tioga County, NY. The second area occurs in north central PA, but is most prevalent in Potter, Elk, and Jefferson Counties. The third area with net thickness greater than 50 feet occurs in southwestern PA and encompasses Fayette and Westmoreland Counties. The final area covers the largest surface area and occurs in central WV. 


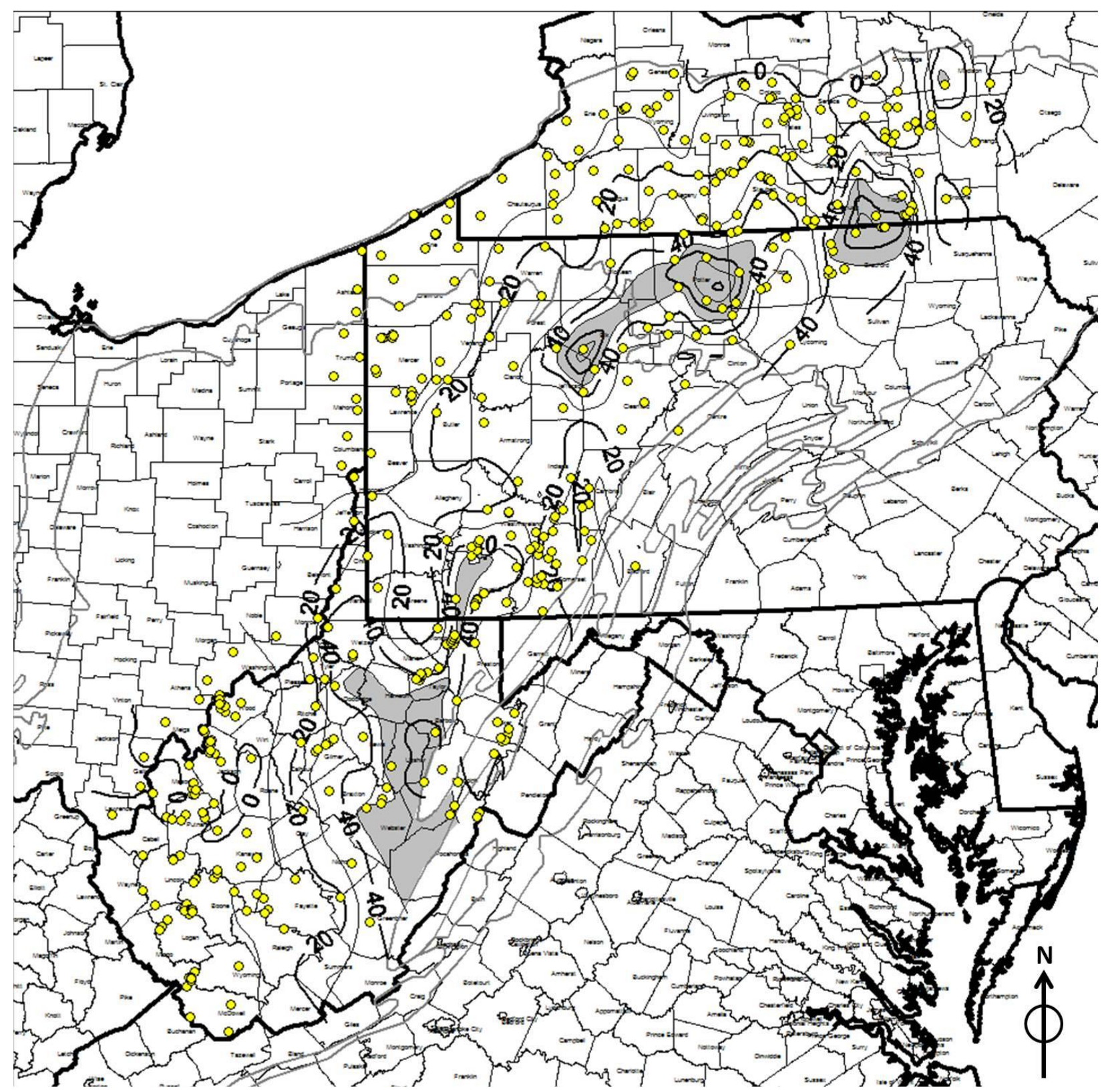

Figure 30. Marcellus net thickness map of feet greater than 250 API. Everything shaded in gray represents a thickness $50 \mathrm{ft}$ and greater. 


\section{Gamma-Ray > 300 API}

Figure 31 is a net thickness map of the Marcellus Shale Shale interval with gamma-ray values greater than 300 API within the study area, that is, shale most rich in organic matter. All thickness contours greater than 50 feet are highlighted in gray. A number of features are apparent from its distribution. The body of the formation strikes $\mathrm{N} 45^{\circ} \mathrm{E}$ with the thickest portion, approximately 60 feet $(18.3 \mathrm{~m})$ thick, occurring near the study's eastern edge in northeastern Pennsylvania. Only two small areas with greatest organic-richness exceed 50 feet in thickness. The first area occurs in Potter County, PA. The second area occurs in Barbour County, WV. There are also several zones of 0' net thickness with the first in New York just south of the outcrop belt. The second is an isolated area in central PA that occurs in the following counties: Indiana, Cambria, and Clearfield. The last area of 0' net thickness occurs in the southwestern side of West Virginia. 


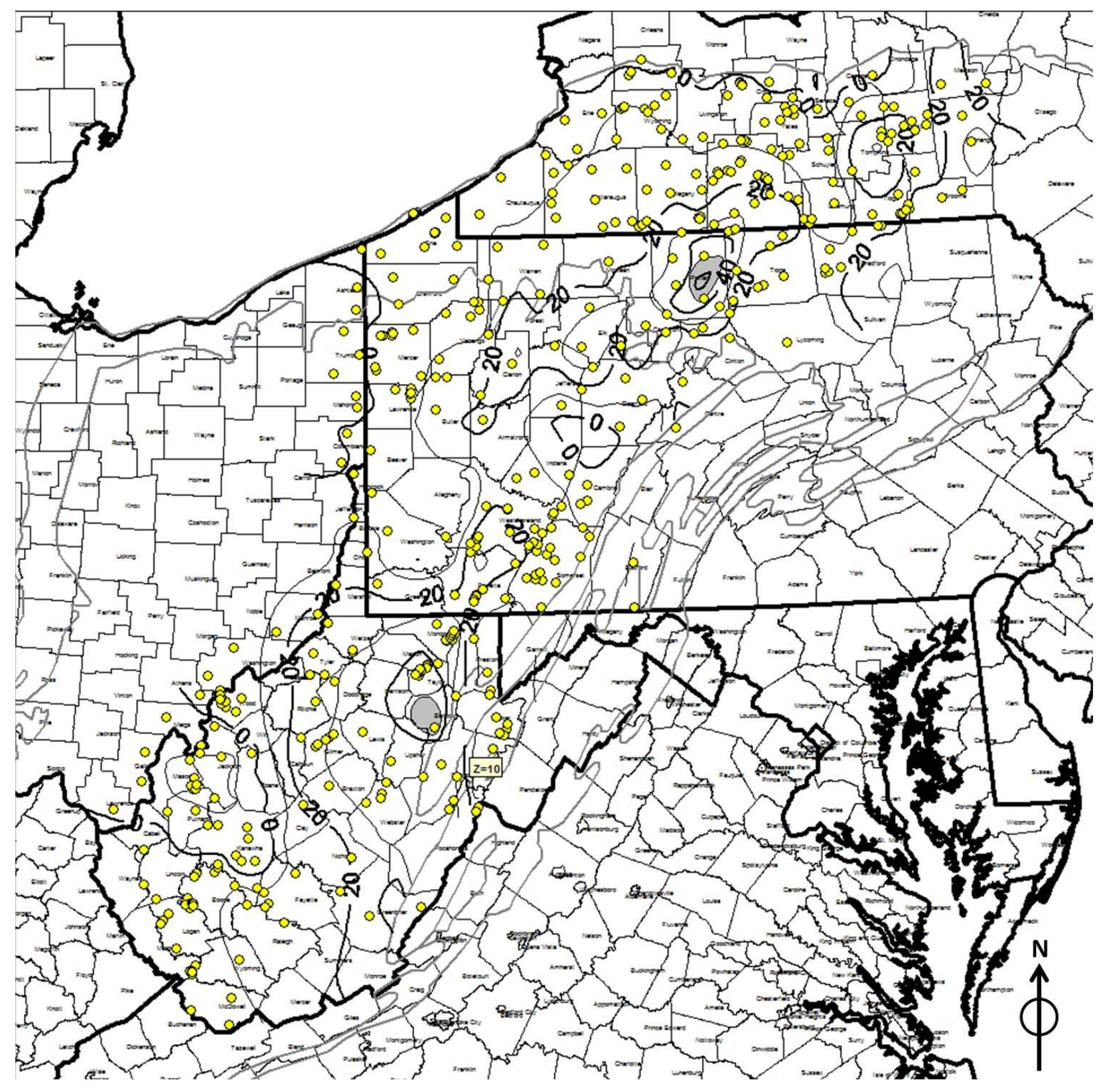

Figure 31. Marcellus net thickness map greater than 300 API. Everything shaded in gray represents a thickness $50 \mathrm{ft}$ and greater. 


\section{Average Gamm-Ray API}

Figure 32 is an average Gamma Ray API Map generated over the gross thickness of the Marcellus Shale. A few features are apparent from this map. The highest gamma ray values strike $\mathrm{N} 45^{\circ} \mathrm{E}$ across Pennsylvania and into southern New York. In West Virginia the highest gamma ray value trends northwest-southeast. Along the northeastern edge of the study area the average gamma ray is low. This matches the trend of the foreland bulge. 


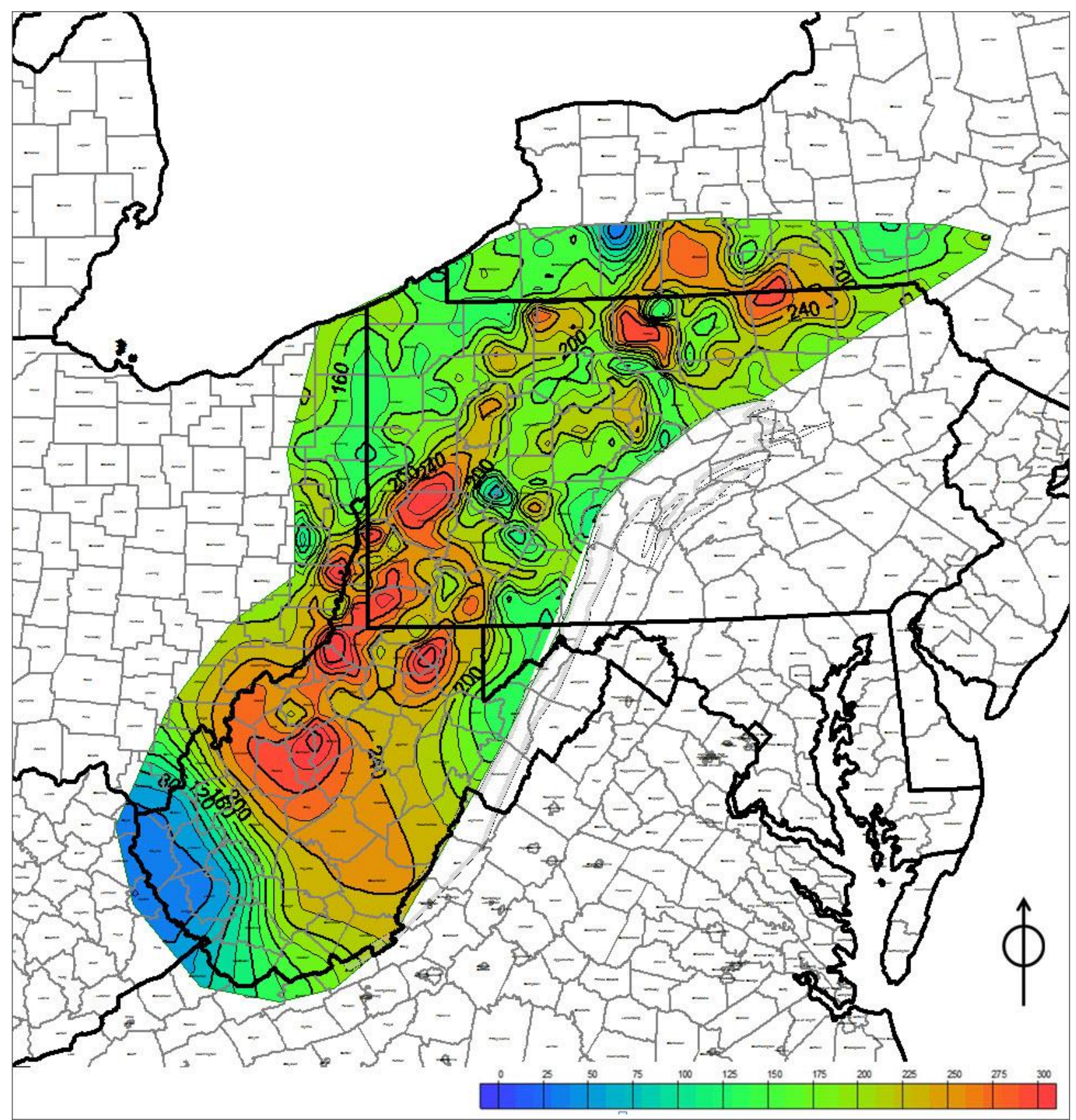

Figure 32. Average gamma-ray API Map of the Marcellus Shale Formation. 


\section{BULK-DENSITY ISOPACH MAPS}

Much like the gamma-ray, the bulk density can also act as a proxy for TOC. The following maps were generated for this purpose.

\section{Bulk-density less than $2.55 \mathrm{~g} / \mathrm{cc}$}

Figure 33 is a net thickness map of the Marcellus Shale with a bulk-density value of less than $2.55 \mathrm{~g} / \mathrm{cc}$, the density cutoff for organic-rich shale. The body of the formation strikes $\mathrm{N} 10^{\circ} \mathrm{E}$ with the thickest portion, approximately 70 feet $(20.3 \mathrm{~m})$ thick, occurring in Wetzel and Tyler Counties, WV, and Monroe County, OH. In addition to the area of greatest thickness, there are also two other thick areas. The first occurs in central Pennsylvania and has a thickness of 50 feet $(15.4 \mathrm{~m})$ and encompasses Jefferson County and parts of Clarion, Elk, and Armstrong Counties in PA. The second thick area occurs in south-central New York, with the thickest portion in Tioga County at approximately 50 feet $(15.4 \mathrm{~m})$ thick.

There are also several areas of 0 ' net thickness. The first occurs in northwest Pennsylvania in Erie and Crawford Counties. The second occurs in central Pennsylvania in Centre, Clinton and Clearfield Counties but this thin is based on one data point. 


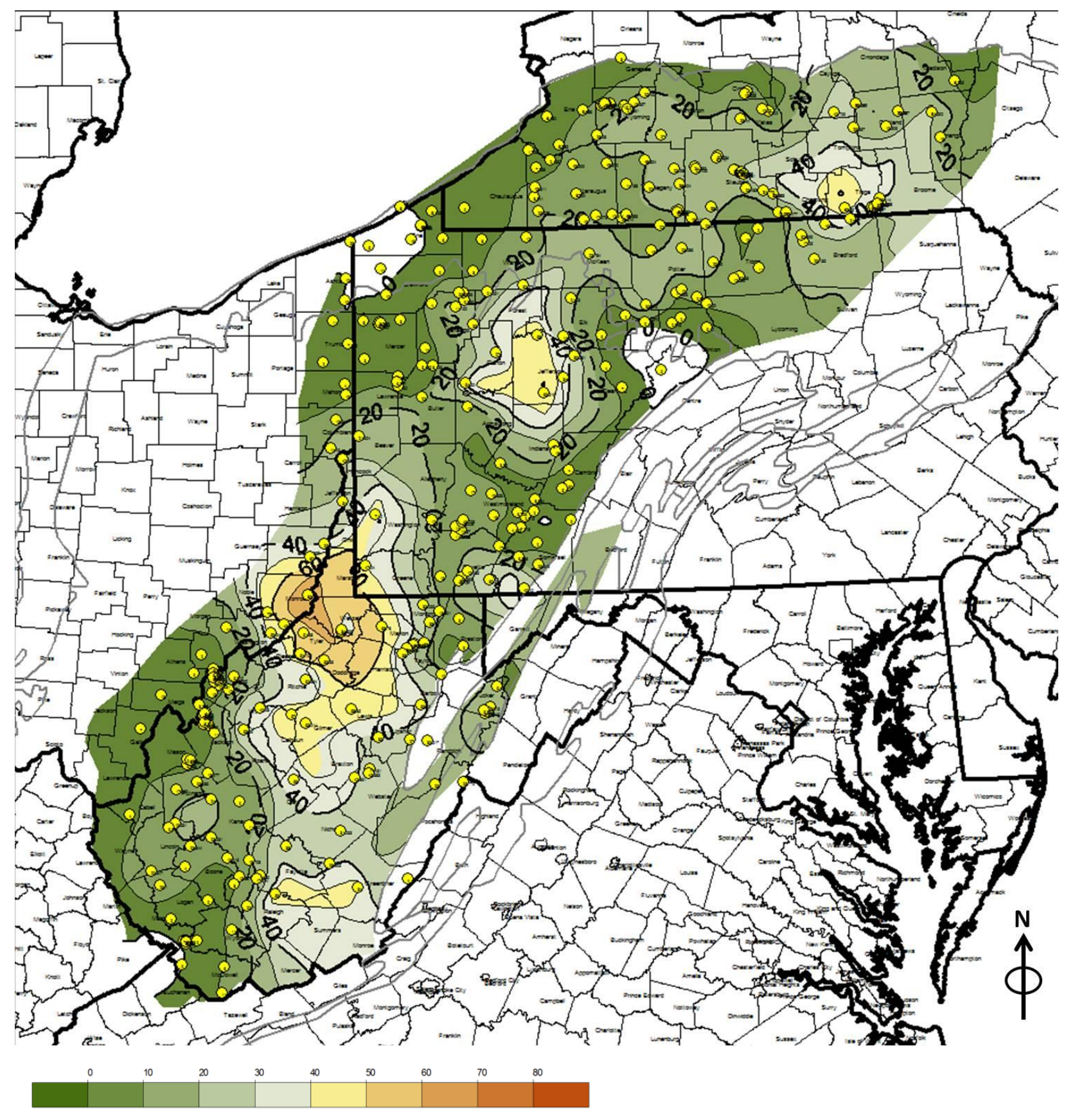

Figure 33. Marcellus bulk-density net thickness map of feet less than $2.55 \mathrm{~g} / \mathrm{cc}$ 


\section{Bulk-density less than $2.4 \mathrm{~g} / \mathrm{cc}$}

Figure 34 is a net thickness map of the Marcellus Shale with a bulk-density value of less than $2.4 \mathrm{~g} / \mathrm{cc}$ within the study area. A number of features are apparent from its distribution. The body of the formation strikes $\mathrm{N} 10^{\circ} \mathrm{E}$ with the thickest portion, approximately 70 feet $(21.3 \mathrm{~m})$ thick, occurring in Monroe County, Ohio. In addition to the thickest interval, there is another thick area that strikes due north. In central PA the thickest portion is approximately 40 feet $(12.32 \mathrm{~m})$ thick. The net thickness is $0^{\prime}$ across the northern portion of the study area in small isolated areas within central PA, and southwestern WV. 


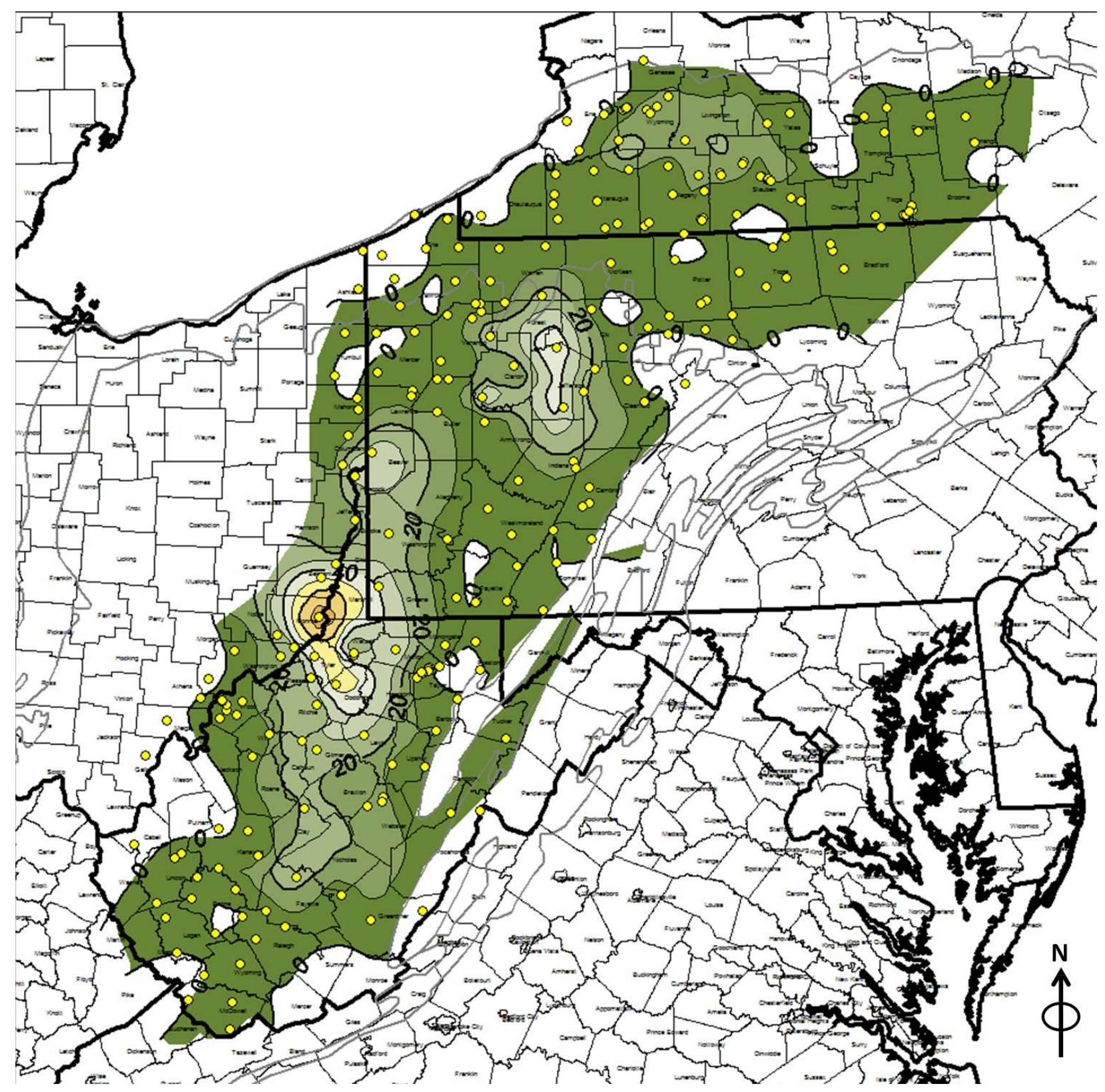

\begin{tabular}{|l|l|l|l|l|l|l|l|l|l|}
\hline 0 & 10 & 20 & 30 & 40 & 50 & 60 & 70 & 80 \\
\hline
\end{tabular}

Figure 34. Marcellus bulk-density net thickness map of feet less than $2.4 \mathrm{~g} / \mathrm{cc}$ 


\section{Bulk-density less than $2.35 \mathrm{~g} / \mathrm{cc}$}

Figure 35 is a net thickness map of the Marcellus Shale interval with a bulk-density value of less than $2.35 \mathrm{~g} / \mathrm{cc}$ within the study area. A number of features are apparent from its distribution. The body of the formation strikes $\mathrm{N} 10^{\circ} \mathrm{E}$ with the thickest portion, approximately 60 feet $(18.5 \mathrm{~m})$ thick, occurring in Monroe County, Ohio. In addition to the thickest interval, there is another thick area that occurs in Jefferson and Forest County, PA with the thickest portion approximately 40 feet $(12.32 \mathrm{~m})$ thick. The net thickness reaches 0 ' in northeast Ohio, northwest Pa, and southwest NY. The 0' thickness wraps around the northern edge of the study area in New York. in central and northeast PA the net thickness reaches 0' with a strike of $\mathrm{N} 30^{\circ} \mathrm{W}$. In southern West Virginia, the net thickness reaches $0^{\prime}$ in the west and south side of the state. 


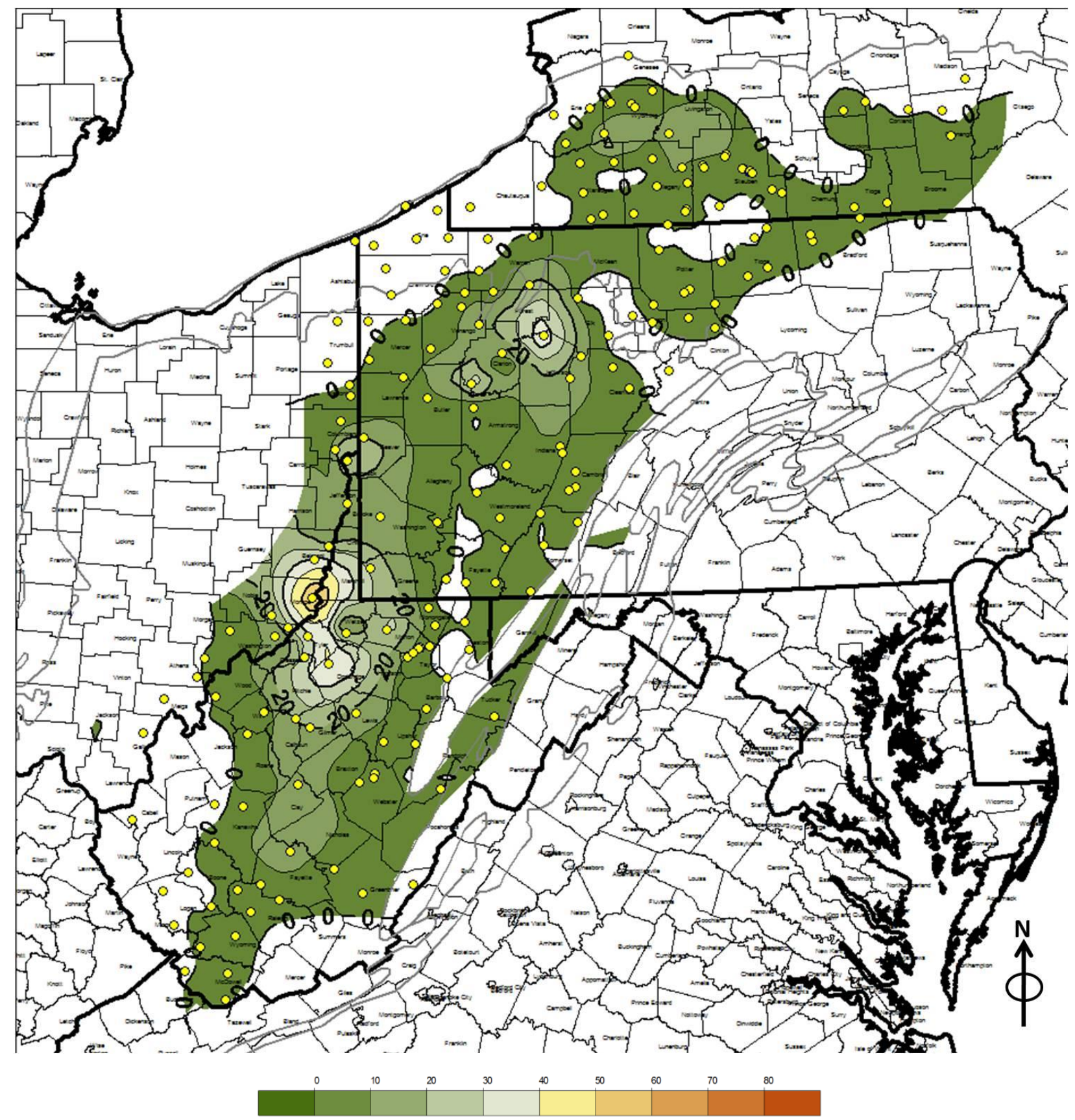

Figure 35. Marcellus bulk-density net thickness map of feet less than $2.35 \mathrm{~g} / \mathrm{cc}$ 


\section{SEQUENCE STRATIGRAPHY}

A sequence stratigraphic model of the Marcellus Shale was generated in order to map the stratigraphy at a fine detail - for better correlations across the basin and a clearer understanding of the deposition systems through time. This model can also be used along with the petroleum isopach maps to help select drillable targets within the Marcellus Shale. The maps in this section follow the transgressive - regressive model of sedimentation (Catuneanu 2006, Embry 2009, Lash 2011) as applied to the Marcellus Shale. This model works well for a log data set because it relies on correlations of regression surfaces and flooding surfaces, surfaces easily identifiable on well logs.

A maximum regressive surface is a surface that marks the end of regression and a maximum transgressive surface is a surface that marks the end of transgression (Helland-Hansen and Martinsen 1996, Catuneanu 2006, Lash 2010). Large-scale peaks in the gamma-ray represent maximum flooding surfaces whereas troughs represent maximum regressive surfaces. A sequence begins with a maximum regressive surface and extends past the maximum flooding surface to the next maximum regressive surface higher in the section. It is assumed that the intervening sequence represents one time slice.

In this study each surface was correlated across the study area, and isopach maps showing the thickness of each sequence and systems tract were constructed. Figure 36 is a type log displaying the Transgressive-Regressive sequences, systems tracts, and major surfaces marked on the log. This type log displays three major T-R sequences each composed of a transgressive systems tract at the base and a regressive systems tract at the top of the sequence. Figure 37 is a map displaying the location of the sequence stratigraphic type-section and the well locations. Figure 38 is the cross section displaying all sequences and systems tracts. 


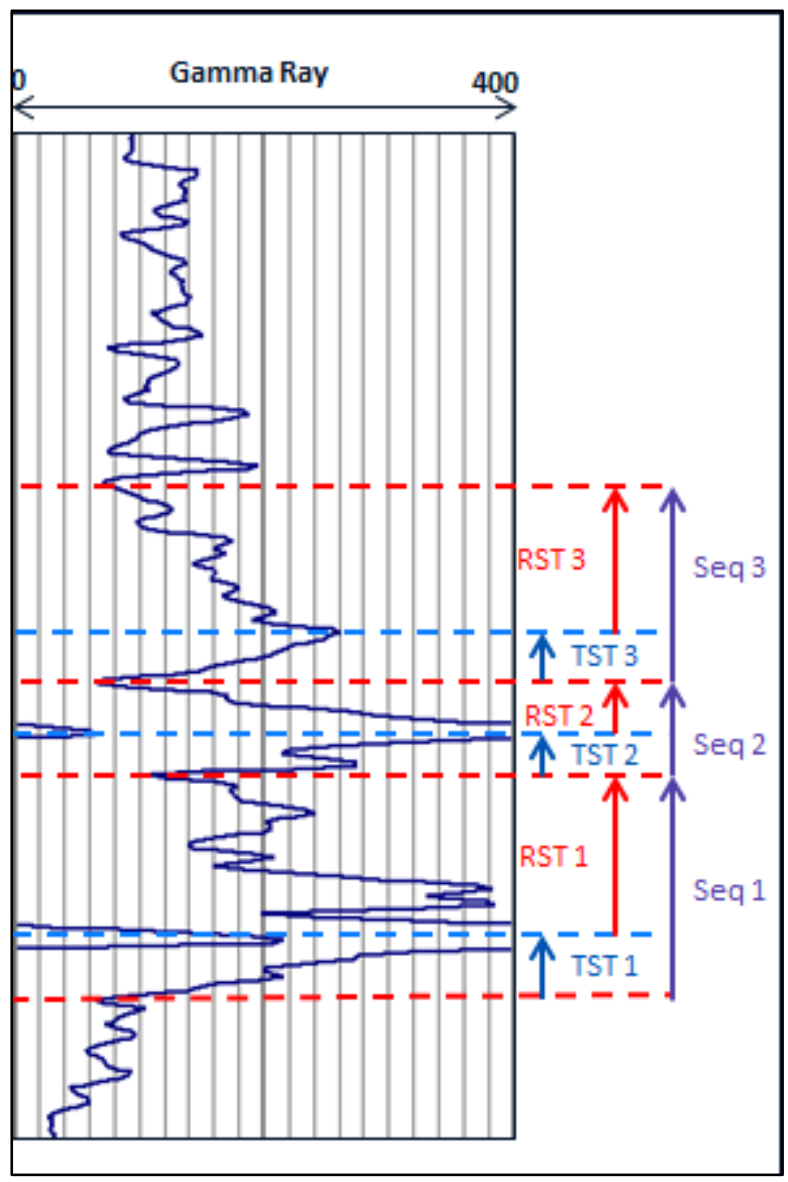

Figure 36. Type log showing various transgressive-regressive sequences (T-R Sequence \#s) represented by purple arrows. Also displayed are the various systems tracts, with the transgressive systems tracts (TST) represented by blue arrows and the regressive systems tracts (RST) represented by red arrows. The dashed red lines represent maximum regressive surfaces (MRS). The dashed blue lines represent maximum flooding surfaces (MFS). The solid red lines represent litho-formation boundaries. 


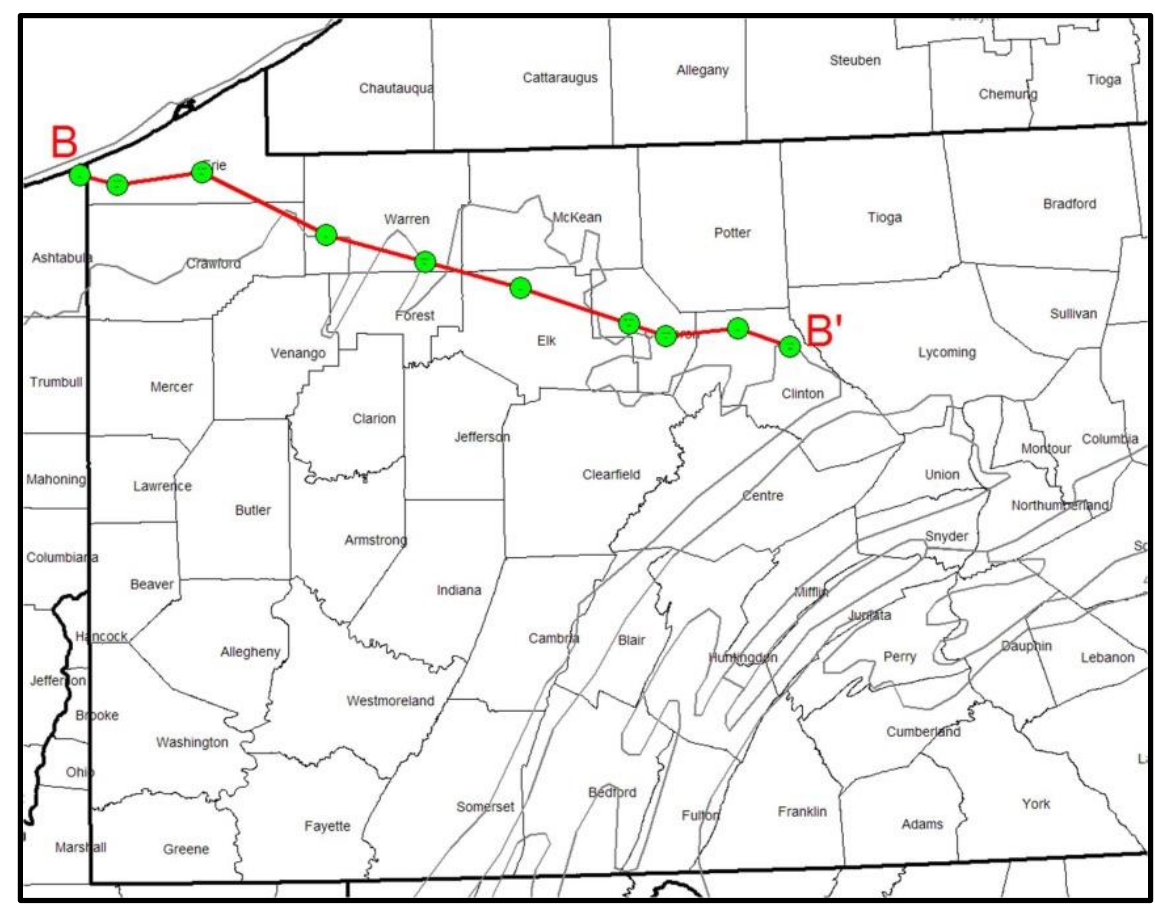

Figure 37. Location of sequence stratigraphic cross section (red line) and wells (green dots). 


\section{TRANSGRESSIVE-REGRESSIVE SEQUENCE 1}

Figure 39 is the isopach map of the first transgressive-regressive sequence in the Marcellus Shale. The depocenter of the formation strikes N45E with the thickest portion approximately 135 feet $(41.2 \mathrm{~m})$ thick near the study's eastern edge in Pennsylvania and New York. From this thick the sequence thins to less than 20 feet $(6.1 \mathrm{~m})$ in western Pennsylvania and southwestern New York. In West Virginia the thickest portion of the sequence is approximately 80 feet $(\mathrm{m})$ in north central West Virginia. The sequence thins to less than 10 feet in the southwestern portion of West Virginia. 


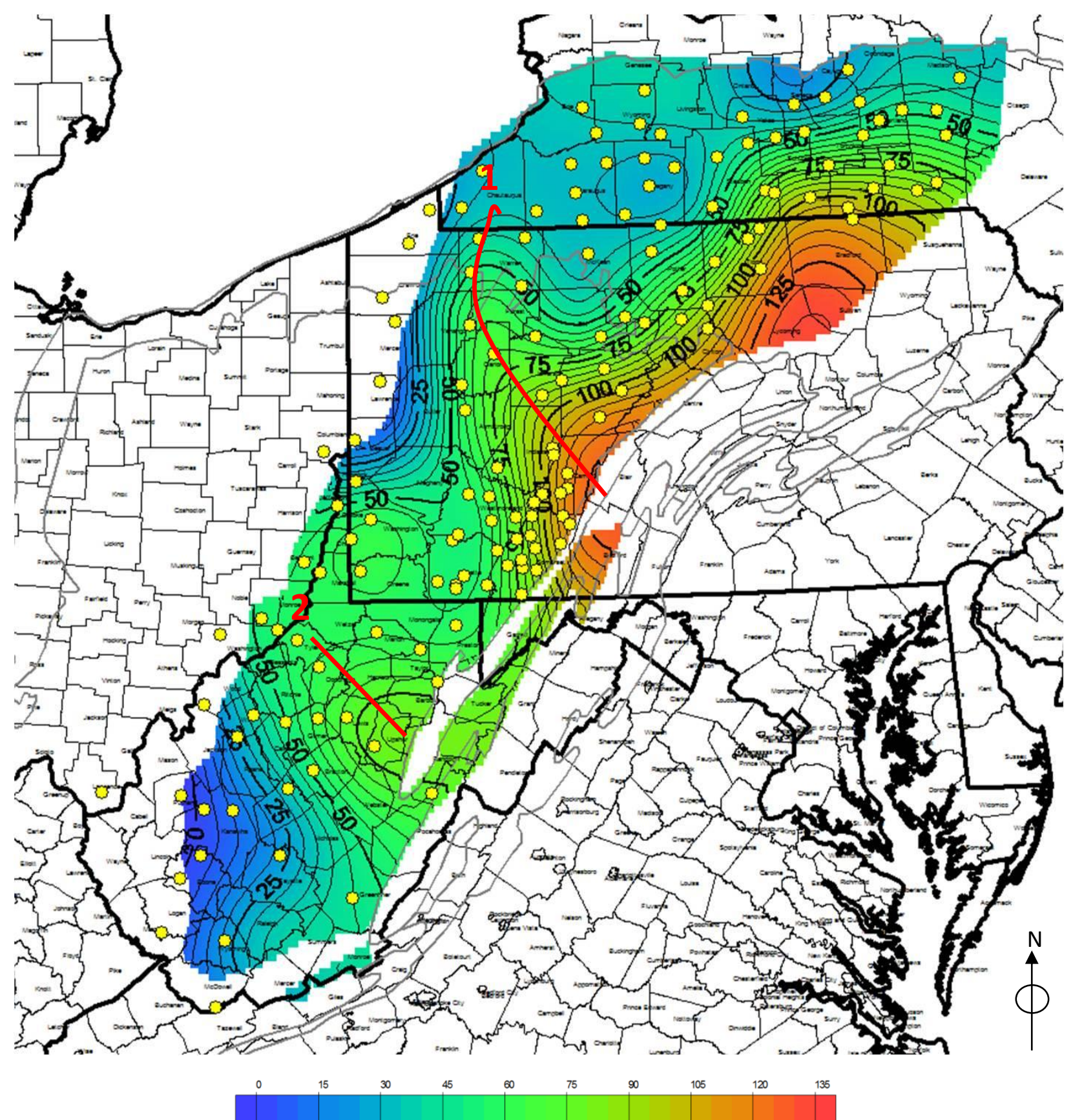

Figure 39. Isopach map of the first Transgressive Regressive Sequence. The red-solid lines represents cross strike features in the first sequence. 
Figure 40 is the isopach map generated for the first transgressive systems tract in the first sequence of the Marcellus Shale. The depocenter of the formation strikes $\mathrm{N} 45^{\circ} \mathrm{E}$ with the thickest portion approximately 55 feet $(16.8 \mathrm{~m})$ thick near the study's northeastern edge in Chemung County, NY and Bradford County, PA. From this thick the sequence thins to less than 10 feet $(3.1 \mathrm{~m})$ in southwestern New York and western Pennsylvania. In West Virginia, the thickest portion of the sequence is approximately 50 feet $(15.2 \mathrm{~m})$ in Upshur County West Virginia. The systems tract thins to less than 10 feet $(3.1 \mathrm{~m})$ to the south-central portion of West Virginia.

This sequence also displays several areas of thinning. The first area is a thinning crossstriking feature that occurs between the first two cross-strikes mentioned above. This thinning feature strikes southeast with a thickness of less than 10 feet $(3.1 \mathrm{~m})$. The next area of thinning occurs over the entirety of Clearfield County, and parts of Jefferson, and Indiana Counties in central PA with a thickness of less than 20 feet $(6.1 \mathrm{~m})$. The final area of thinning occurs in south central West Virginia, with the greatest thinning in Roane County, and parts of Kanawha, and Clay counties at less than 10 feet $(3.1 \mathrm{~m})$ thick. 


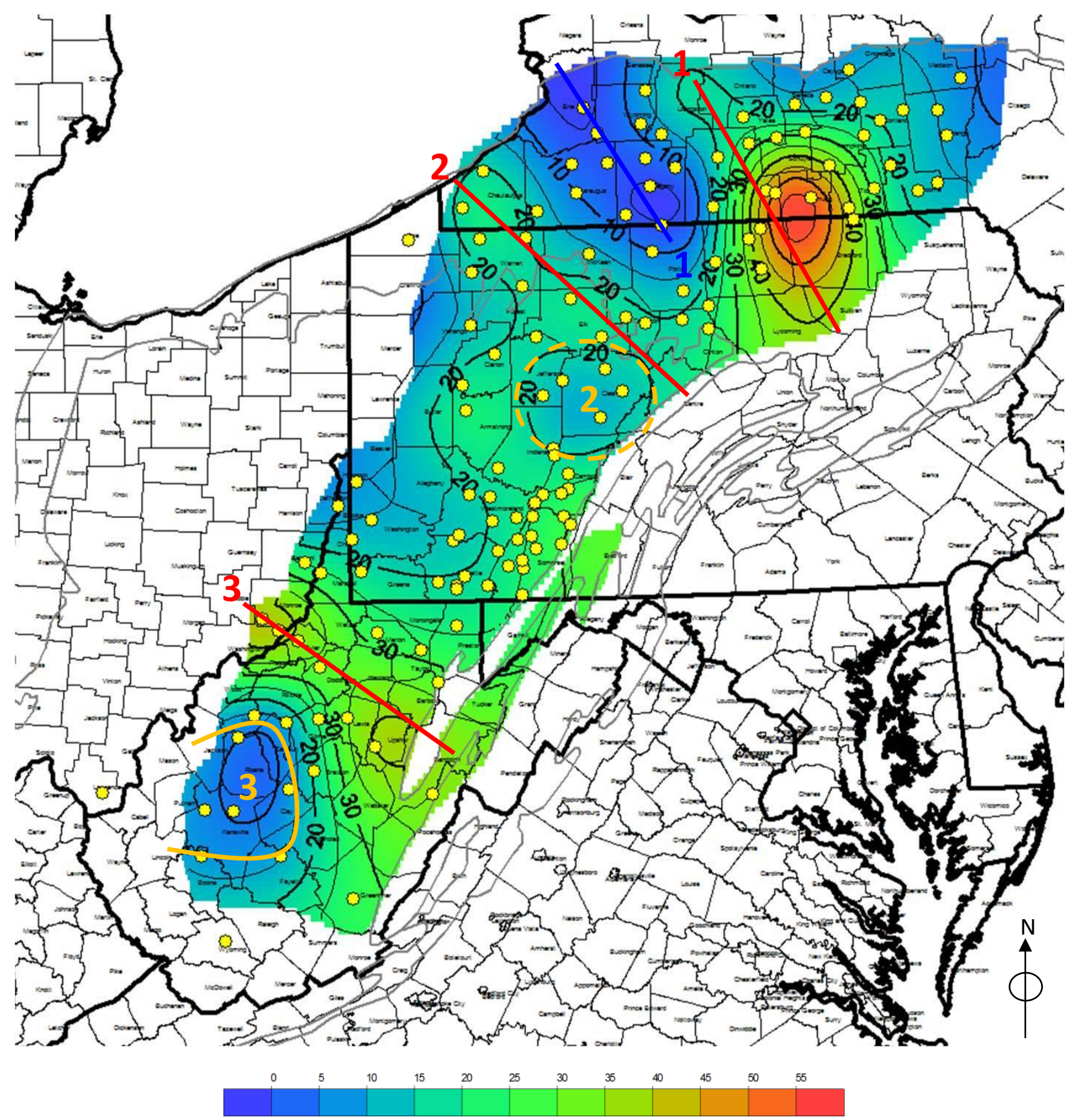

Figure 40 Isopach map of the first Transgressive Systems Tract. The red-solid lines represent cross strike features in the systems tracks. The orange-solid lines represent areas of thinning and the orange-dashed line represents an area of anomalous thinning. 
Figure 41 is the isopach map generated for the first regressive systems tract in the first sequence of the Marcellus Shale. The depocenter of the formation strikes $\mathrm{N} 45^{\circ} \mathrm{E}$ with the thickest portion approximately 110 feet $(33.5 \mathrm{~m})$ thick near the study's eastern edge in Pennsylvania. From this thick the sequence thins to less than 20 feet $(6.1 \mathrm{~m})$ in southwestern New York, and western Pennsylvania. In West Virginia, the thickest portion of the sequence is approximately 40 feet $(12.2 \mathrm{~m})$ in north central West Virginia. The systems tract thins to less than 10 feet $(3.1 \mathrm{~m})$ to the southwest in West Virginia. 

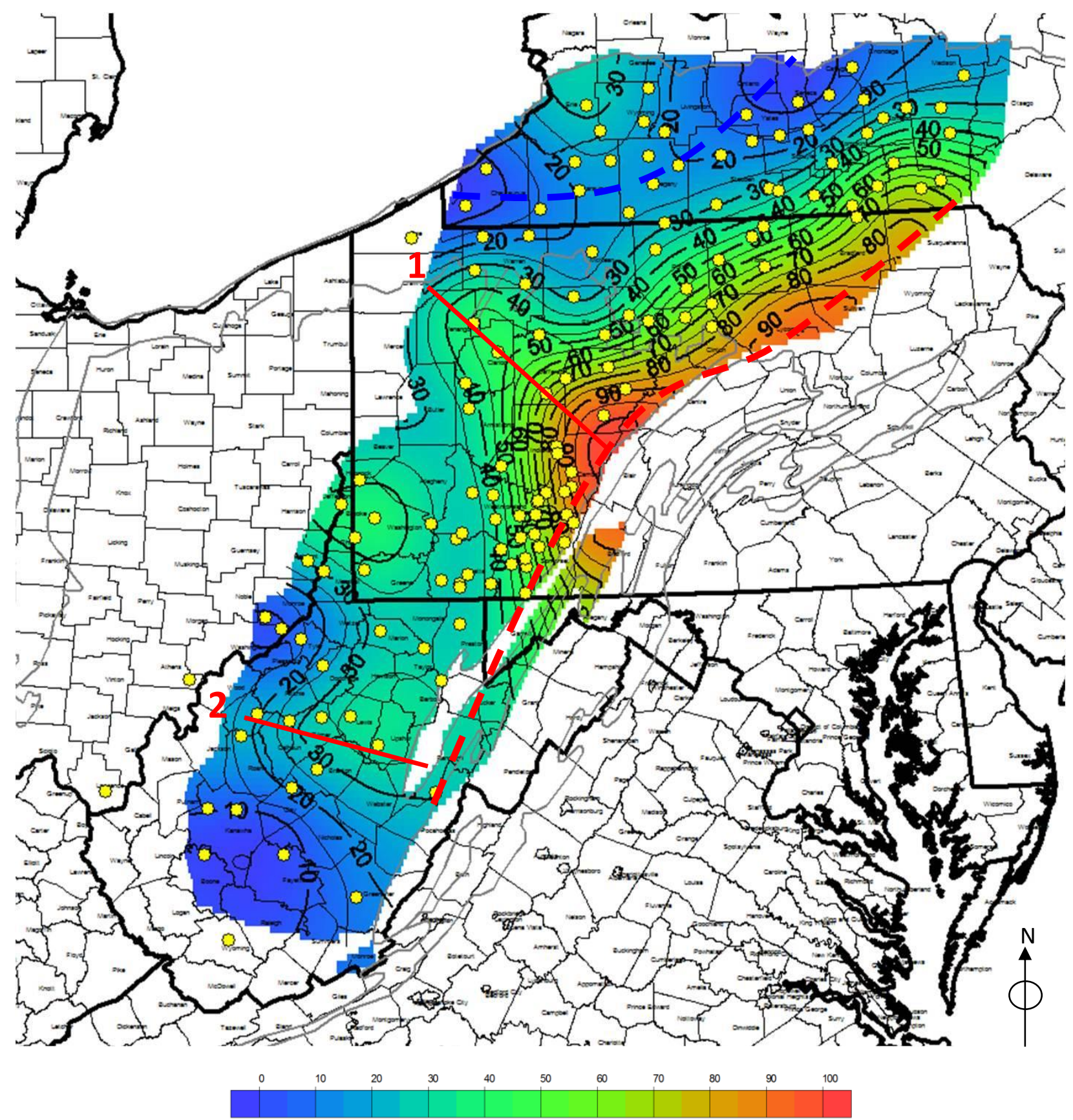

Figure 41. Isopach map of the first Regressive Systems Tract. The red-dashed line represents the main body of the systems tract. The red-solid lines represent cross strike features and the bluedashed line represents an area of thinning. 


\section{TRANSGRESSIVE REGRESSIVE SEQUENCE 2}

Figure 42 is the isopach map generated for the second transgressive-regressive sequence in the Marcellus Shale. The depocenter of the formation strikes west to east with the thickest portion approximately 100 feet $(30.1 \mathrm{~m})$ thick in south-central Pennsylvania and northern West Virginia. From this thick the sequence thins to less than 25feet $(7.6 \mathrm{~m})$ in southern New York and northern Pennsylvania. In West Virginia, the thickest portion of the sequence is approximately 80 feet $(24.4 \mathrm{~m})$ in northern West Virginia. The sequence thins to less than 25 feet $(7.6 \mathrm{~m})$ to the southern portion of the state.

This sequence displays two cross-strike features that appear to be lobe-shaped. The first cross-strike feature occurs in southwestern New York. The feature encompasses most of Chautauqua County, NY, and is over 60 feet $(18.3 \mathrm{~m})$ thick as it extends into Warren, Erie, Crawford and Venango Counties, PA, where it thins to less than 40 feet $(12.2 \mathrm{~m})$. The second feature occurs in southwestern Pennsylvania and strikes to the south into West Virginia. The depocenter of the feature is approximately 80 feet thick $(24.4 \mathrm{~m})$ and thins to less than 50 feet $(15.2 \mathrm{~m})$ as it extends into northern West Virginia.

In addition to the cross-strikes, the sequence has three areas of thinning. The first occurs in southwestern New York and extends south to central Pennsylvania. This feature thins to less than 25 feet $(7.6 \mathrm{~m})$ and appears to wrap around the first cross-strike feature mentioned above. The second area of thinning occurs in south central New York and thins to approximately less than 20 feet $(6.1 \mathrm{~m})$ thick. The final area of thinning occurs in southwestern West Virginia and reaches to the north east into central West Virginia. The feature thins to less than 25 feet (7.6 $\mathrm{m})$. 


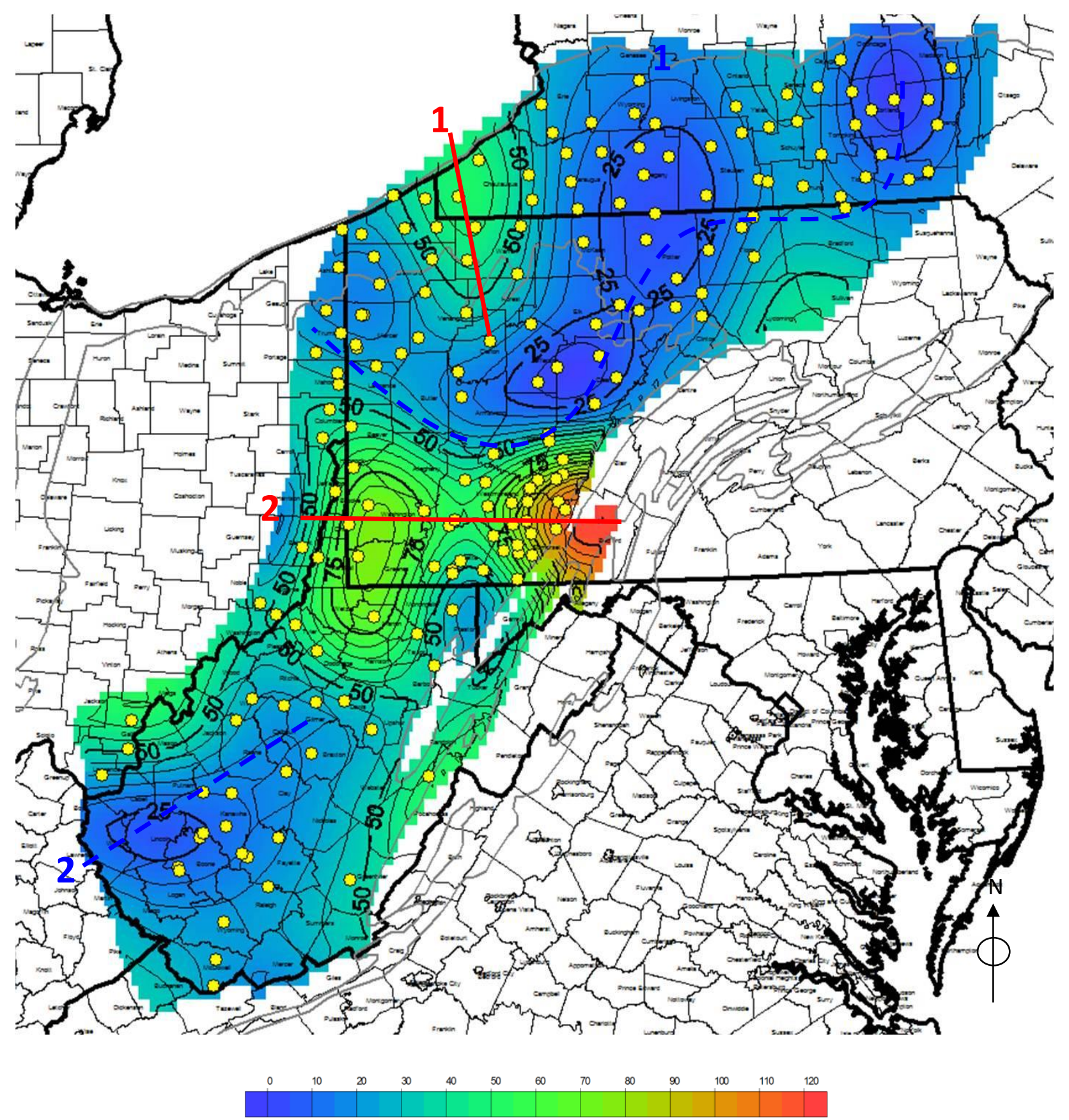

Figure 42 Isopach map of the second Transgressive Regressive Sequence. The red-solid lines represent cross strike features. The blue-dashed lines represent areas of thinning in the sequence. 
Figure 43 is the isopach map of the transgressive systems tract in the second sequence of the Marcellus Shale. The depocenter of the systems tract strikes $\mathrm{N} 45^{\circ} \mathrm{E}$ with the thickest portion approximately 30 feet $(9.1 \mathrm{~m})$ thick near the study's eastern edge in Pennsylvania. From this thick the sequence thins to less than 5 feet $(1.5 \mathrm{~m})$ in central to northern Pennsylvania, and New York. In west-central Pennsylvania there is an anomalous thickening. The maximum thickness of this area is 30 feet $(9.1 \mathrm{~m})$. 


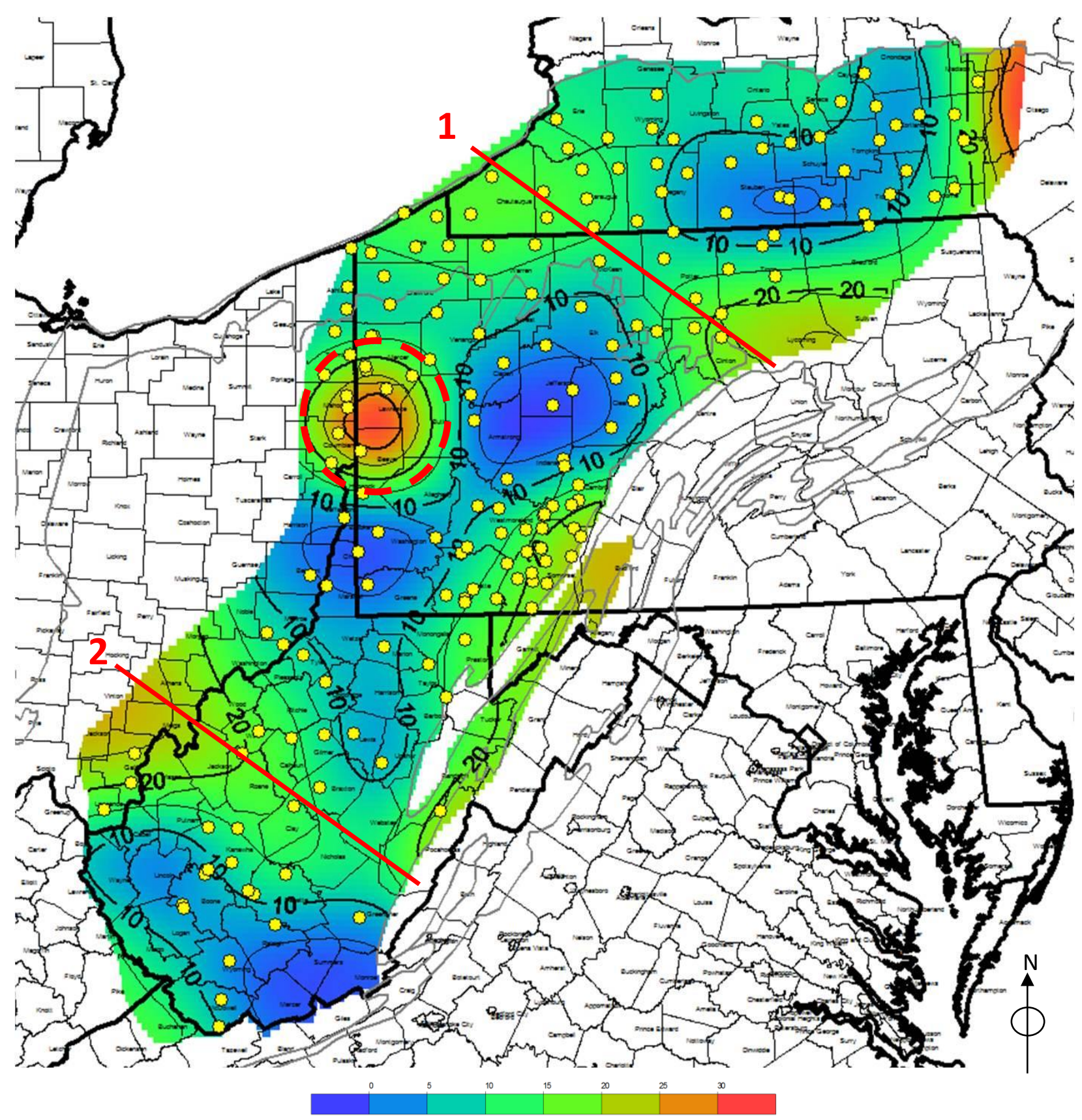

Figure 43 Isopach map of the second Transgressive Systems Tract. The red-solid lines represent cross strike features. The red-dashed line represents an area of anomalous thickening. 
Figure 44 is the isopach map of the regressive systems tract in the second sequence of the Marcellus Shale. The depocenter of the formation strikes west to east with the thickest portion approximately 95 feet $(30 \mathrm{~m})$ thick in south-central Pennsylvania and northern West Virginia. From this thick the sequence thins to less than 10 feet $(3.1 \mathrm{~m})$ in southern New York and northern Pennsylvania. In West Virginia, the thickest portion of the sequence is approximately 70 feet $(21.3 \mathrm{~m})$ in northern West Virginia. The systems tract thins to less than 10 feet $(3.1 \mathrm{~m})$ to the southern portion of West Virginia. 


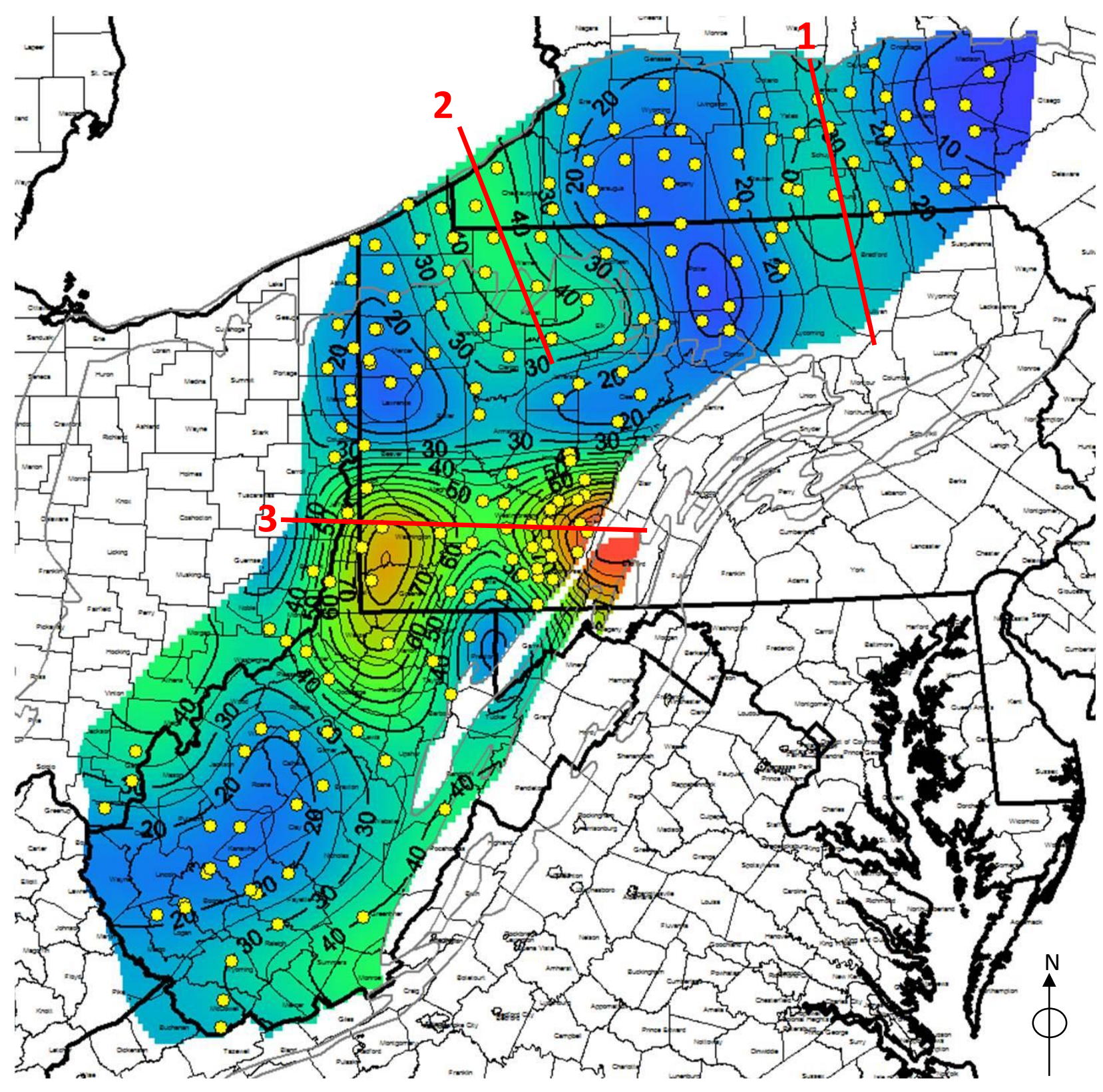

$\begin{array}{llllllllllll}0 & 10 & 20 & 30 & 40 & 50 & 60 & 70 & 80 & 90 & 100\end{array}$

Figure 44 Isopach map of the second Regressive Systems Tract. The red-solid lines represent cross strike features in the systems tract. 


\section{TRANSGRESSIVE REGRESSIVE SEQUENCE 3}

This sequence is present in the north and east portions of the study area but does not extend into the western area. The reason for this is that the log signatures used to define this Transgressive-Regressive Sequence lose character and undergo a facies change to undifferentiated shale as the sequence is traced to the west.

Figure 45 is the isopach map generated for the final transgressive-regressive sequence in the upper Marcellus Shale and lower Mahantango. The depocenter of the formation is thickest at approximately 80 feet $(24.4 \mathrm{~m})$ thick near the study's eastern edge in Pennsylvania. From this thick the sequence thins to less than 5 feet $(1.5 \mathrm{~m})$ in western New York and Pennsylvania. In West Virginia, the thickest portion of the sequence does not exceed 30 feet $(9.1 \mathrm{~m})$ in north eastern West Virginia. The shale thins to a feather's edge beyond the northeastern section of the state. 


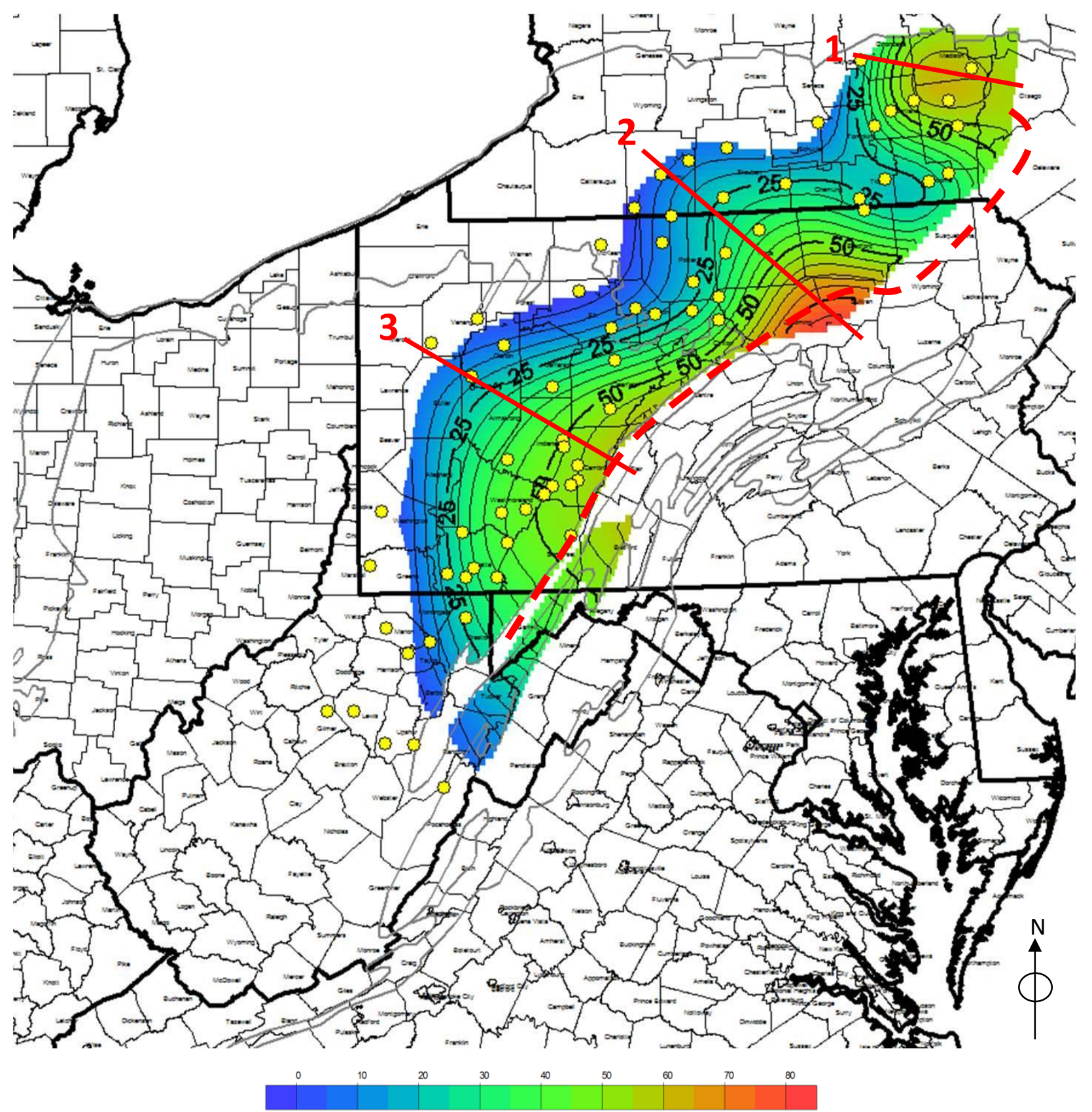

Figure 45 Isopach map of the third Transgressive Regressive Sequence. The red-dashed line represents the main body of the sequence. The red-solid lines represent cross strike features that occure in the sequence. 
Figure 46 is the isopach map of the transgressive systems tract in the third sequence of the Marcellus Shale. The depocenter of the formation strikes $\mathrm{N} 45^{\circ} \mathrm{E}$ with the thickest portion approximately 30 feet $(9.1 \mathrm{~m})$ thick near the study's eastern edge in New York. From this thick the sequence thins in western Pennsylvania and New York. In West Virginia, the thickest portion of the sequence is approximately 10 feet $(3.1 \mathrm{~m})$ in north eastern West Virginia, and is absent over the rest of the state. 


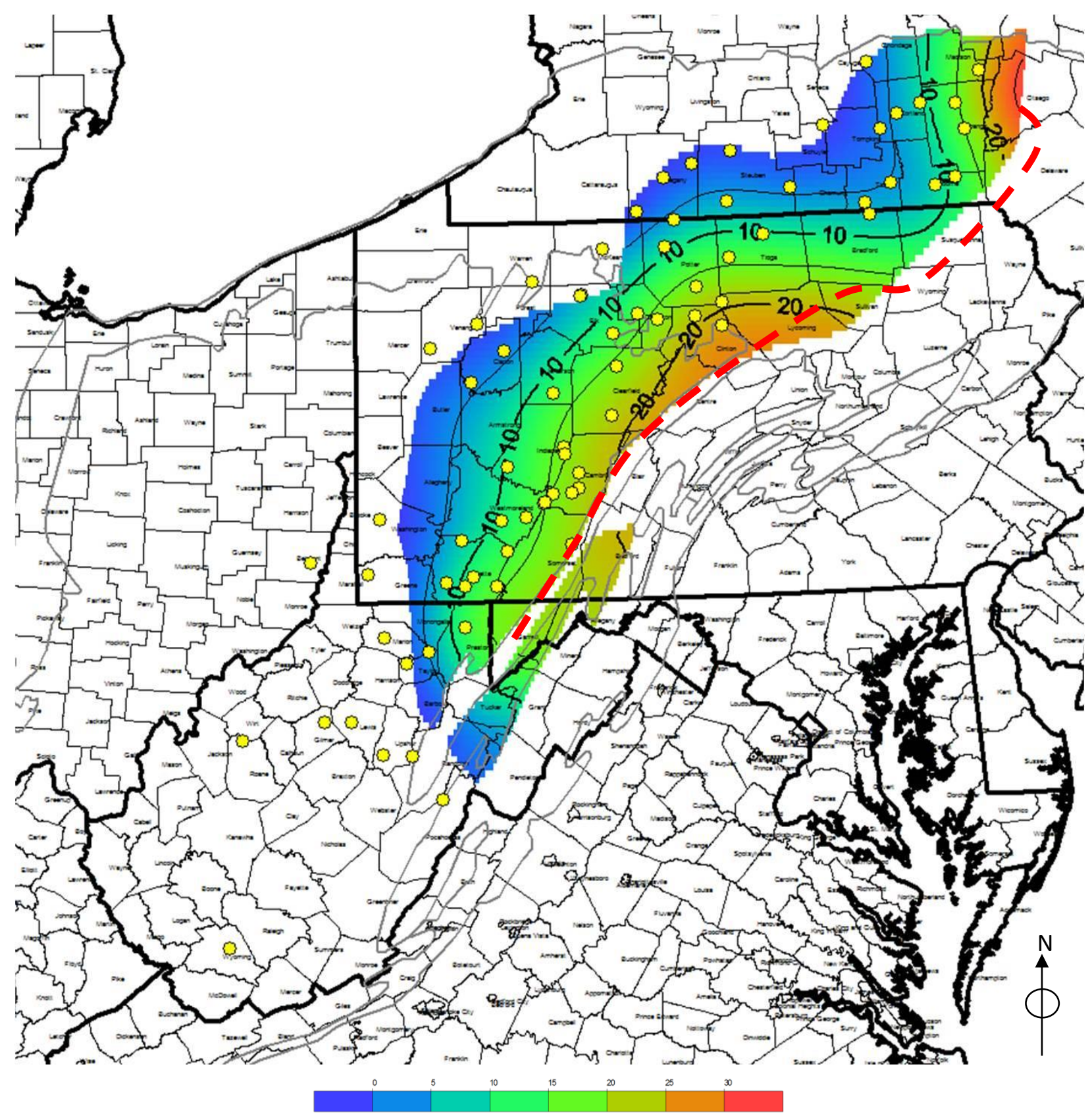

Figure 46 Isopach of the third Transgressive Systems Tract. The red-dashed line represents the main body of the systems tract. 
Figure 47 is the isopach map of the regressive systems tract in the third sequence of the Marcellus Shale. The depocenter of the formation strikes $\mathrm{N} 45^{\circ} \mathrm{E}$ with the thickest portion approximately 55 feet $(16.8 \mathrm{~m})$ thick near the study's eastern edge in Pennsylvania From this thick the sequence thins to a feather's edge in western Pennsylvania and New York. In West Virginia the thickest portion of the sequence does not exceed 20 feet $(6.1 \mathrm{~m})$ in north eastern West Virginia, and the systems tract is absent in the rest of the state. 


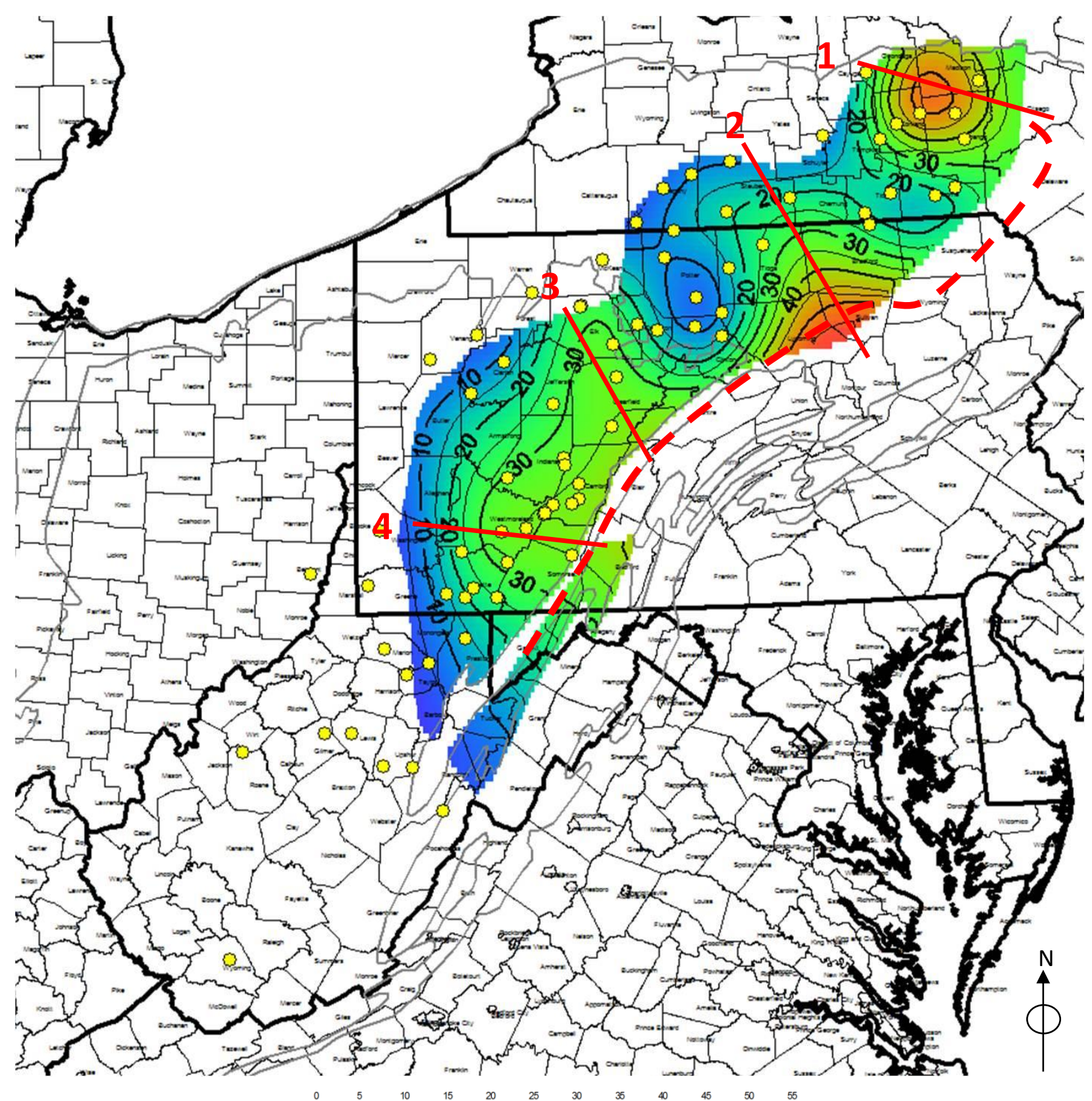

Figure 47 Isopach map of the third Regressive Systems Tract. The red-dashed line represents the main body of the systems tract. The red-solid lines represent cross strike features in the sequence. 


\section{DISCUSSION}

\section{SEDIMENTOLOGY, STRATIGRAPHY, AND DEPOSITIONAL SETTING}

The strike of the Marcellus Shale depositional basin is roughly N45 ${ }^{\circ}$ (Figure 2) and runs parallel to the Rome Trough in Pennsylvania; there is a slight westward shift in thickness, however caused by the Upper Cambrian basement faults as a result of reactivation during the Middle Devonian time (Ettensohn 2005, Engelder 2008). The faults caused a structural low in the basin which filled with additional sediments from the eastern source area during Marcellus deposition. In West Virginia the strike of the Marcellus depositional basin is shifted eastward from the trend of the Trough and closely follows the change in azimuth of the Upper Cambrian and Lower Ordovician faults as they turn southward in southwestern Pennsylvania (Figures 8 and 9).

In the northwest corner of the study area stratigraphic thinning of the Union Springs, Cherry Valley and Oatka Creek is attributed to a foreland bulge (Figures 11, 12 \& 13). During deposition, this region was a topographic high (Lash 2007, Lash 2008, Lash and Engelder 2009), and the foreland bulge led to nondeposition and possible erosion of sediments in the Union Springs member. In cross sections A-A', B-B', and C-C' (Figures 15, 16, and 17) this forebulge can be identified where the Oatka Creek thins and the Union Springs thins and pinches out. The strata thickens again on the westward side of the bulge (Fig. 17). The foreland bulge can be traced in a curvilinear pattern into southeastern West Virginia.

Figure 48 is a generalized Marcellus Shale paleogeographic map. The map was constructed by tracing a "cut-off" contour on various gamma-ray isopach maps. From this traced contour, a shaded polygon was generated. In order to show the main distribution of lithologic thicknesses, the following gamma ray isopachs were used with thickness cut-offs. The first 
isopach used to generate this map was the GR $<100$ API Map (Figure 26). A thickness cut-off of greater than 8' (average thickness of limestone and calcareous shale in the Marcellus Shale) was used to generate the limestone polygon. The second isopach map was the Gamma-Ray between 100 and 180 API (Nonorganic Shale) Isopach (Figure 27). A cut-off of 50' (average gray shale thickness) was used to generate the gray shale and organic-lean shale polygon. The final map used was the GR > 180 API (Figure 28) with a thickness cut-off of 50' (economically viable shale thickness) in order to represent organic-rich shale on the paleogeographic map. 


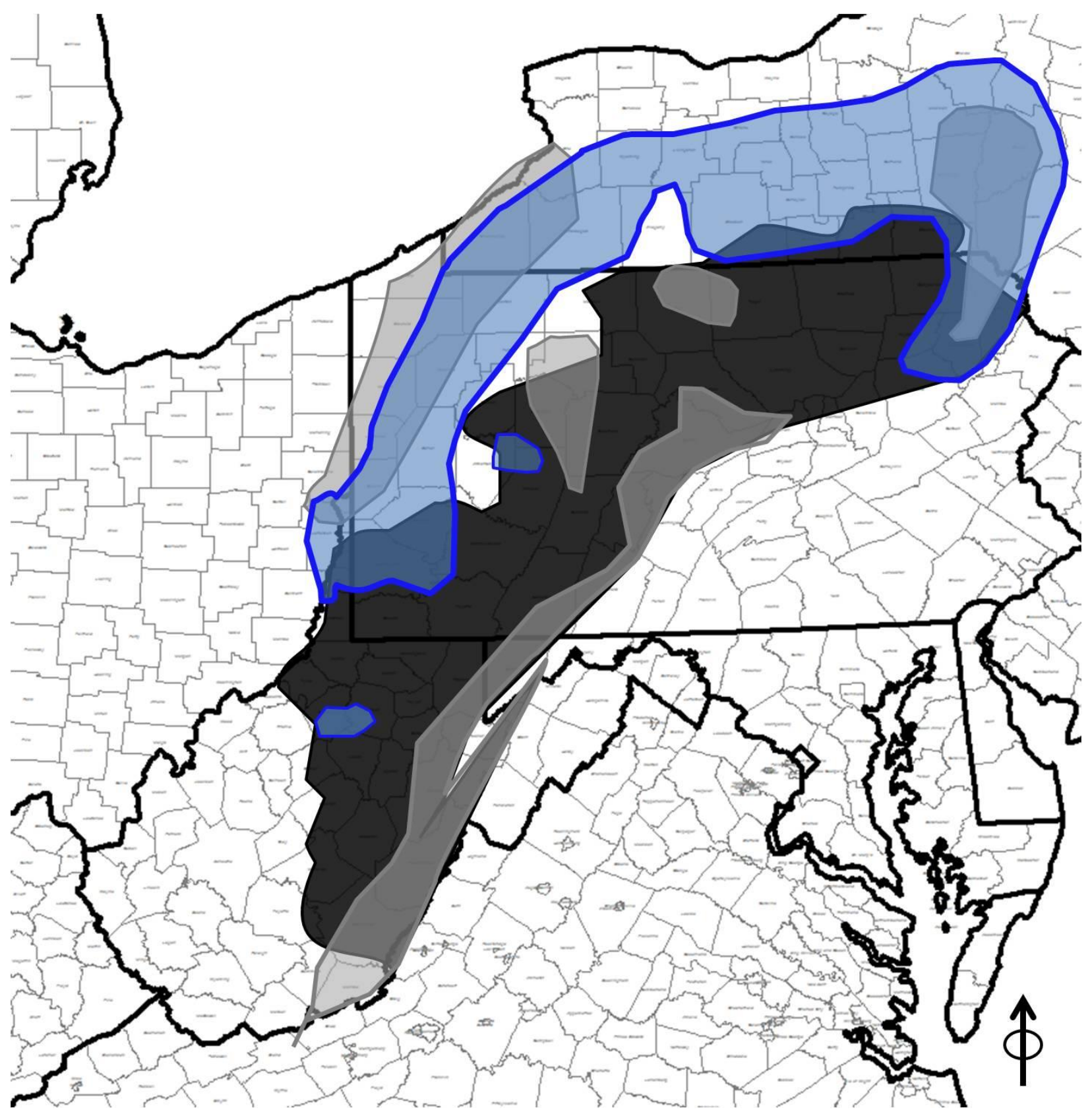

Figure 48. Paleogeographic Map indicating the distribution of three main lithologic types. The first is limestone and calcareous shale highlighted in blue. The second is gray shale to lean organic-rich shale and is highlighted in gray. The final lithologic type is organic-rich shale and is highlighted in black. 
The Marcellus Shale contains several limestone members shown by gamma-ray values less than 100 API. Some of these members are regionally contiguous enough to generate a gross thickness isopach map such as the Cherry Valley (Figure 38). However, the Purcell limestone that occurs stratigraphically within the Oatka Creek Member does not extend regionally throughout the basin and therefore cannot be accurately mapped with the data used in this thesis. The limestone members of the Marcellus were deposited during a time of low clastic input and mark times of maximum regression (Lash 2007, Lash and Engelder 2009). The distribution of limestone in Figure 26 indicates shallower water depth and the position of offshore carbonate shoals located in the western and northern portions of the study area. The GR $<100$ API reservoir map in (Figure 26) shows that limestone is thicker in northwestern Pennsylvania as a result of shallow water deposition over the foreland bulge. The increased limestone along the southern tier of New York was deposited along the shallow distal edge of the basin. It is important to note that there is a lack of limestone in West Virginia; this area may suggest greater depths that were unaffected by sea level fluctuation.

Thick limestone can be an obstacle or a benefit in the completion process of oil and natural gas extraction. Limestone has a higher fracture threshold and can act as a stress barrier in the stimulation process (Bruner and Smosna 2011). The underlying Onondaga and overlying Tully Limestone are sufficiently thick enough to effectively isolate the Marcellus from underlying formations. The only true fracture barriers as seen in microseismic data are the Tully and Onondaga both greater than 20-40 ft in most cases (personal experience -Range Resources 2014). The Cherry Valley and Purcell Limestone are generally very thin and are treated with typical stimulation flow rates and pressures. 
The distribution of gray, organic-lean shale (Figure 48) indicates a proximity to the eastern source area, oxic bottom waters, and water depth above thermocline (Alegeo and Schekler 1998, Werne et al. 2002, Ettensohn 2009, Wrightstone 2010, Walker-Milani 2011). The net thickness between 180 and 100 API map (Figure 27) shows that in addition to the limestone that occurs in this area, non-black shale also thickens in northwestern Pennsylvania due to the shallow water over the foreland bulge and may be indicative of the eastern flank of foreland bulge (Ettensohn 2005, Lash 2007, Lash and Engelder 2009). Deposition of non-black shale also occurs on the eastern portion of the study area due to close proximity to the source area.

The distribution of black, organic-rich shale (figure 48) indicates the relatively deep anoxic water below the thermocline west from the source area (Schwietering 1981, Prave et al 1996, Alegeo and Schekler 1998, Ettensohn 2009, Boyce 2010, Walker-Milani 2011). This distribution coincides with the orientation of the Rome Trough (Fig 9) in Pennsylvania and the Upper Cambrian basement faults in West Virginia, and suggests that basement faulting controlled distribution of Marcellus organic-rich rocks. 


\section{PETROLEUM ISOPACH MAPS}

The gamma-ray log is the most common well log, readily available, most consistent, and it provides continuous data down hole. Although gamma-ray values in excess of 300-400 API units are not common, values can be as great as 600 API units (Zagorski and Wrightstone 2012). However, most of the Marcellus falls within 200-300 API units (Engelder 2008).

One major purpose of this study is to correlate typical gamma-ray values to the organicrichness of shale, although admittedly gamma-ray measurements act only as a proxy for the total organic content in the rock. There are many other factors which can affect the gamma-ray response in any rock. Changes in ionic abundances such as $\mathrm{CO}_{3}$ and $\mathrm{PO}_{4}$ in Devonian sea water could have affected the solubility, sorption, and reduction of available uranium, and the gammaray reading is directly tied to uranium absorbed into the organic matter. The gamma-ray response can also depend upon the volcanic-ash content (higher levels of potassium $\mathrm{K}$ and thorium Th than found in clay minerals), the degree of illitization by basin fluids, and the total organic content in the sediment (absorbed uranium U). Furthermore, uranium in the organic matter depends on the carbonate content of the shale, the sedimentation rate, and the primary uranium content in seawater (Boyce 2010).

The most common gamma-ray cut-off value for black shale is 200 API units. This number is used by many authors and appears to generate fairly consistent maps of organic-rich intervals in the Marcellus Shale (Streib 1980, Zaengle 2008, Lash and Engelder 2009, Boyce 2010, Zagorski and Wrightstone 2012). Other authors use a gamma-ray cut-off of 230 API (Avery and Lewis no date, Cliff Minerals Inc. 1979, Hill et al. 2002, Myers 2008, Boyce 2010). This value generally indicates the very best, most organic-rich, black shale (Myers 2008). The 
Unconventional Gas Center (2009) used a much higher cut-off of 300 API. Hill et al. (2002)

noted that over $90 \%$ of black shale in the Marcellus has a gamma-ray value of less than 230 API units.

On the other hand, Schmoker (1981) found that Devonian Shale without any organic matter has a gamma-ray range of 125-175 API. Nuttal et al. (2005) determined that inorganic shale has a range of 150-200 API. Streib (1980) noted that black shale observed in core can have a gamma-ray value as low as 175-180 API units. These latter studies suggest that a minimum cut-off for organic-rich shale would be 175 API.

Some authors identify organic-rich rock by a gamma-ray value greater than that of gray undifferentiated shale +20 API units. The additional 20 API units reflect the organic material in the shale (Piotroski and Harper 1979, De Witt et al. 1993, Hill et al. 2002, Myers 2008, Martin et al. no date). Wrightstone (2009) used a gamma-ray cut-off of gray undifferentiated shale +60 API units.

The 180 API map in (Figure 28) represents the total thickness of what constitutes quality or economically viable shale, but not necessarily the highest yield reservoir of the Marcellus. Regionally the best portion of this map (thickness greater than $50^{\prime}$ ) trends $\mathrm{N} 45^{\circ} \mathrm{E}$ along the eastern portion of the study area. This map is tier 1 and includes marginal shale, viable shale and exceptional shale thicknesses. A thickness less than 50' may not contain enough pay for an economically viable well (Streib 1980, Schmoker 1981). The 200 API Isopach map (Figure 29) represents the cut-off of greatest interest for the Marcellus because the total organic carbon may be $12 \%$ or higher (Streib 1980, Nuttal et al 2005, Zaengle 2008, Wrightstone 2009, Boyce 2010). The highest yield portion of this map trends reflects the trend in the 180 API map, along the 
eastern portion of the study area. This map is tier 2 and contains viable shale plus exceptional shale. The 250 API Isopach map, (Figure 30) shows areas of highest expected yield if all other variables are similar, such as thermal maturity and kerogen type. This maps contains several small hotspots (net thickness greater than 50 feet) along the central portion of the study area. The first occurs in central West Virginia, the second occurs in north-central Pennsylvania, and the third occurs in northeastern PA and into south-central New York. This is a tier 3 map and contains only exceptional shale. This map shows areas with exceptionally higher organic carbon content but the total area with a section greater than $50 \mathrm{ft}(15.2 \mathrm{~m})$ thick is very small. The 300 API Isopach map (Figure 31) has a thickness that is too thin and aerially restrictive to be of much use in exploration.

$$
\begin{aligned}
& \text { Map GR >250 API }=\text { Tier } 3 \text {, highest expected yield } \\
& \text { Map GR>200 API }=\text { Tier } 2 \text { plus tier } 3 \\
& \text { Map GR >180 API }=\text { Tier } 1 \text { plus Tier } 2 \text { plus Tier } 3
\end{aligned}
$$

Just like the gamma-ray, bulk-density measurements act only as a proxy for the total organic content in the rock (Fig. 49, \& 50) (Laughrey 2009, Cluff 2009, Boyce 2010). There are many other factors which can affect the bulk-density response in any rock. The condition of the borehole may affect the reading of the bulk-density log because in order to read the rock, the tool must have direct contact to the surface of the rock that is, no washout of the wellbore. If there is gas in place within the formation, this may cause the tool to read lower. Another factor that may influence the reading of the bulk-density tool is the presence of fluids in the formation, and the shale's mineral content such as pyrite, anhydrite and dolomite (Boyce 2010). A bulk-density of $2.55-2.40$ correlates to a TOC of $\sim 3 \%$. A bulk-density of $2.4-2.35$ correlates to TOC ranging from $5-8 \%$ and finally bulk-density of less than 2.35 correlates to TOC of 6-10\% (Cliff Minerals 
Inc. 1979, Gottshling 2007, Engelder 2008, Smith and Leone 2009, Boyce 2010). This low bulkdensity reading is thought to represent the best, most organic-rich portion of the shale. Boyce (2010) used a cut-off value of $2.55 \mathrm{gm} / \mathrm{cc}$ to represent the less-organic portion of the shale, but still with enough TOC to be of economic viability. 


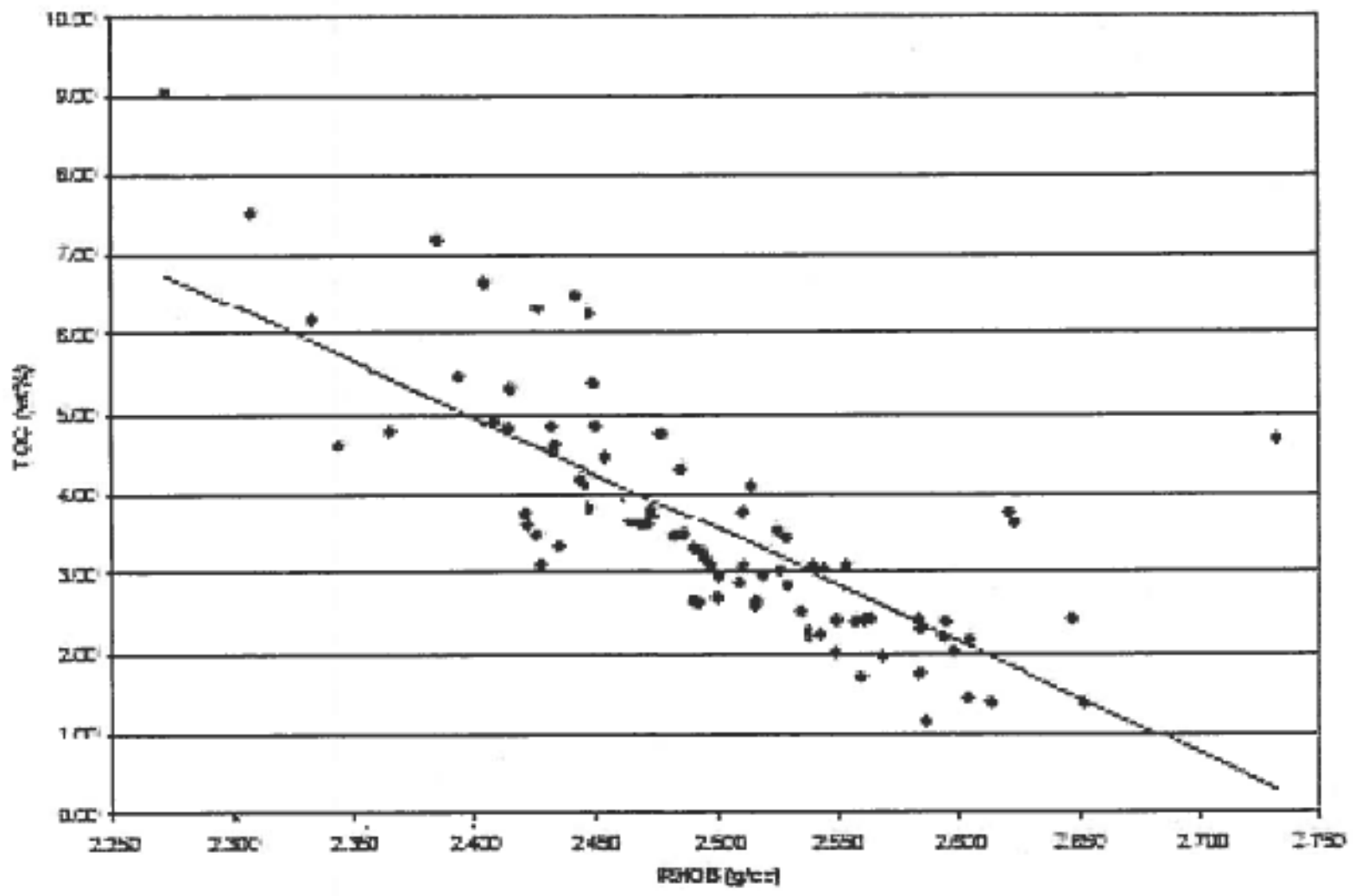

Figure 49. Cross plot of RhoB vs TOC (From Laughrey 2009) 


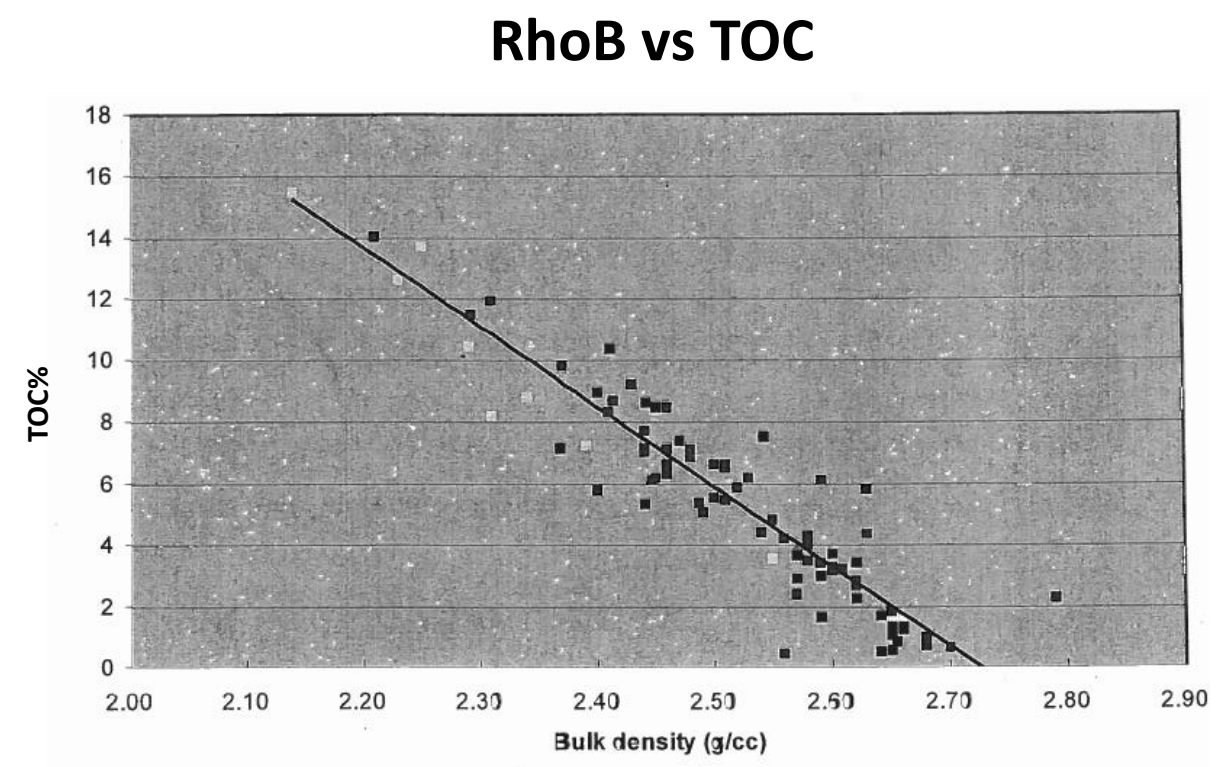

Figure 50. Cross Plot of RhoB vs TOC\% (From Cluff 2009) 
The 2.55 bulk-density net thickness map in (Figure 33) is a tier 1 map and includes marginal shale, viable shale and exceptional shale thicknesses. The thickest portion of this map occurs in northern West Virginia, southeastern Ohio, and southwestern Pennsylvania. Another exceptional area of thickness occurs in central Pennsylvania, and another occurs in south-central New York. The majority of the Marcellus thickness in this map is westward of the Rome Trough. This map may represent the best section for exploration within the Marcellus Shale because the net thickness is the largest within the bulk-density maps. The 2.4 Bulk-density net thickness map in (Figure 34) is a tier 2 map and includes viable shale and exceptional shale thicknesses. The thickest portion of this map occurs in northern West Virginia and southeastern Ohio, and another hotspot in central Pennsylvania. The map displays a similar trend as the 2.55 Bulk-density map but with only half the thickness. The thickest portions of the 2.35 bulk-density Net Thickness map (Figure 35) may represents tier 3 or the highest expected yield if maturity and kerogen type is similar. The thickest portions of this map overlap the thickest portions of the 2.4 Bulk-density net thickness map in northern West Virginia and southeastern Ohio, and another in central Pennsylvania. This map has the thinnest section of all the bulk-density net thickness maps.

Map RhoB $<2.35 \mathrm{~g} / \mathrm{cc}=$ Tier 3, highest expected yield Map RhoB $<2.4 \mathrm{~g} / \mathrm{cc}=$ Tier 2 plus tier 3 Map RhoB<2.55 g/cc = Tier 1 plus Tier 2 plus Tier 3

\section{COMPARISON OF GAMMA-RAY AND BULK-DENSITY ISOPACH MAPS}

The two reservoir thickness maps that most closely correlate are the 2.55 Bulk-density net thickness map and the 180 API isopach map. A large portion of each map overlaps. Using a cross plot (Figure 51) the author has identified a linear trend for the comparison of bulk-density 
less than $2.55 \mathrm{~g} / \mathrm{cc}$ and 180 API values. As the bulk-density decreases and the gamma ray increases to the east in the net thickness maps (Figures 28, 29, 30, and 31), the main bodies of the maps separate. One explanation is clastic content in thicker areas of the Marcellus Shale. Increased clastic content will raise the bulk-density. In the west the Marcellus is thinner with a lower clastic content and thus displays a higher bulk-density cutoff thickness. 


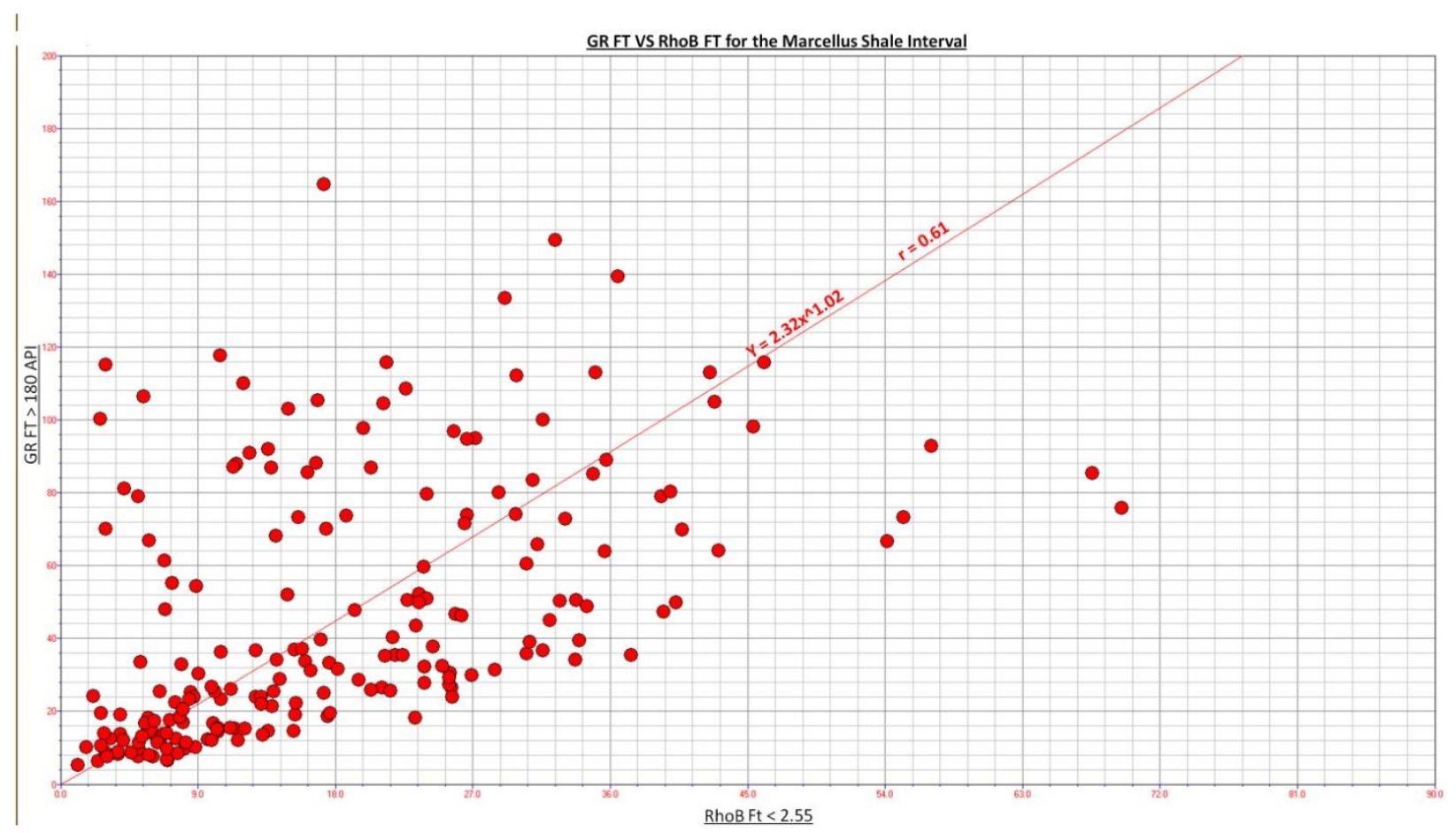

Figure 51. Cross plot with bulk-density less than $2.55 \mathrm{~g} / \mathrm{cc}$ plotted on the $\mathrm{x}$-axis and gamma ray greater than 180 API plotted on the y-axis. The linear regression value is 0.61 for this cross plot. 
Figure 31 is a map of the average gamma-ray value (API) over the Marcellus Shale gross thickness interval. The highest average API values display a trend similar to the trend in the Bulk-density cutoff reservoir maps. The gamma-ray net thickness maps (Figures 28-31) are shifted eastward due to the general thickening trend of the Marcellus Shale along with higher clastic content. The increased clastic content between quality reservoir zones may separate rock into multiple reservoirs instead of one combined reservoir. If the reservoir is separated, the thickest portion of these maps may not be the most economically viable pay. The average gamma-ray map shows the area of the Marcellus where clastic input has not reduced the quality of the reservoir. Higher average gamma-ray values predict a better reservoir yield. This map overlaid with the bulk-density net pay maps (Figures 33, 34, and 35) show that the best area for reservoir quality may lay along the western side of the study area. The gamma ray net thickness maps can be used to determine areas that the reservoir quality and thickness is enough to be feasible for horizontal drilling and completions.

\section{SEQUENCE STRATIGRAPHY}

A sequence stratigraphic model using the transgressive - regressive model of sedimentation (Catuneanu 2006, Embry 2009) was applied to the Marcellus in this study. These maps were generated using the gamma-ray peaks to represent maximum flooding surfaces and gamma-ray troughs to represent maximum regressive surfaces. According to the T-R model of sequence stratigraphy, a sequence begins at the first maximum regressive surface and extends upward past the maximum flooding surface to the next maximum regressive surface. Each surface was correlated across the study area, and isopach maps showing the thickness of each sequence and systems tract were generated (Catuneanu 2006). Three maps were generated representing each of the three transgressive-regressive sequences in the Marcellus. The first two 
sequences correlate to the lower Marcellus, Union Springs and Cherry Valley Members. The third sequence correlates to the upper Marcellus, Oatka Creek Member - Lower Mahantango. In addition to the full sequences, each was divided into systems tract maps representing the transgressive and regressive systems tracts. Because the sequence boundaries are approximate time lines, the sequence maps in Figure 39 show 3 time slices during Marcellus deposition (Embry 2002, Catuneanu 2006, and Lash 2010.)

The first transgressive systems tract (Figure 40) represents a sediment starved, condensed section of fining-upward, organic-rich facies (Figure 36) deposited during a period of rising relative sea-level (Embry 2002, Catuneanu 2006, Lash 2010). The flooding event was apparently rapid as indicated by the sharp shift in the gamma-ray (Figure 36) log above the shallow-water carbonates of the Onondaga Limestone. The regressive systems tract in Figure 41 represents a clastic dominated, shallow-marine, prograding facies where the strata comprise a coarsening-upward succession on the gamma-ray log (Figure 36) (Embry 2002, Catuneanu 2006). The thickness of this systems tract indicates that the clastic lobe of progradation was centered in central Pennsylvania and thinned to the north, west, and south.

The second T-R sequence map of the Marcellus (Figure 42) represents a time slice during the middle of the Marcellus Shale deposition. This sequence is much thinner than the transgressive-regressive sequence 1 . This could indicate that there was less total time in which this sequence was deposited. It could also indicate that there was less basin subsidence at which point the sequence may have had less accommodation space than the first sequence (Embry 2002, Catuneanu 2006, Lash 2010). This second sequence also displays a much less uniform geometry than the sequence 1 wedge-shape. The greatest thickness of the basin is much thicker in the central region than the northern and southern ends, which could indicate that the main 
source of the clastic material relocated to a central position in the eastern hinterlands due to delta avulsion and switching or shifting tectonic uplift. The second transgressive systems tract (Figure 43) represents yet another condensed section and a flooding event in the deposition of the Marcellus (Embry 2002, Catuneanu 2006, Lash 2010). The second regressive systems tract (Figure 44) represents a prograding, clastic-dominated facies capped by a carbonate-dominated limestone (Cherry Valley). The clastic lobe is smaller in area than the RST 1 lobe with a much less uniform geometry. Again the cause may be decreased clastic input and the relocation of the source area within the hinterlands (Embry 2002, Catuneanu 2006, Lash 2010).

The third sequence in Figure 45 in southwestern New York, western Pennsylvania and the majority of West Virginia becomes undifferentiated with the Mahantango. This indicates that during the deposition of this sequence, terrigenous sediment did not prograde as far to the west (Embry 2002, Catuneanu 2006, Lash 2010). It is possible that sediment starvation and basin deepening were occurring during this sequence, limiting the sediment supply to the north eastern portion of the basin. The third transgressive systems tract in Figure 46 represents a condensed section of fining-upward facies (Figure 36) (Embry 2002, Catuneanu 2006, Lash 2010). The body of this systems tract has a much more uniform geometry than the lower TST. This could represent a gradual rise in sea level leading to a more uniform wedge-like deposition of sediments. The third regressive systems tract (Figure 47) in the final Marcellus T-R sequence represents a time where the clastic lobe overstepped into eastern Pennsylvania due to a regression of the shoreline (Embry 2002, Catuneanu 2006, Lash 2010). Once more this could have been caused by a deep basin starved of sediment. The top of this systems tract correlates with the Stafford Limestone. 
In all of the maps the regressive systems track is much thicker than the transgressive systems tract. A prograding shoreline introduced a greater volume of clastic sediment into the basin during times of sea level fall. Higher sedimentation rates deposited a thicker section. The thinner section in the transgressive systems tract maps is indicative of increasing sediment accommodation space (faster than the rate of sedimentation) leading to a condensed section of organic-rich sediments (Catuneanu 2006, Lash 2010). The transgressive systems tracts represent the hot-organic sections of the Marcellus and correlate with the gamma-ray net pay maps. These systems tracts are regionally widespread enough for detailed mapping, and may prove valuable for geosteering targeting purposes as the best quality reservoir is contained within. 


\section{CONCLUSIONS}

The following conclusions were obtained through this study.

- Thickness of the Marcellus in NW PA and SE NY can be attributed to the effect of the central depocenter NE-SW through the study area, and the foreland bulge which runs parallel with the strike of the basin from PA into southern WV. Thickening of the Marcellus in the eastern panhandle of WV could be an indication of a sub-basin adjacent to the eastern source area.

- The Marcellus net thickness map with a gamma-ray below 100 API represents limestone. This thicker area overlaps the foreland bulge and is interpreted as a topographic high on the sea floor.

- The Marcellus net thickness map with a gamma-ray between 100 and 180 API can be used to determine the amount of "non-pay" shale (calcareous and gray) within the Marcellus. Area of thicker calcareous and gray shale overlaps the foreland bulge in western PA and also trends parallel to the basin depocenter in the eastern portion of the study area.

- The gamma-ray net thickness maps with gamma-ray greater than 180 API, 200 API, 250 API, and greater than 300 API show potential reservoir quality based on gamma-ray value. The best gamma-ray net pay map to use for oil and gas exploration is the $180 \mathrm{Net}$ Thickness API map because it shows the thickest and most regionally widespread distribution of viable pay. It should be noted, however, that these maps do not show if pay zone is interbedded with gray shale and/or limestone, which would be detrimental to the quality of the reservoir. 
- The map of average gamma-ray API value over the gross thickness of the Marcellus Shale is a better reservoir quality. Taking the average gamma-ray value over the interval factors both the "non-pay" and "pay" gamma-ray values. A high quality net thickness in conjunction with thin non-pay zones raises the average gamma-ray. Therefore high average gamma-ray value on the map shows the best quality reservoir.

- The bulk-density net thickness maps show organic-richness within the reservoir. The bulk-density net thickness less than $2.55 \mathrm{~g} / \mathrm{cc}$ show a trend farther west than that of the gamma-ray net thickness maps. This shift is due to the thickness of the Marcellus Shale. In areas where the shale is thinner there are less calcareous and gray shale intervals which increase the density of the rock. The effect of the foreland bulge can also be seen in the density net thickness maps in NW PA and SW WV by a thinner net thickness on the maps or higher density of the rock section.

- The best maps for oil and gas exploration are the bulk-density cut-off maps used in conjunction with the Average Gamma-Ray API Map. The overlap in the "hotspots" of these maps show promise for gas exploration because these areas will have the best reservoir quality and highest pay thickness.

- The transgressive systems tracts correlate to the most organic-rich sections within the Marcellus. They are regionally extensive, so that they may be mapped regionally and used in conjunction with the various net pay maps and average gamma-ray map to target the most organic-rich sections of the Marcellus.

- The regressive systems tracts correlate with limestone intervals and the most clastic-rich sections within the Marcellus. Where the regressive systems tracts are very thick, there is are more interbeds of non-pay rock between the organic-rich rocks within the Marcellus. 
These maps correlate with the thin sections in the net-pay and average gamma-ray maps in the eastern portion of the study area. 


\section{REFERENCES}

Algeo, T., and S. Scheckler, 1998, Terrestrial-marine teleconnections in the Devonian; links between the evolution of land plants, weathering processes, and marine anoxic events: Philosophical Transactions - Royal Society of London. Biological Sciences, v. 353, p. 113-130.

Avary, K.L., and Lewis, J.E., no date, New interest in cores taken thirty years ago: the Devonian Marcellus Shale in northern West Virginia: http://www.papgrocks.org/avary_pp.pdf, accessed December 2010.

Bank 2009, T., Malizia, T., and Giese, R., 2009 Geochemistry of Organic-rich Devonian Shales: 2009 Portland GSA Annual Meeting, Oct, 2009, Paper No. 168-7

Boyce, M., 2009, Subsurface stratigraphy and petrophysical analysis of the Middle Devonian interval of central Appalachian basin; West Virginia and southwest Pennsylvania: Pittsburgh Association of Petroleum Geologist, July, 2010, 40 p.

Boswell, R., 1996, Play USs: Upper Devonian black shales, in Roen, J.B., and Walker, B.J., eds., The atlas of major Appalachian gas plays: West Virginia Geological and Economic Survey Publication V-25, p. 93-99.

Bruner, K.R., and Smosna, R., 2011, A Comparative Study of the Mississippian Barnett Shale, Fort Worth Basin, and Devonian Marcellus Shale, Appalachian Basin: The Energy Lab DOE/NETL-2011/1478

Catuneanu, O., 2006. Principles of sequence stratigraphy: Elsevier BV.

Cluff, B. 2009, Shale Gas: Opportunities and Challenges for Independents or, What's in it for Me?: SIPES \#1832

Dennison, J.M., and Hasson, K.O., 1976, Stratigraphic cross section of Hamilton Group (Devonian) and adjacent strata along south border of Pennsylvania: American Association Petroleum Geologists Bulletin, v. 60, p. 278-298.

Dennison, J.M., and Textoris, D.A., 1970, Devonian Tioga Tuff in Northeastern united States: Bulletin of Volcanology, v. 34. p. 289-294.

De Witt, W., Roen, J.B., Wallace, L.G., 1993, Stratigraphy of Devonian Black Shales and Associated Rocks in the Appalachian Basin, in Petroleum Geology of the Devonian and Mississippian Black Shale of Eastern North America: USGS Bulletin 1909, p. B1-B57.

Embry, A.F., 2002. Transgressive-regressive (T-) sequence stratigraphy. In Sequence Stratigraphic Models for Exploration and Production: Evolving Methodology, Emerging Models and Application Histories (J.M. 
Armentrout and N. C. Rosen, Eds.), pp. 151-172. $22^{\text {nd }}$ Annual Gulf Coast Section SEPM Foundation, Bob F. Perkins Research Conference, Conference Proceedings.

Engelder, T., 2008, Structural Geology of the Marcellus and Other Devonian Gas Shales: Pittsburgh Association of Petroleum Geologists Field Trip, Sept. 12-13 2008.

Ettensohn, F.R., 1985, The Catskill Delta complex and the Acadian orogeny, in Woodrow, D.L., and Sevon, W.D., eds., The Catskill Delta: Geological Society America Special paper 201, p. 39-49.

Ettensohn, F.R., 1994, Tectonic controls on formation and cyclicity of major Appalachian unconformities and associated stratigraphic sequences, in Dennison, J.M., and Ettensohn, F.R., eds., Tectonic and eustatic controls on sedimentary cycles: SEPM Concepts in Sedimentology and Paleontology \#4, p. 217-242.

Ettensohn, F.R., 2005, The Sedimentary Record of Foreland Basin, Tectophase Cycles: Examples from the Appalachian Basin, USA: Cyclic Development of Sedimentary Basins, p. 137-172.

Ettensohn, F.R., 2008, Tectonism, Estimated Water Depths, and the Accumulation of Organic Matter in the Devonian-Mississippian Black Shales of the Northern Appalachian Basin: Search and Discovery, http://www.searchanddiscovery.com/abstracts/html/2008/eastern-pittsburgh/abstracts/ettensohn, accessed December 2010.

Flaherty, K.J., 1996, Fractured Middle Devonian Huntersville Chert and Lower Devonian Oriskany Sandstone: Upper Devonian black shales, in Roen, J.B., and Walker, B.J., eds., The atlas of major Appalachian gas plays: West Virginia Geological and Economic Survey Publication V-25, p. 103-108.

Gottschling, J., 2007, Appalachian Basin black shale exploitation: past, present, and future: presentation IOGA of PA annual meeting, May, 2007, 49 p. http://www.wvsoro.org/resources/marcellus/John_Gott_Marcellus\%20Shale.pdf, accessed August 2010.

Harper, J.A., 2008, The Marcellus Shale—an old “new” gas reservoir in Pennsylvania: Pennsylvania Geology, v. 38, p. 2-13, http://www.denr.state.pa.us/topogeo/pub/pageolmag/pdfs/v38n1.pdf, accessed December 2010.

Helland-Hansen, W. and Martinsen, O.J., 1996, Conceptual basis and variability in sequence stratigraphy: a different perspective. Sedimentary Geology, 92, 31-52.

Hill, D.G., Lombardie T.E., Martin, J.P., 2002, Fractured shale gas potential in New York: http://www.pe.tamu.edu/wattenbarger/public_html/Selected_papers/-- 
Shale $\% 20$ Gas/fractured $\% 20$ shale $\% 20$ gas $\% 20$ potential $\% 20$ in $\% 20$ new $\% 20$ york.pdf, accessded December 2010.

Jarvie, D., 2011, Worldwide Shale Resource Plays and Potential: Search and Discovery Article \#80144, http://www.searchanddiscovery.com/documents/2011/80144jarvie/ndx_jarvie.pdf, accessed June 2011.

Kuuskraa, V.A., and Wicks, D.E., 1984, Technically recoverable Devonian shale gas in West Virginia: DOE/MC/19239-1750 (DE85003367), December 1984, 119 p.

Lash, G.G., 2007, Influence of basin dynamics on Upper Devonian black shale deposition, western New York State and northwest Pennsylvania: Search and Discovery Article \#30050, http://www.searchanddiscovery.com/documents/2007/07022lash/index.htm, accessed May 2010.

Lash, G.G., Engelder, T., 2009, The Middle Devonian Marcellus Shale- a Record of Eustacy and Basin Dynamics: Search and Discovery Article \#30104, http://www.searchanddiscovery.net/documents/2009/090805lash/ndx_lash.pdf, accessed December 2010 .

Lash, G.G., Blood, R. 2011, Sequence Stratigraphy and its Bearing on Reservoir Characteristics of Shale Successions - Examples from the Appalachian Basin: Search and Discovery \#40708 http://www.searchanddiscovery.com/documents/2011/40708lash/ndx_lash.pdf, accessed June 2011

Martin, J.P., Hill, D.J., Lombardi, T.E., Nyahay, R.G., A Primer on New York’s Gas Shales. http://offices.colgate.edu/bselleck/AppBasin/GasshaleMartin.pdf, accessed December 2010.

Mazzullo, S.J., 1973, Deltaic depositional environments in the Hamilton Group (middle Devonian), southeastern New York State: Journal of Sedimentary Research, v. 43, p. 1061-1071.

Milici, R.C., Ryder, R.T., Swezey, C.S., Charpentier, R.R., Cook, T.A., Crovelli, R.A., Klett, T.R., Pollastro, R.M., and Schenk, C.J., 2003, Assessment of undiscovered oil and gas resources of the Applachian Basin province, 2002: United States Geological Survey Fact Sheet FS-009-03. 2 p. http://pubs.usgs.gov/fs/fs-00903/FS-009-03-508.pdf, accessed May 2010.

Murphy,A.E., Sageman,B.B, Hollander,D.J., Lyons,T.W., Brett,C.E., June 2000, Black Shale Deposition and Faunal Overturn in the Devonian Appalachian Basin: Clastic Starvation, Seasonal Water-Column Mixing, and Efficient Biolimiting nutrient Recycling: Paleoceanography, v. 15, p. 280-291. 
Myers, R., 2008, Marcellus Shale Update!: BJ Services Company 78 p.

http://www.iogawv.com/RRMShaleUpdate2.pdf, accessed December 2010

Neal, D., 1979, Subsurface Stratigraphy of the Middle and Upper Devonian Clastic Sequence in

Southern West Virginia and its Relation to Gas Production:

http://www.netl.doe.gov/kmd/cds/disk41/B\%20-

\%20Reservoir\%20Characterization/Subsurface\%20Stratigraphy\%20of\%20the \%20Middle $\% 20 \& \% 20$

Upper\%20Devonian.pdf, 139 p. Accessed Oct 2012

Nuttall, B.C., Drahovzal, J.A., Eble, C., Bustin, M.R., 2005, $\mathrm{CO}_{2}$ Sequestration in Gas Shales of Kentucky: Search and Discovery Article \#40171. http://www.searchanddiscovery.com/documents/2005/nutall/, accessed December 2010

Perry, C., Wickstrom, L., Oct. 2010, The Marcellus Shale Play: Geology, History, and Oil and Gas Potential in Ohio: Ohio Division of Natural Resources Geological Survey 38p. http://www.dnr.state.oh.us/Portals/10/Energy/Marcellus/The_Marcellus_Shale_Play_Wickstorm_and _Perry.pdf, accessed October 2010.

Piotrowski, R.G., Harper, J.A., 1979, Black Shale and Sandstone Facies of the Devonian “Catskill” Clastic Wedge in the Subsurface of Western Pennsylvania: EGSP Series No. 13, 42p. http://www.dcnr.state.pa.us/topogeo/oilandgas/EGSP_13_Text.pdf, Accessed December 2010

Prave, A.R., Duke, W.L., and Slattery, W., 1996, A depositional model for storm- and tide-influenced prograding siliciclastic shorelines from the Middle Devonian of the central Appalachian foreland ramp basin USA: Sedimentology, p. 611-629.

Reeves, J.R., and Davie, N.C., 1937, Subsurface Distribution of Hamilton Group of New York and Northern Pennsylvania: Bulletin of the American Association of Petroleum Geologists V-21. No. 3 march, 1937, p. 311-316

Repetski, J.E., Ryder, R.T., Avary, K.L., and Trippi, M.H., 2005, Thermal maturity patterns (CAI and \%Ro) in the Ordovician and Devonian rocks of the Appalachian basin in West Virginia: U.S. Geological Survey OpenFile Report 2005-1078, 72 p.

Roen, J.B., 1984, Geology of the Devonian black shales of the Appalachian basin: Organic Geochemistry, v. 5, p. 241-254. 
http://www.eesi.psu.edu/news_events/EarthTalks/2009Spring/materials2009spr/Roen84BlkShDevorggeoch .pdf, accessed December 2010 .

Sageman, B.B., Murphy, A.E., Werne, J.P, Ver Straeten,C.A., Hollander,D.J., Lyons, T.W., 2003, A tale of shales: the relative roles of production, decomposition, and dilution in the accumulation of organic-rich strata, Middle-Upper Devonian, Appalachain basin: Chemical Geology, v. 195, p. 229-273. http://www.earth.northwestern.edu/research/sageman/PDF/03.Sageman_etal.pdf, accessed January 2011.

Schwietering, J.F., 1981, The occurrence of oil and gas in Devonian shales and equivalents in West Virginia: U.S. Department Energy Unconventional Gas Resource Programs 1976-1995, Report DOE/ET/12130-T13, 38 p.

Smith, T., Leone, J., 2010, Utica and Marcellus Shale Potential in New York State: New York State Museum, 35 p. http://esogis.nysm.nysed.gov/esogisdata/downloads/talks/Smith_1130_Weds_AAPG_Shale.pdf, accessed January 2011.

Southworth, C.S., 1891, Cross-Strike Discontinuities and Lineaments of the Central Appalachians, Miscellaneous Field Studies, Map M?-1891 Pamphlet, 14 p.

Streib, D.L., 1980, Eastern Gas Shales Project Outgassing Analysis- Special Report: DOE METC/CR-80/2, Feb. 1980.

Unconventional Gas Center, 2009, Unconventional Natural Gas Report October 2009: Hart Energy publishing, No. 34-4, http://www.ugcenter.com/Library/HartUNGROct4NewsFinal.pdf, Accessed December 2010.

U.S. Department of the Interior, U.S. Geological Survey., 2003, Valley and Ridge Province. http://3dparks.wr.usgs.gov/nyc/valleyandridge/valleyandridge.htm, accessed December 2009.

Van Tyne, M., 1996, Middle Devonian Onondaga Limestone Reef Play: Upper Devonian black shales, in Roen, J.B., and Walker, B.J., eds., The atlas of major Appalachian gas plays: West Virginia Geological and Economic Survey Publication V-25, p. 100-102.

Ver Straeten, C.A., 2004, K-bentonites, volcanic ash preservation, and implications for Early to Middle Devonian volcanism in the Acadian orogen, eastern North America: Geological Society of America: Geological Society of America Bulletin v.116. no.3-4. P. 474-489.

Walker-Milani, M.E., 2011 Outcrop Lithostratigraphy and Petrophysics of the Middle Devonian Marcellus Shale in West Virginia and Adjacent States: MS thesis. West Virginia University. Morgantown, 2011. Print 
Werne, J.P., Sageman, B.B., Lyons, T.W., Hollander, D.J., 2002, An Integrated Assessment of a "Type Euxinic" Deposit: Evidence for Multiple Controls on Black Shale Deposition in the Middle Devonian Oatka Creek Formation: American Journal of Science, V. 302, Feb. 2002, p. 110-143.

Wrightstone, G., 2008, Marcellus Shale geologic controls on production: presentation, American Association Petroleum Geologists Eastern Section meeting, Pittsburgh, PA, 49 p.

Wrightstone, G., 2010, Bloomin'Algae! How Paleogeography and algal blooms may have significantly impacted deposition and preservation of the Marcellus Shale: Pittsburgh Association of Petroleum Geologists. http://www.papgrocks.org/Bloomin\%20Algae.pdf, accessed September 2010

Wrightstone, G., 2011 June, The Marcellus Experience: SPE Applied Technology Workshop. http://thepacoalition.com/wp-content/uploads/2011/06/The-Marcellus-Experience-Part-11.pdf, accessed June 2011

Zaengle, D., 2008, Welcome to the Tioga Gas Lease!: Tioga County Landowners Group. http://www.tiogagaslease.org/landforlease.html, accessed December 2010.

Zagorski, W.A., Wrightstone, G.A., and Bowman, D.C., 2012, The Appalachian Basin Marcellus gas play: Its history of development, geologic controls on production, and future potential as a world-class reservoir: J.A. Breyer, ed., Shale reservoirs - Giant resources for the $21^{\text {st }}$ century: AAPG Memoir 97, p. 172-200. 